JANAINA BALTHAZAR

\title{
AVALIAÇÃO DA MEMÓRIA E DAS CARACTERÍSTICAS NEUROPATOLÓGICAS DA DOENÇA DE ALZHEIMER, EM UM MODELO EXPERIMENTAL, APÓS ESTÍMULAÇÃO EM AMBIENTE ENRIQUECIDO
}

Dissertação apresentada ao Programa de PósGraduação em Farmacologia do Instituto de Ciências Biomédicas da Universidade de São Paulo, para obtenção do Título de Mestre em Ciências. 


\section{AVALIAÇÃO DA MEMÓRIA E DAS CARACTERÍSTICAS NEUROPATOLÓGICAS DA DOENÇA DE ALZHEIMER, EM UM MODELO EXPERIMENTAL, APÓS ESTIMULAÇÃO EM AMBIENTE ENRIQUECIDO}

Dissertação apresentada ao Departamento de Farmacologia do Instituto de Ciências Biomédicas da Universidade de São Paulo, para obtenção do Título de Mestre em Ciências.

Área de concentração: Farmacologia

Orientadora: Dra. Tânia Araújo Viel

Versão corrigida. A versão original eletrônica encontra-se disponível tanto na Biblioteca do ICB quanto na Biblioteca Digital de Teses e Dissertações da USP (BDTD). 
DADOS DE CATALOGAÇÃO NA PUBLICAÇÃO (CIP)

Serviço de Biblioteca e Informação Biomédica do Instituto de Ciências Biomédicas da Universidade de São Paulo

reprodução não autorizada pelo autor

Balthazar, Janaina.

Avaliação da memória e das características neuropatológicas da doença de Alzheimer, em um modelo experimental, após estimulação em ambiente enriquecido / Janaina Balthazar. -- São Paulo, 2013.

Orientador: Profa. Dra. Tânia Araújo Viel.

Dissertação (Mestrado) - Universidade de São Paulo. Instituto de Ciências Biomédicas. Departamento de Farmacologia. Área de concentração: Farmacologia. Linha de pesquisa: Estratégias não farmacológicas para a melhora da função cognitiva.

Versão do título para o inglês: Evaluation of memory and neuropathological hallmarks of Alzheimer's disease, in an experimental model, after stimulation in an enriched environment.

1. Doença de Alzheimer 2. Memórias 3. Hipocampo I. Viel, Profa. Dra. Tânia Araújo II. Universidade de São Paulo. Instituto de Ciências Biomédicas. Programa de Pós-Graduação em Farmacologia III. Título. 
Candidato(a):

Janaina Balthazar.

Título da

Avaliação da memória e das características neuropatológicas da doença de Alzheimer, em um modelo experimental, após estimulação em ambiente enriquecido.

Orientador(a): $\quad$ Profa. Dra. Tânia Araújo Viel.

A Comissão Julgadora dos trabalhos de Defesa da Dissertação de Mestrado, em sessão pública realizada a considerou
( ) Aprovado(a)
( ) Reprovado(a)

Examinador(a): Assinatura:

Nome:

Instituição:

Examinador(a): Assinatura:

Nome:

Instituição:

Presidente: Assinatura:

Nome:

Instituição: 


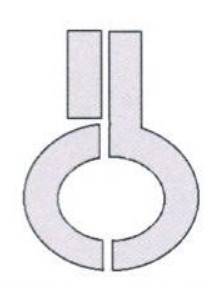

\section{UNIVERSIDADE DE SÃO PAULO \\ INSTITUTO DE CIÊNCIAS BIOMÉDICAS}

Cidade Universitária "Armando de Salles Oliveira"

Av. Prof. Lineu Prestes, 2415 - CEP. 05508-000 São Paulo, SP Brasil

Telefone :(55) (011) 3091.7733 - e-mail: cep@icb.usp.br

\section{Certificado}

Certificamos que o protocolo registrado sob $\mathrm{n}^{\circ} \mathbf{0 1 3}$ nas fls. 99 do livro 02 para uso de animais em experimentação, sob a responsabilidade do Prof(a) Dr(a)) Tania Araujo Viel, Coordenador(a) da Linha de pesquisa "Avaliação da características neuropatológicas da doença de Alzheimer, em um modelo experimental, após estímulo cognitivo" do qual participam o(s) alunos Janaina Balthazar e os pesquisadores Cristóforo Scavone, Hudson Buck, está de acordo com os Princípios Éticos de Experimentação Animal adotado pela Sociedade Brasileira de Ciência de Animaïs de Laboratório (SBCAL) e foi aprovado pela COMISSÃO DE ÉTICA NO USO DE ANIMAIS (CEUA) em 15.02.2011, com validade de 3 anos.

São Paulo, 17 de fevereiro de 2011.
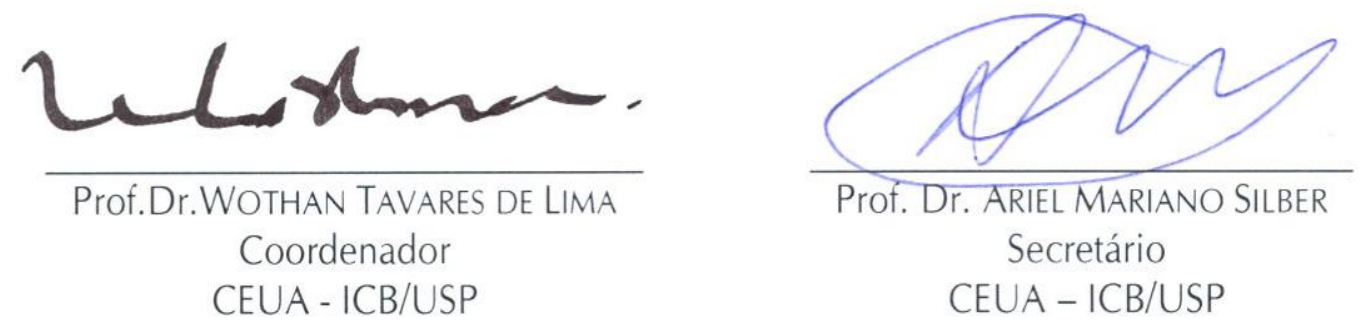
Dedico este trabalho...

Primeiramente a todos aqueles que sofrem da doença de Alzheimer; àqueles que nos momentos de desespero e esquecimento se sentem sós e desamparados por familiares que preferem ignorar a doença; àqueles que, mesmo tendo o apoio e o carinho da família, lutam contra uma doença degenerativa e "sem volta".

A todos aqueles que me cercaram e me ajudaram a realizar este trabalho, cujo intuito é cooperar para uma futura cura a tal doença.

Em especial a Deus e aos meus pais, José Narciso Balthazar (in memoriam) e Maria Ap. Nunes Balthazar que lutaram para criar seus filhos, abnegando suas vidas em nome de um Amor maior.

A minha avó, Rita Cassolatti Balthazar (in memoriam) que nos fez conhecer e mergulhar no misterioso e obscuro mundo da doença de Alzheimer.

A toda minha família, marido, irmãos, cunhadas e sobrinhos pela paciência, contribuição, carinho e companheirismo em todos os momentos. 


\section{AGRADECIMENTOS}

Primeiramente a Santíssima Trindade pelo sustento, força e capacitação. Pois muitos são chamados, mas poucos os escolhidos.

À Virgem Maria, mãe e sempre consoladora, pelo colo materno nas horas de angústia, medo e desânimo.

Ao meu tripé de sustentação São Miguel Arcanjo, Santa Teresinha e Santo Antônio.

Aos meus pais José Narciso Balthazar (in memoriam) e Maria Ap. Nunes Balthazar por darem seu sim a Deus e possibilitar que hoje eu esteja aqui. Por todos os ensinamentos, broncas e elogios fazendo de mim quem hoje eu sou. A vocês o meu Amor eterno!

Aos meus irmãos José Narciso Balthazar Junior e Juliano Balthazar pelo companheirismo, amizade e união indissolúvel. Por acreditarem no meu potencial e sempre me estimularem a ir além.

Ao meu marido Otávio Roberto Lourenção Junior pela paciência, companheirismo, horas de sono perdida e ombro amigo. Por sempre acreditar em mim e no meu potencial e aceitar dividir sua vida comigo. O meu muito obrigado por ser simplesmente quem você é.

Às minhas cunhadas Daniela Daudt Balthazar e Flávia Borges Balthazar pela amizade, carinho e companheirismo. E principalmente o meu muito obrigado por colocarem no mundo as coisas mais ricas e preciosas que tenho hoje, os meus sobrinhos Igor Daudt Balthazar, Eduardo Borges Balthazar e Gabriel Daudt Balthazar. A vocês, meus amores, o meu eterno colo de tia.

À minha prima Andreia Nunes pela grande amizade, pelo colo nos momentos difíceis e pelo Amor compartilhado a cada dia. Obrigada por ser minha amiga. 
À minha orientadora e sempre amiga Profa. Dra. Tânia Araújo Viel por toda paciência e dedicação. Por estar sempre perto e me ajudar a crescer cientificamente e como pessoa. Por ter me aceitado em seu grupo e depositado sua confiança como primeira aluna de mestrado, realizando, com isso, meu sonho. O meu muito obrigado eternamente!

Ao Prof. Dr. Hudson de Sousa Buck por todos os ensinamentos como pai científico, por ceder o espaço em seu laboratório para que pudesse realizar este trabalho e por sempre estar por perto e disponível nos momentos de dúvida. O meu grande carinho por você sempre!

À família Viel e Buck por fazerem parte hoje da minha vida.

À Natália Schöwe pela colaboração, dedicação e empenho para com a primeira etapa deste trabalho.

Ao Prof. Dr. Cristóforo Scavone pelo primeiro contato e acolhimento dentro do departamento de Farmacologia do Instituto de Ciências Biomédicas (ICB) e por me apresentar as pessoas maravilhosas que hoje fazem parte da minha vida.

À Profa. Dra. Carolina Munhoz pelo apoio e dedicação durante o estágio PAE.

À FCMSCSP, ao ICB e à EACH pela oportunidade de utilizar seus espaços e conviver com pessoas e professores de grande competência e força de vontade.

Ao Departamento de Ciências Fisiológicas da FCMSCSP por abrir as portas de seus laboratórios e disponibilizar seus funcionários e colaboradores para que este trabalho pudesse ser realizado.

Ao Sr. Martinho de Castro pelo carinho, cuidado e atenção para com nossos animais e sempre estar disponível para nos ajudar no biotério. 
Aos amigos do laboratório e integrantes do GPNF: Karla C. Monteiro-Silva, Ariadiny de Lima Caetano, Káris Dong, Ticiana Baraldi, Suzzanna Ingrid Souza, Marielza Nunes, Marília Albuquerque, Milena Telles, Viviane Bressani, Laura Coelho e Luiz Phellipe por estarem sempre disponíveis para me ajudar e colaborarem muito para minha formação científica, principalmente em nossas rodas de discussões e me proporcionar deliciosos momentos de descontração.

À Célia Nascimento, secretária do departamento de Ciências Fisiológicas da FCMSCSP e Mônica Nunes e Camila Trindade, secretárias do departamento de Farmacologia do ICB pela paciência e atenção nos momentos de dúvidas.

A CAPES e FAPESP pelo auxilio financeiro.

Obrigada a todos! 


\section{Oração a São Miguel Arcanjo}

Gloriosíssimo São Miguel, chefe e príncipe dos exércitos celestes, fiel guardião das almas, vencedor dos espiritos rebeldes, amado da casa de

Deus, nosso admirável guía depoís de Cristo, vós cuja excelência e virtude são eminentissimas, dignai-Vos livrar-nos de todos os males, nós todos que recorremos a vós com confíança, e fazei, pela vossa incomparável proteção, que adiantemos cada dia mais na fídelidade e perseverança em servir a Deus.

\section{Oração a Santa Teresinha}

Ensinai-nos, ó Santa Mestra, Doutora da Igreja, o caminho da santidade que nasce da escuta da Palavra de Deus, da realização de coísas simples e sem importâncía aos olhos do mundo.

Ajudai-me a crer diariamente no amparo de Deus sobre minha vida quando estou aflito, quando estou ansioso, quando estou enfermo, quando me sinto fraco e desencorajado para orar, trabalhar e Amar. Conceda-me o dom da alegria, a capacidade de sorrír e crer, mesmo quando houver escuridão dentro de mim. Fizestes do Amor o objetivo e sentido de vossa Greve vida. Enfrentaste com um sorriso todas as provações e nada negastes ao Bom Deus. Que Jesus, vosso Amado Esposo, esteja sempre comigo e com as pessoas que $\mathcal{A} m o$. 
"Somos o que Cembramos - e também aquílo que não queremos Cembrar."

"Cada um de nós é quem é porque tem suas próprias memórias."

"... em boa parte esquecemos para podermos pensar e esquecemos para não ficarmos loucos. Esquecemos para podermos conviver $e$ sobreviver."

"Noão há fórmulas para a felicidade. Talvez haja para o bem estar; a arte de esquecer, bem praticada, é uma delas."

Iván Izquierdo 


\section{RESUMO}

Balthazar J. Avaliação da memória e das características neuropatológicas da doença de Alzheimer, em um modelo experimental, após estímulação em ambiente enriquecido. [dissertação (Mestrado em Farmacologia)]. São Paulo: Instituto de Ciências Biomédicas, Universidade de São Paulo; 2013.

A doença de Alzheimer (DA) é uma doença progressiva, onde ocorre a destruição da comunicação neuronal, levando o paciente à perda de funções cognitivas. Sabe-se que o enriquecimento ambiental promove alterações morfológicas e funcionais no encéfalo, levando a amplificação das funções cognitivas, já descrita em humanos e animais. Neste trabalho, foram avaliados os efeitos da estimulação em ambiente enriquecido (AE) para a memória e para os marcadores neuropatológicos da DA em camundongos transgênicos (TG) que superexpressam a proteína precursora amilóide, PDGFB - APPSwInd e animais C57BI6 (WT), em duas idades, 7 e 12 meses de idade, estimulados durante quatro meses. Foram avaliadas a memória espacial, em labirinto de Barnes, e a memória relacionada a estímulo aversivo, em esquiva inibitória. Após as observações comportamentais, foram realizados estudos histológicos para avaliação da densidade dos terminais pré-sinápticos e corpos neuronais, hiperfosforilação da Tau e contagem de placas senis. Nos animais TG ou WT, estimulados dos 3 aos 7 meses de idade, o AE aparentemente promoveu um melhor funcionamento dos circuitos neuronais, sem alteração da densidade dos terminais présinápticos e dos corpos neuronais, pois esses animais foram capazes de armazenar a informação relacionada ao estímulo aversivo por até 2 meses. Nessa idade não foi observada diferença na memória espacial entre os grupos avaliados. Nos grupos de animais observados dos 8 aos 12 meses de idade, os animais TG que passaram em ambiente enriquecido apresentaram uma redução de $85,18 \%$ no valor total de placas na região dorsal do hipocampo quando comparados ao grupo TG controle. Porém, não foram observadas diferenças estatisticamente significativas nos testes de memória e avaliações histológicas, entre os grupos, provavelmente devido ao baixo número de animais em cada grupo. No modelo animal utilizado, não foi possível identificar a formação de novelos neurofibrilares, aos 12 meses de idade, com os métodos utilizados. Diante das observações realizadas nesse trabalho, podemos inferir que a manutenção de animais em ambiente enriquecido gera alterações no sistema nervoso central que constituem melhorias funcionais, protetoras no caso da presença de doenças neurodegenerativas como a DA. Com o presente trabalho não foi possível verificar os mecanismos pelos quais essas melhorias são estabelecidas, porém é fato que contribuem com as reservas cognitivas verificadas tanto em humanos quanto em animais, após estimulação cognitiva e/ou física.

Palavras-chave: Doença de Alzheimer. Ambiente Enriquecido. Memória. Hipocampo. 


\begin{abstract}
Balthazar J. Evaluation of memory and neuropathological hallmarks of Alzheimer's disease in an experimental model after stimulation in an enriched environment. [Masters thesis (Pharmacology)]. São Paulo: Instituto de Ciências Biomédicas, Universidade de São Paulo; 2013.

Alzheimer's Disease $(A D)$ is a progressive disease, where the destruction of neuronal circuitry leads to loss of cognitive functions. It is already known that stimulation in enriched environment (EE) promotes morphological and functional changes in the brain, leading to amplification of cognitive functions, as described in humans and animals. In this study, we evaluated the effects of EE stimulation for the memory and neuropathological hallmarks of $A D$ in transgenic mice (TG) that overexpress amyloid precursor protein, PDGFB-APPSwInd and $\mathrm{C} 57 \mathrm{BI} / 6$ animals (WT), in two ages, 7 and 12 months of age, stimulated during 4 months. Barnes maze was used to evaluate spatial memory, while inhibitory avoidance apparatus was used to evaluate aversive memory. After the behavioural studies, histological analysis were conducted to evaluate neuronal bodies, presynaptic terminals, tau hyperphosphorylation and density of senile plaques. In TG or WT animals, stimulated from 3 to 7 months of age, the EE apparently promoted a better functioning in the neuronal circuits, with no change in the density of presynaptic terminals and neuronal bodies, once these animals were capable of storing information related to the aversive stimulus for up to 2 months. At that age, all groups showed no difference in spatial memory. In the older group (8 to 12 months of age), TG animals stimulated in enriched environment showed a reduction of $85.18 \%$ in total density of senile plaques, in the dorsal region of the hippocampus, when compared to the TG control group. However, there weren't significant differences in memory and in the histological tests among the groups evaluated, probably due to few animals in each group. In this animal model it was not possible to identify the formation of neurofibrillary tangles, at 12 months of age, with the methods used. Taking all these data together, one may conclude that stimulation in environmental enrichment leads to changes in central nervous system that are protective in the presence of neurodegenerative diseases, as AD. In this work it was not possible to verify the mechanisms endowed in those improves, but they surely contribute to cognitive reserves observed in humans and animals, after cognitive and/or physical stimulation.
\end{abstract}

Keywords: Alzheimer's Disease. Enriched environment. Memory. Hippocampus 


\section{LISTA DE ILUSTRAÇÕES}

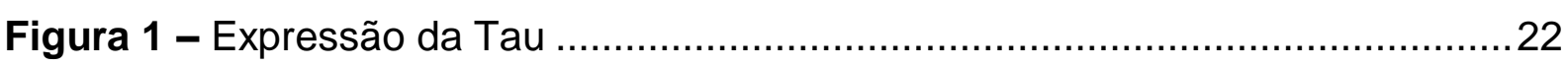

Figura 2 - Diagrama de circuito do hipocampo ………....................................25

Figura 3 - Diagrama do circuito do medo condicionado contextual ........................26

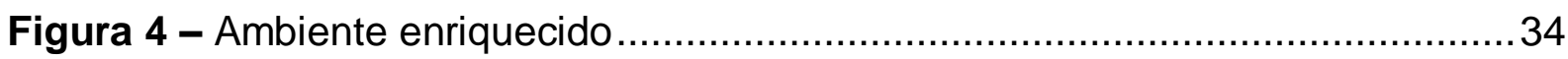

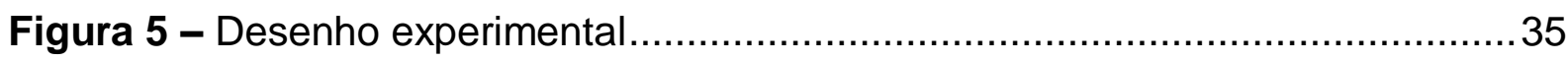

Figura 6 - Avaliação da deambulação dos animais WT e TG, aos 5 e 7 meses de

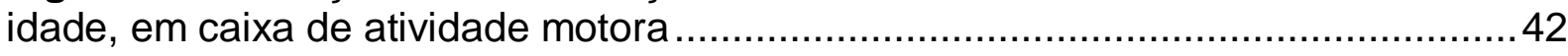

Figura 7 - Avaliação da deambulação dos animais WT e TG, aos 5 e 7 meses de idade, em caixa de atividade motora.

Figura 8 - Avaliação da latência para achar a caixa de escape dos animais WT e TG, aos 5 meses de idade, no labirinto de Barnes.

Figura 9 - Avaliação da latência para achar a caixa de escape dos animais WT e TG, aos 7 meses de idade, no labirinto de Barnes.

Figura 10 - Avaliação da memória relacionada ao estímulo aversivo dos animais WT e TG, aos 5 meses de idade, em esquiva inibitória - Sessão de Aquisição (SA) e Teste $24 \mathrm{~h}$ 46

Figura 11 - Avaliação da memória relacionada ao estímulo aversivo dos animais WT e TG, aos 7 meses de idade, em esquiva inibitória - Teste 24 h e Reteste1.

Figura 12 - Quantificação de terminais pré-sinápticos em regiões do hipocampo de animais WT e TG, aos 7 meses de idade, utilizando anticorpo anti-sinaptofisina ..... 48

Figura 13 - Quantificação de terminais pré-sinápticos no Córtex (A) e Amígdala (B) de animais WT e TG, aos 7 meses de idade, utilizando anticorpo anti-sinaptofisina 49

Figura 14 - Quantificação de corpos neuronais nas regiões PyCA1 (A) e GrDG (B) do hipocampo de animais WT e TG, aos 7 meses de idade, utilizando a coloração Cresil-violeta.

Figura 15 - Contagem de placas senis no hipocampo de animais WT e TG, aos 7 meses de idade, após coloração com Vermelho Congo

Figura 16 - Imagens representativas de cortes de cérebro de camundongos WT e TG, aos 7 meses de idade, corados com Cresil-violeta e Vermelho Congo..... 
Figura 17 - Avaliação da deambulação dos animais WT e TG, aos 8, 10 e 12 meses de idade, em caixa de atividade motora

Figura 18 - Avaliação da exploração vertical dos animais WT e TG, aos 8, 10 e 12 meses de idade, em caixa de atividade motora

Figura 19 - Avaliação da latência para achar a caixa de escape dos animais WT e TG, aos 12 meses de idade, no labirinto de Barnes

Figura 20 - Avaliação do número de erros cometidos pelos animais WT e TG para achar a caixa de escape, aos 12 meses de idade, no labirinto de Barnes.

Figura 21 - Avaliação da memória relacionada ao estímulo aversivo dos animais WT e TG, aos 12 meses de idade, em esquiva inibitória - Sessão de Aquisição (SA) e Teste $24 \mathrm{~h}$

Figura 22 - Avaliação da memória relacionada ao estímulo aversivo dos animais WT e TG, aos 12 meses de idade em esquiva inibitória - Teste 24 h e Teste 7 dias......60

Figura 23 - Quantificação de terminais pré-sinápticos em regiões do hipocampo, de animais WT e TG, aos 12 meses de idade, utilizando anticorpo anti-sinaptofisina ...61

Figura 24 - Quantificação de terminais pré-sinápticos no Córtex (A) e Amígdala (B) de animais WT e TG, aos 7 meses de idade, utilizando anticorpo anti-sinaptofisina 62

Figura 25 - Quantificação de corpos neuronais nas regiões PyCA1 (A) e GrDG (B) do hipocampo de animais WT e TG, aos 12 meses de idade, utilizando a coloração Cresil-violeta.

Figura 26 - Contagem de placas senis no hipocampo de animais WT e TG, aos 12 meses de idade, após coloração com Vermelho Congo .

Figura 27 - Imagens representativas de cortes de cérebro de camundongos WT e TG, aos 12 meses de idade, corados com Cresil-violeta e Vermelho Congo.

Figura 28-A - Imagens representativas de cortes do córtex de camundongos WT e TG, aos 12 meses de idade. Imunohistoquímica revelada com DAB para TAU-5 ....67

Figura 28-B - Imagens representativas de cortes do hipocampo de camundongos WT e TG, aos 12 meses de idade. Imunohistoquímica revelada com DAB para TAU5 .

Figura 29 - Imagens representativas de cortes do córtex e do hipocampo de camundongos WT e TG, aos 12 meses de idade. Imunofluorescência revelada com DAPI para TAU-5. 


\section{LISTA DE ABREVIATURAS E SIGLAS}

ABL - complexo da amígdala basoloateral

Ace - amígdala central

AE - ambiente enriquecido

$A L$ - amígdala lateral

AM - amígdala medial

BL - núcleo basolateral da amígadala

BM - núcleo basomedial da amígdala

CA1 e 3 - cornu ammonis, áreas 1 e 3

DA - doença de Alzheimer

DAB - 3,3'-Diaminobenzidine

DAPI - Diamidino-2-phenylindol

GrDG - camada granular do giro denteado

MEEM - mini exame do estado mental

MoDG - camada molecular do giro denteado

mRNA - ácido ribonucleico mensageiro

NMDA - N-methyl-D-aspartate

PBS - tampão fosfato-salina

PoDG - camada polimórfica do giro denteado

PPA - proteína precursora amilóide

PS1 - Presenilina 1

PS2 - Presenilina 2

PyCA1 - camada de células piramidais do CA1

RNA - ácido ribonucleico

ROD - densidade óptica relativa

SA - sessão de aquisição

sPPA $\beta$ - fragmento solúvel $\beta$ da proteína precursora amilóide

Syn - sinaptofisina

TG - transgênico

TG-AE - transgênico ambiente enriquecido

TG-Ctrl - transgênico controle

TMB - 3, 3', 5, 5'-Tetramethylbenzidine

W - watts 
WT - wild type

WT-AE - wild type ambiente enriquecido

WT-Ctrl - wild type controle

${ }^{\circ} \mathbf{C}$ - grau Celsius

$\beta$ - beta

h - hora

$\mathbf{m A}$ - miliampere

$\mu \mathrm{m}$ - micrômetro

min - minuto

P - rô

s- segundos 


\section{SUMÁRIO}

1 INTRODUÇÃO

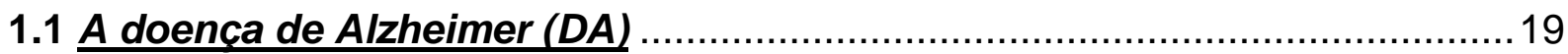

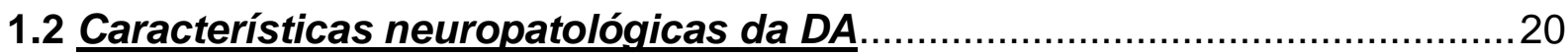

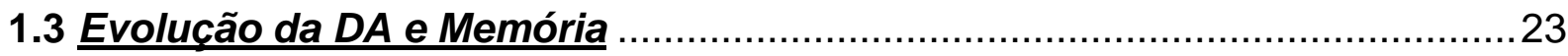

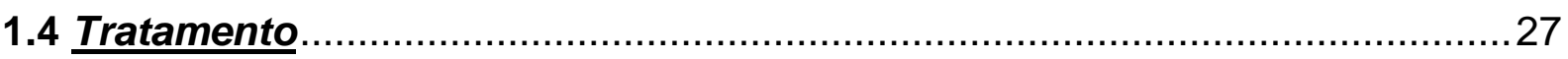

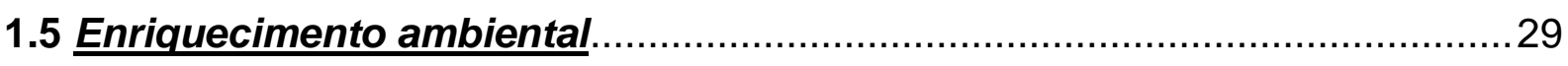

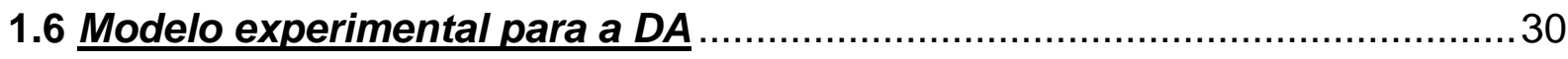

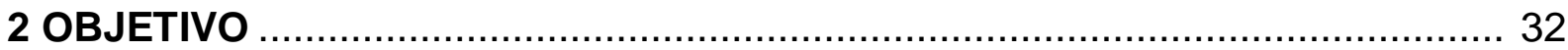

2.1 Objetivo geral

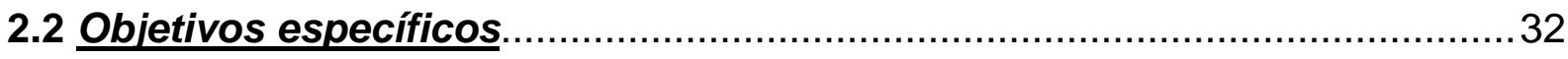

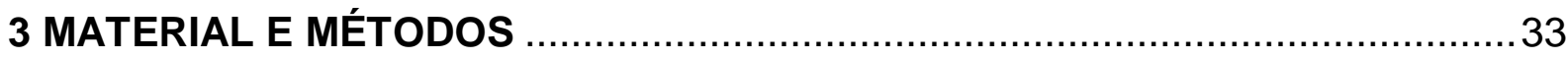

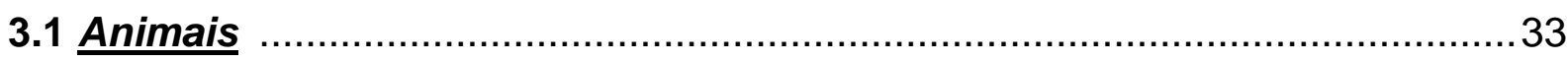

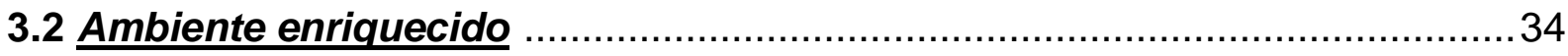

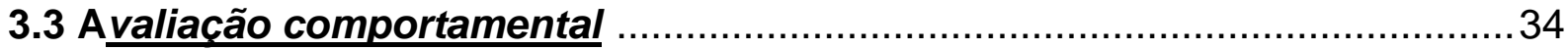

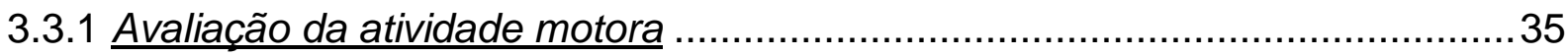

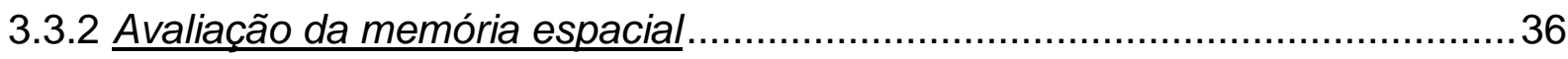

3.3.3 Avaliação da memória relacionada a estímulo aversivo...................................36

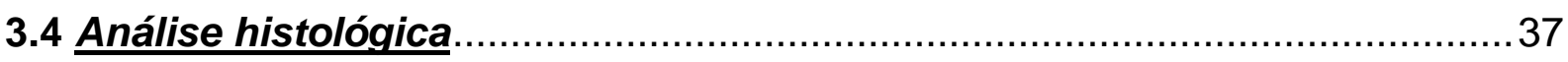

3.4.1 Análise das densidades de terminais pré-sinápticos .......................................37

3.4.2 Quantificação de placas $\beta$-amilóide e análise das densidades de corpos

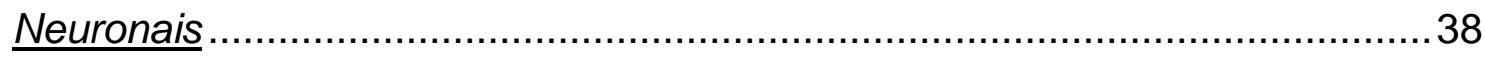

3.4.3 Identificação e análise de emaranhados neurofibrilares...................................39

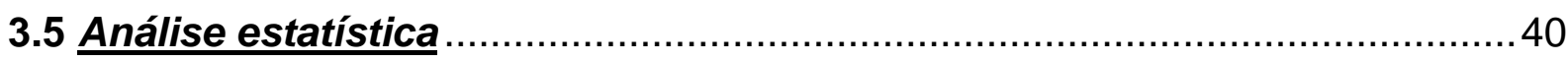

4 RESULTADOS

4.1 Estudo comportamental e histológico dos animais de 3 a 7 meses............. 42

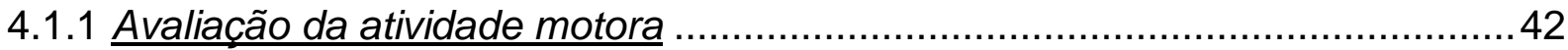

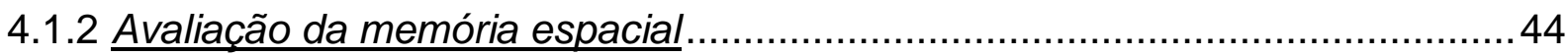

4.1.3 Avaliação da memória relacionada a estímulo aversivo..................................46

4.1.4 Quantificação das imunomarcações para Sinaptofisina ..................................48

4.1.5 Análise da densidade de corpos neuronais................................................. 50

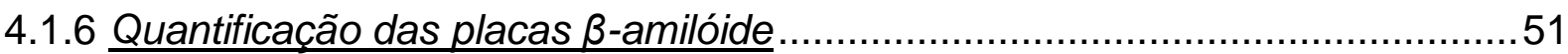


4.2 Estudo comportamental e histológico dos animais de 8 a 12 meses...........54

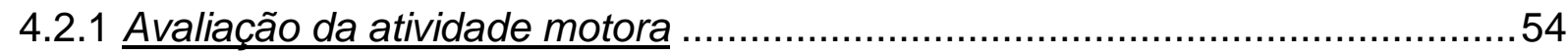

4.2.2 Avaliação da memória espacial ........................................................... 56

4.2.3 Avaliação da memória relacionada a estímulo aversivo.................................59

4.2.4 Quantificação das imunomarcações para Sinaptofisina ..................................61

4.2.5 Análise da densidade de corpos neuronais................................................63

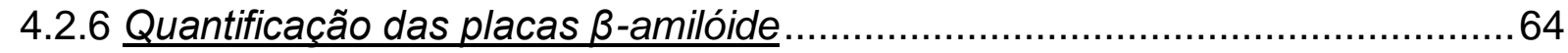

4.2.7 Identificação e análise de emaranhados neurofibrilares.................................67

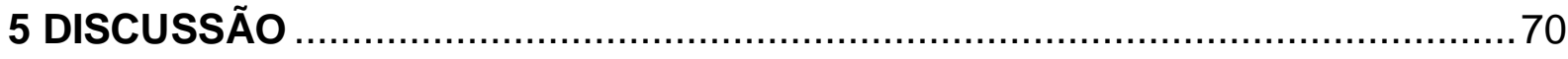

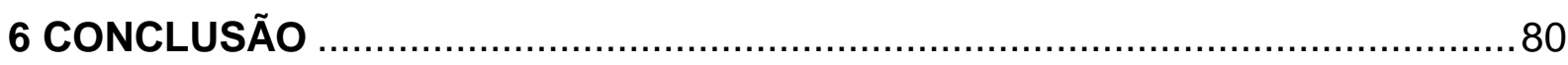

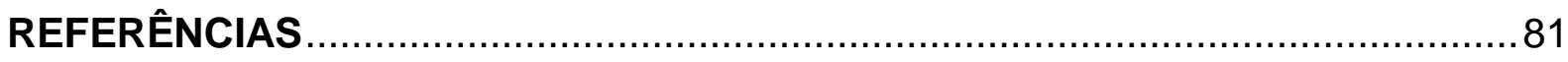




\section{INTRODUÇÃO}

\subsection{A doenca de Alzheimer (DA)}

Em 1906, analisando amostras de tecido cerebral de uma paciente, o médico alemão Alois Alzheimer projetou a hipótese de uma nova doença que afetaria o córtex cerebral levando a demência senil, com sintomas como déficit de memória, alterações de comportamento e incapacidade para as atividades rotineiras. Em 1911, Dr. Alzheimer publicou os resultados dos seus testes de histopatologia, onde mostrou a formação de novelos neurofibrilares e o acúmulo de placas características no espaço extracelular, nas amostras de sua paciente (Alzheimer's Association, 2011).

Hoje sabemos que a doença de Alzheimer (DA) é uma doença progressiva fatal, onde ocorre a destruição das células nervosas, principalmente a perda de neurônios colinérgicos no hipocampo e no córtex frontal, o que leva o paciente à perda de memória, mudanças de comportamento, perda da habilidade para cumprir suas atividades e perda do controle das funções fisiológicas (Alzheimer's Association, 2011; Mattson, 2004). Sua causa ainda é desconhecida.

Pesquisas realizadas pela Alzheimer's Association (2011) mostram que cerca de 5.2 milhões de americanos com 65 anos ou mais sofrem da DA. Cerca de 200.000 indivíduos abaixo dessa idade também apresentam os sintomas, sendo estes casos, em sua maioria, relacionados com o Alzheimer familiar, de início precoce e origem hereditária. A mesma fonte revela também que a DA vem subindo como causa de morte nos Estados Unidos (EUA), com uma incidência de 170 novos casos a cada 1000 pessoas entre 75 e 84 anos. Hoje, a doença é a sexta causa de morte no país, equiparando-se a outras como o câncer de próstata e mama, acidente vascular encefálico e doenças cardiovasculares (Alzheimer's Association, 2011).

No Brasil, em estudos realizados utilizando amostras de idosos de base comunitária, a prevalência de demência na população com mais dos 65 anos foi de $7,1 \%$, sendo que a DA foi responsável por $55 \%$ dos casos (Herrera et al., 2002). A taxa de incidência foi 7,7 por 1.000 pessoas/ano em estudo realizado no estado de São Paulo e 14,8 por 1.000 pessoas/ano em estudo no Rio Grande do Sul (Chaves et al., 2009; Nitrini et al., 2004). Considerando a prevalência de demência no Brasil e 
a população de idosos, aproximadamente 14 milhões, a estimativa em 2010 para demência era de 1,1 milhão (Brasil, 2010).

O fato mais preocupante em toda essa evolução é que os tratamentos farmacológicos até então existentes apenas são capazes de retardar a doença e amenizar alguns sintomas, mas não conseguem combatê-la. O tratamento mais utilizado atualmente é com os inibidores da colinesterase, como a donepezila e galantamina e com antagonistas do glutamato como a memantina (Hogan et al., 2008). É devido a este fato que a ciência vem buscando alternativas para melhorar a qualidade de vida desses pacientes.

\subsection{Características neuropatológicas da DA}

Os achados do Dr. Alzheimer, publicados em 1911, ainda hoje são os dois principais sinais microscópicos da DA e que culminam com a redução do volume cerebral.

As placas amilóides (placas senis) consistem em depósitos extracelulares do peptídeo $\beta$-amilóide, que contém cerca de 40 aminoácidos. O $\beta$-amilóide é derivado da proteína precursora amilóide (PPA). A PPA é composta de aproximadamente 770 aminoácidos, distribui-se amplamente por neurônios em cérebros normais e é expressa pelo cromossomo 21 (Haass, Selkoe, 2007; Kang et al., 1987). O processo amiloidogênico, onde ocorre à liberação do peptídeo $\beta$-amilóide, inicia-se quando a PPA sofre a ação da enzima $\beta$-secretase que a cliva no segmento $\mathrm{N}$-terminal de seu domínio $\beta$-amilóide, liberando o fragmento solúvel sPPA $\beta$ para o meio extracelular (Bossy-Wetzel et al., 2004; Haass, Selkoe, 2007; Suh, Checler, 2002).

O $\beta$-amilóide produzido pode permanecer em forma solúvel ou então agregarse, tornando-se insolúvel e depositando-se na forma de placas senis, que são patogênicas. Estudos recentes mostraram que a forma oligomérica do $\beta$-amilóide, que seria a solúvel, apresenta grande potencial neurotóxico e pode afetar de forma significativa diferentes vias de sinalização celular (Haass, Selkoe, 2007; Hsia et al., 1999; Pimplikar, 2009).

Os aglomerados neurofibrilares consistem no acúmulo intracelular de proteína Tau. Essa proteína faz parte da família das proteínas associadas aos microtúbulos, sua principal função é estabilizar os microtúbulos pela agregação da tubulina, 
controlando a dinâmica durante a maturação e o crescimento dos neurônios (Kikkawa et al., 1994). Em todos os tipos celulares, os microtúbulos correspondem a uma estrutura dinâmica, fundamental para o processo de divisão celular. Nos neurônios maduros essa função se perde e os microtúbulos especializam-se na manutenção da citoarquitetura e no transporte intraneural (Cleveland, Hoffman, 1991).

Em células sadias do cérebro, a Tau é uma proteína solúvel, apresentando-se em seis isoformas derivadas do splicing alternativo de mRNA (do inglês messenger Ribonucleic Acid) e compostas por 352-441 resíduos de aminoácidos. O splicing alternativo da Tau nos éxons 2, 3 e 10 resulta na presença dessas seis diferentes isoformas que contêm, respectivamente, nenhuma (sem éxon 2 e 3), uma (com éxon 2 e sem éxon 3) ou duas inserções (com éxon 2 e 3) no segmento amino terminal e três (sem éxon 10) ou quatro repetições (com éxon 10) do sítio de ligação ao microtúbulo no segmento carboxi terminal (Figura 1). A expressão das isoformas da Tau é regulada durante o desenvolvimento. A proteína Tau é normalmente encontrada nos axônios, mas em achados descritos em algumas doenças, a proteína encontra-se distribuída no corpo celular e nos dendritos (Avila et al., 2004; Goedert, 2004; Wang, Liu, 2008). 
Figura 1- Expressão da Tau

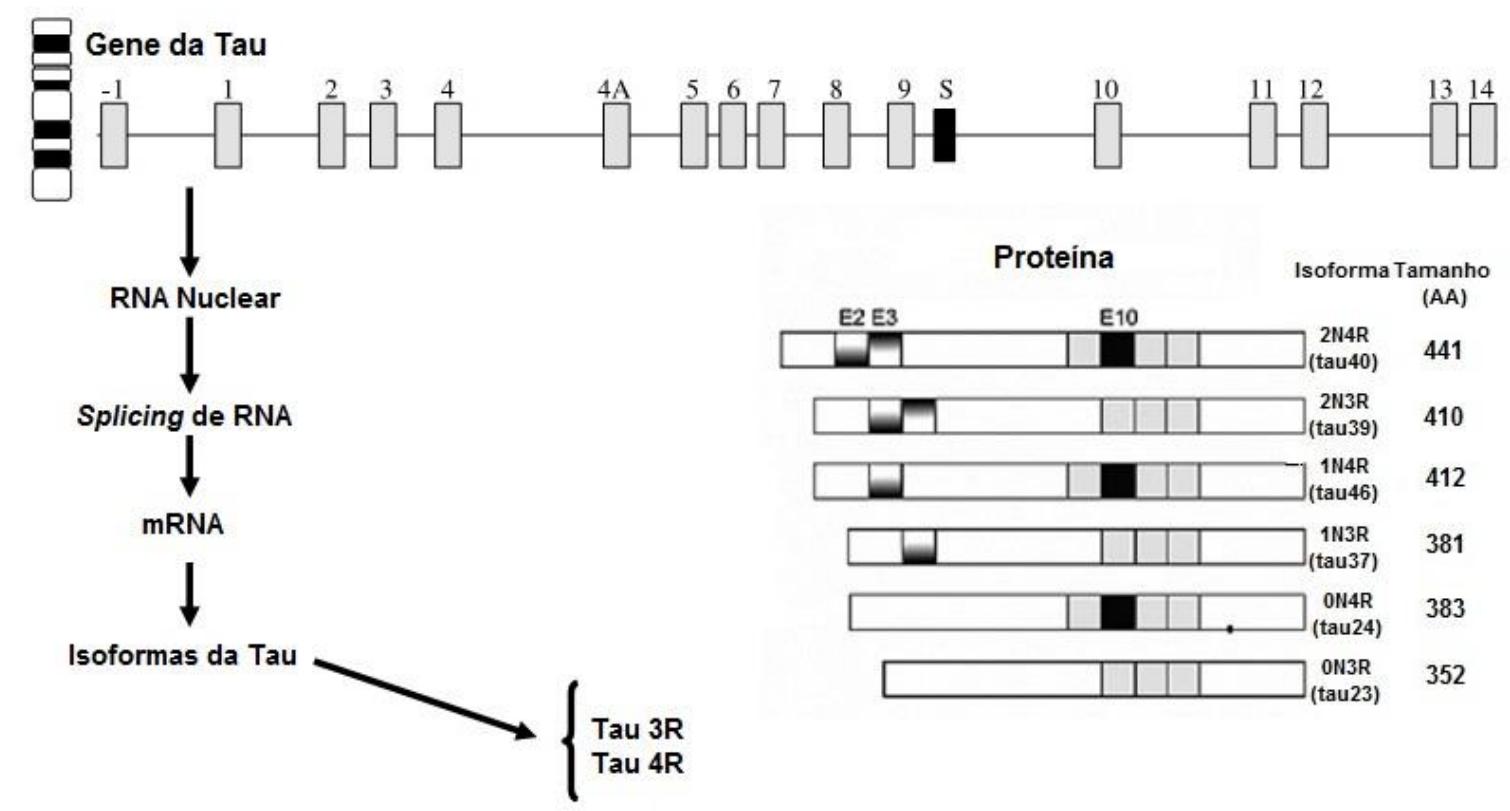

O gene da tau, localizado no cromossoma 17 humano é transcrito para o correspondente RNA que, após o splicing alternativo, origina vários mRNAs para tau. Estes mRNAs, após tradução, originam diferentes isoformas da tau. As diferentes isoformas da tau são nomeadas de acordo com os números de inserções da sequência $\mathrm{N}$-terminal e $\mathrm{C}$-terminal do domínio de ligação ao microtúbulo (por exemplo 2N4R) ou de acordo com os clones (por exemplo Tau40). O número de aminoácidos (AA) da proteína está ao lado direito de cada isoforma.

Fonte: Adaptado de Avila et al., 2004; Wang, Liu, 2008.

A proteína Tau pode ser encontrada na forma insolúvel nos filamentos helicoidais pareados, que é o principal componente dos emaranhados neurofibrilares. Esses filamentos apresentam de seis a oito grupos fosfato por molécula de proteína Tau, permitindo afirmar que a Tau encontra-se em estado hiperfosforilado. Em um cérebro sadio essa proporção costuma ser em torno de dois grupos por molécula (Brandt et al., 2005).

A hiperfosforilação da Tau presente no citosol, durante estágios iniciais de degeneração neurofibrilar induz mudanças conformacionais que precedem sua agregação. A Tau é a maior proteína do citoesqueleto e sua hiperfosforilação compromete o transporte axonal e o metabolismo das sinapses, causando disfunções que resultam em perda de viabilidade celular, colapso do citoesqueleto microtubular e morte neuronal (Wang, Liu, 2008).

Esses dois depósitos, placas $\beta$-amilóide e emaranhados neurofibrilares, são agregados proteicos que resultam do processamento não-usual das proteínas nativas. Aparecem, também, em cérebros não doentes, mas em menor número. Estudos correlacionam estes dois achados como principais causadores do déficit 
cognitivo apresentado pelos pacientes com DA (Brandt et al., 2005; Haass, Selkoe, 2007; Pimplikar, 2009; Wang, Liu, 2008; Wolf et al., 2006).

\subsection{Evolucão da DA e Memória}

Cada paciente de Alzheimer sofre a doença de forma diferenciada. Muitas vezes os primeiros sintomas são confundidos com problemas normais do envelhecimento ou estresse. Com o avançar da doença vão aparecendo sintomas como perda de memória, confusão mental, irritabilidade, agressividade, falhas na linguagem, dificuldades com as atividades da vida diária como alimentar-se e banhar-se e o paciente, então, desliga-se da realidade (American Psychiatry Association, 1994).

Antes de se tornar totalmente aparente, a DA desenvolve-se por um período indeterminado de tempo e pode manter-se não diagnosticada e assintomática durante anos. Quando a suspeita recai sobre a DA, o paciente é submetido a uma série de testes cognitivos, como o Mini Exame do Estado Mental (MEEM) e exames de neuroimagem para um diagnóstico de provável doença de Alzheimer, por exclusão de outras doenças senis (Associação Médica Brasileira et al., 2011; Nitrini, 2005). Um diagnóstico definitivo só pode ser realizado por necropsia com identificação do número apropriado de placas e novelos neurofibrilares em regiões específicas do cérebro, na presença de história clínica consistente com demência (Brasil, 2010).

As alterações cerebrais na DA ocorrem desde o início da doença, em estruturas do lobo temporal medial, incluindo o hipocampo e o giro para-hipocampal, consideradas estruturas essenciais para os processos de memória. Com a evolução da doença, o processo degenerativo se espalha para áreas corticais, atingindo áreas cerebrais responsáveis por outros processos cognitivos (Mattson, Magnus, 2006).

Com o lobo temporal medial afetado pela doença, o esquecimento se torna o primeiro e mais aparente sintoma da DA. Segundo James McGaugh, em livro publicado em 1971, "o aspecto mais notável da memória é o esquecimento" (Harlow et al., 1971). As memórias em geral são perdidas ao longo dos anos devido à falta de uso ou por desaparecimento das sinapses que a abrigavam em consequência de morte celular ou de perda dos prolongamentos sinápticos correspondentes, axônios 
ou dendritos (Izquierdo, 2010). Na DA, essa morte neuronal é exacerbada pelo próprio quadro da doença.

A memória é a capacidade de adquirir, armazenar e recuperar informações e está dividida em dois tipos principais. O primeiro tipo envolve a capacidade de verbalizar um fato (memória declarativa). O segundo envolve a capacidade de reter e processar uma informação que não pode ser verbalizada (memória de procedimento), como dirigir ou andar de bicicleta, esta última é um tipo de memória mais estável e mais difícil de ser perdida (Izquierdo, 2002; Kandel, 2009). No paciente de Alzheimer a perda da memória de procedimento acontece nos últimos estágios da doença (Satler, Tomaz, 2011).

A memória declarativa ainda pode ser subdividida em memória de curto prazo e longo prazo. A memória de curto prazo é aquela com duração de segundos ou minutos, onde há a formação dos traços de memória, este momento pode ser considerado um período de consolidação da informação, onde a memória é lábil, sensível e há a formação de novas proteínas, para transformação em memória de longo prazo com duração de dias, meses e anos (Izquierdo, 2002; Kandel, 2009). A perda da memória de curta duração é um dos sintomas iniciais da DA, enquanto a perda da memória de longa duração ocorre de maneira progressiva ao longo da evolução da doença (Parra et al., 2009).

Nesse trabalho foram avaliados dois tipos de memória, a espacial e a relacionada a estímulo aversivo. Essas memórias envolvem estruturas cerebrais como o córtex, o hipocampo e a amígdala, importantes para a formação, consolidação e recuperação desses tipos de memória e afetadas pela DA.

A memória espacial é um tipo de memória declarativa de curta ou longa duração. Ela envolve um mapa cognitivo, onde a estrutura central é o hipocampo (O’Keefe, Nadel, 1978). Estudos mostraram que lesões no hipocampo de ratos fizeram com que esses animais não conseguissem aprender ou recordar layouts espaciais, principalmente quando o hipocampo era lesionado em sua totalidade, pois quando essas lesões eram em regiões específicas a orientação espacial era prejudicada parcialmente (Martin et al., 2005; Morris et al., 1982). Quando lesionado o hipocampo em sua região ventral não se observou alterações significativas no processo da memória espacial, mas quando lesionada a região dorsal foi observados prejuízos na formação e recuperação da memória espacial de curto e longo prazo, mostrando assim funções distintas para essas duas regiões do 
hipocampo na memória espacial (Lee, Kesner, 2003; Moser et al., 1993; Moser, Moser 1998).

A memória e a capacidade de orientação espacial no hipocampo estão diretamente relacionadas com as chamadas "células de localização". Podemos encontrar essas células como piramidais nas regiões do cornu ammonis, áreas 1 e 3 (CA1 e CA3) e como granulares na região do giro denteado, sendo essas três regiões essenciais para esse tipo de memória (Brun et al., 2002; Goodrich-Hunsaker et al., 2008; O’Keefe, Nadel, 1978; Saab et al., 2009) (Figura 2).

Figura 2 - Diagrama de circuito do hipocampo

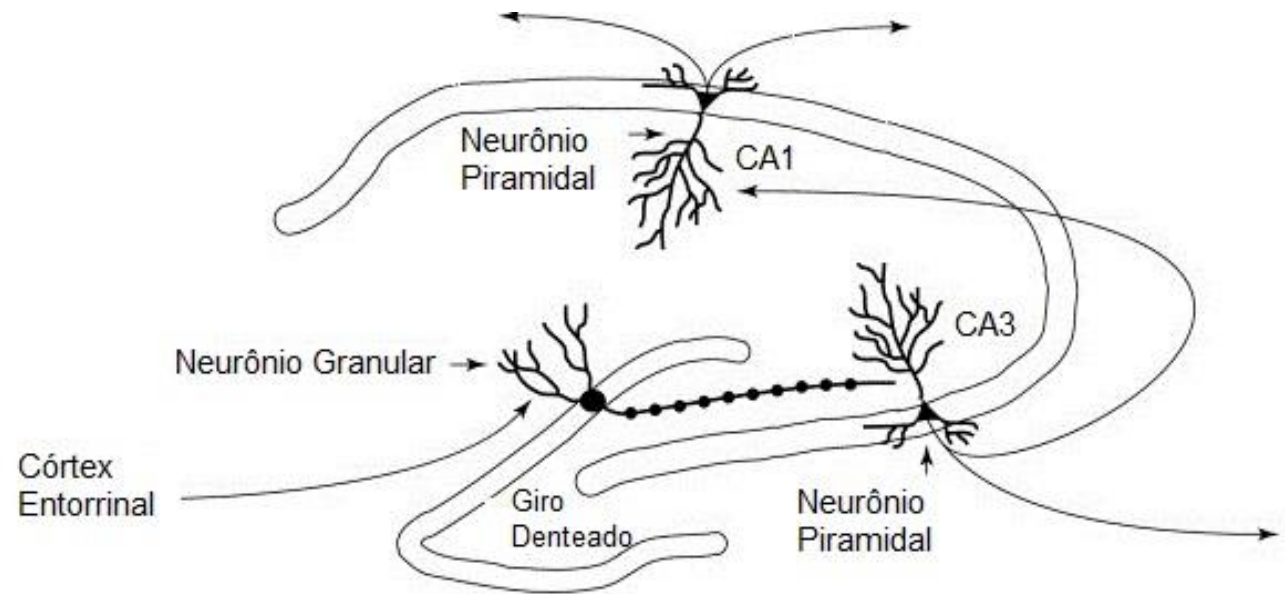

O giro denteado recebe a entrada de informações a partir do córtex entorrinal, através de seus neurônios granulares e envia projeções para a região $\mathrm{CA}$, de neurônios piramidais, que envia a sua projeção para os neurônios, também piramidais, do CA1.

Fonte: Adaptado de McEwen et al., 1999.

A memória relacionada ao estímulo aversivo, por outro lado, é um tipo de memória que envolve mecanismos de condicionamento de medo. Nesse caso, um organismo é treinado a prever um evento aversivo. A memória aversiva possui geralmente uma fase condicionada, com um estímulo neutro ou contextual e uma fase não condicionada, com um estímulo aversivo, onde é gerada uma resposta de medo ou resposta condicionada. O medo condicionado faz parte do condicionamento clássico, conhecido como condicionamento Pavloviano (Frendt, Fanselow, 1999; LeDoux, 2000; Maren, 2001).

Estudos mostraram que a falta do medo em animais estava relacionada a lesões no lobo temporal que afetavam a amígdala. A partir desses estudos um 
consenso é formado de que o complexo amigdaloide tem um papel indispensável na regulação do medo (Goddard, 1964; Meunier et al., 1999; Weiskrantz, 1956; ZolaMorgan et al., 1991).

A amígdala pode ser dividida em vários núcleos, amígdala lateral $(A L)$, núcleo basolateral (BL) e núcleo basomedial (BM) que juntos formam o complexo da amígdala basolateral ( $A B L)$, amígdala central ( $A C e)$ e amígdala medial ( $A M)$.

Quando se trata do circuito do medo condicionado, a $A B L$ recebe e integra informações sensoriais a partir de uma variedade de fontes, como o córtex préfrontal e o hipocampo (região do CA1). O hipocampo está envolvido principalmente quando a informação é espacial e contextual (Fredt, Fanselow, 1999; Kim, Fanselow, 1992; Maren, 2001; Phillips, LeDoux, 1992) (Figura 3).

Figura 3 - Diagrama do circuito do medo condicionado contextual

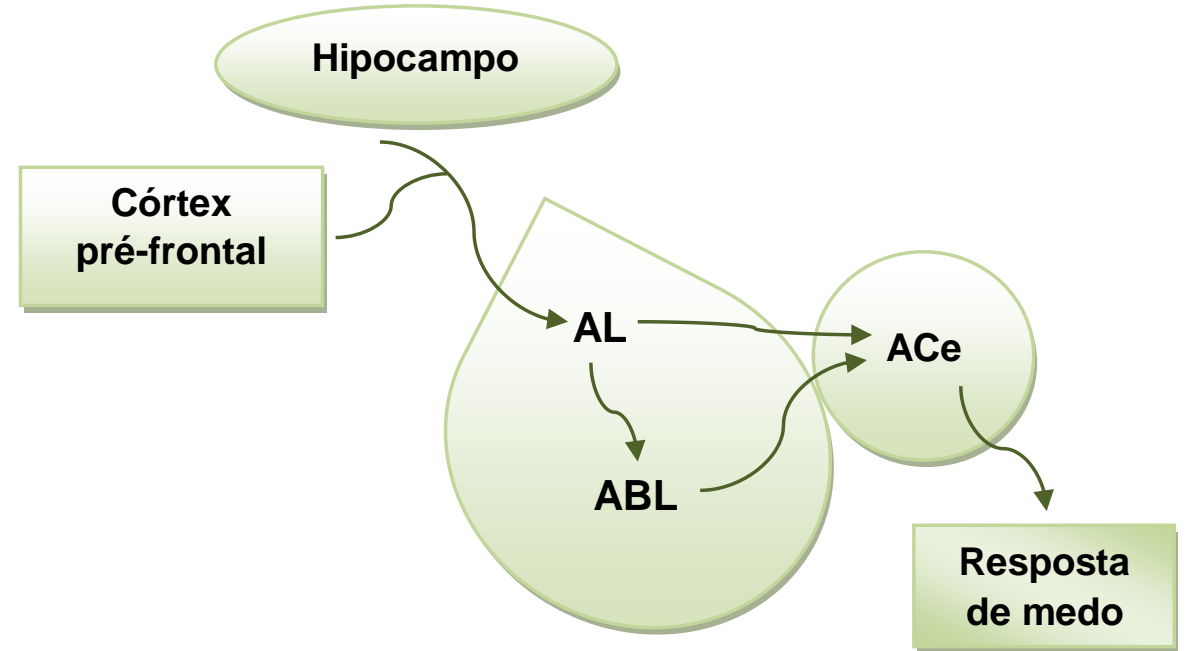

A amígdala lateral $(A L)$ recebe informações do hipocampo e do córtex pré-frontal. Essa informação é transmitida para a amígdala central (Ace) de forma direta ou indireta pela amígdala basolateral ( $\mathrm{ABL}$ ). Da amígdala central (Ace) saem às projeções para a resposta de medo. 


\subsection{Tratamento}

Ainda não existe tratamento preventivo ou curativo para a doença de Alzheimer. $O$ objetivo do tratamento medicamentoso é a estabilização do comprometimento cognitivo, do comportamento e capacitação para a realização das atividades da vida diária, com um mínimo de efeitos adversos.

O tratamento mais utilizado atualmente é com os inibidores da colinesterase e com antagonistas de baixa afinidade do receptor de glutamato do tipo NMDA (do inglês N-methyl-D-aspartate) (Hogan et al., 2008).

Os fármacos inibidores da colinesterase com indicação para a DA são a donepezila, a galantamina e a rivastigmina. Eles facilitam a neurotransmissão colinérgica pela diminuição da degradação da acetilcolina liberada por neurônios colinérgicos funcionalmente intactos.

As alterações patológicas na DA envolvem a destruição das vias neuronais colinérgicas que estão envolvidas no processo de atenção, aprendizado e memória e em outros processos cognitivos (Minger et al., 2000; Terry, Buccafusco, 2003). Diversos fármacos com ação colinérgica, como agonistas muscarínicos e nicotínicos e compostos para aumentar a liberação da acetilcolina, foram testados como tratamento para a DA, mas não houve efeito clínico relevante e ainda ocorreu uma grande incidência de efeitos adversos devido à ação colinérgica periférica (Brasil, 2010).

A donepezila, a rivastigmina e a galantamina têm propriedades farmacológicas levemente diferentes. A rivastigmina além da acetilcolinesterase inibe também outra colinesterase, a butirilcolinesterase. A galantamina, além de inibir a acetilcolinesterase, tem atividade agonista nicotínico. Cada fármaco deve ser usado de acordo com o prognóstisco e evolução do paciente, não havendo diferenças clínicas relevantes entre eles (Bond et al., 2012; Hansen et al., 2008; Lockhart et al., 2009; Wattmo et al., 2012). Esses fármacos estão recomendados para o tratamento da DA em estágio leve a moderado (Associação Médica Brasileira et al., 2011).

Já a memantina, antagonista de baixa afinidade do receptor de glutamato do tipo NMDA, age na restauração da homeostase do sistema glutamatérgico, auxiliando no controle da excitotoxicidade glutamatérgica (Parsons et al., 2007). Está 
recomendada para o tratamento da DA no estágio moderado a grave (Associação Médica Brasileira et al., 2011).

O glutamato é o principal neurotransmissor excitatório no Sistema Nervoso Central. Ele está envolvido em funções cerebrais relacionadas à aprendizagem e memória, além de participar como mediador da comunicação intercelular, plasticidade, crescimento e diferenciação celular (Izquierdo, 1994; Meldrum, 2000; Morris et al., 1986). Os receptores NMDA respondem mais lentamente ao glutamato e são considerados responsáveis pelos processos de aprendizado e memória (Malenka, Bear, 2004; Rebola et al., 2010).

Existem cada vez mais indicações de que as perturbações na neurotransmissão glutamatérgica, especialmente nos receptores NMDA, contribuem para a expressão dos sintomas e para a evolução da DA (Chalmers et al., 1990; Chen et al., 2011; Lee et al., 1995; Shankar et al., 2007). A excitotoxicidade é um dos principais eventos dessa perturbação, nela as células nervosas começam a responder de forma inapropriada a concentrações elevadas de glutamato na fenda sináptica, o que culmina com a morte celular, principalmente devido a um influxo excessivo de cálcio (Lynch, Guttmann, 2002).

Os fármacos citados acima são considerados de primeira escolha (Associação Médica Brasileira et al., 2011). Outras inúmeras substâncias têm sido propostas para preservar ou restabelecer a cognição, o comportamento e as habilidades funcionais do paciente com demência. Porém, os efeitos dessas substâncias limitam-se ao retardo na evolução natural da doença, permitindo apenas uma melhora temporária do estado funcional do paciente (Geldmacher, 2007; Hogan et al., 2008; Lovestone et al., 1997). Devido a esses fatos, o tratamento da DA deve ser multidisciplinar, envolvendo os diversos sinais e sintomas da doença e suas peculiaridades de condutas.

Alternativas de tratamento não-farmacológicos vêm ganhando espaço para amenizar os sintomas da progressão da doença, na tentativa de melhorar a qualidade de vida do paciente, principalmente no que diz respeito aos aspectos cognitivos através da estimulação física com exercícios e intelectual com leituras, jogos, passatempos etc (Baker et al., 2010; Duara et al., 2009; Faria et al., 2009; Farlow et al., 2008; Guerreiro et al., 2004; Hogan et al., 2008). 


\subsection{Enriquecimento ambiental}

Há algum tempo vem sendo descrito na literatura que pessoas que praticam atividade intelectual desde a juventude são menos propensas a desenvolver demências durante o processo de envelhecimento (Glatt et al., 1996; Kramer et al., 2004; Riley et al., 2005; Snowdon et al., 1996).

Essa estimulação cognitiva durante a vida permite a formação de uma reserva cognitiva importante no processo de neuroproteção (Scarmeas, Stern, 2003; Stern, 2006; Whalley et al., 2004). O conceito de reserva cognitiva sugere que a inteligência ou aspectos da experiência de vida como nível educacional ou profissional pode fornecer uma reserva, na forma de um conjunto de habilidades que permite a algumas pessoas lidar com a progressão de algumas doenças, como a DA melhor do que outros (Scarmeas, Stern, 2003). Há evidências de estudos de imagem funcional que indivíduos com maior escolaridade podem clinicamente ser mais resilientes aos sintomas da DA (Scarmeas et al., 2003). Envelhecer praticando atividades intelectuais e físicas, portanto, pode resultar em redes cognitivas funcionalmente mais eficientes e fornecer uma reserva cognitiva que atrasa o aparecimento de manifestações clínicas da demência (Scarmeas, Stern, 2003; Stern et al., 2005; Whalley et al., 2004).

A estimulação cognitiva vem sendo aplicada em animais utilizando-se, por exemplo, ambientes enriquecidos ( $A E)$ e foi constatado que esse estímulo causa um aumento da função cognitiva, bem como mudanças na expressão gênica relacionada à plasticidade e transmissão sináptica, além de modificações morfológicas significativas no sistema nervoso central (Loukavenko et al., 2007; Rampon et al., 2000).

Em humanos, o desenvolvimento da reserva cognitiva é influenciado por vários fatores associados como nível educacional, profissional, estilo de vida e contínua estimulação intelectual. Em animais expostos ao enriquecimento ambiental, estes fatores são fornecidos pela complexidade do ambiente e presença de novidade (Petrosini et al., 2009). Em humanos, outro fator considerado essencial para a formação da reserva cognitiva é o exercício físico (Pang, Hannan, 2013; van Praag et al., 1999). No enriquecimento ambiental, o treinamento físico dos animais é representado pela atividade exploratória vinculada à inspeção dos novos objetos e atividade motora nas rodas de atividade. 
Trabalhos recentes mostram que os animais estimulados passam a apresentar melhor desempenho e habilidade, comparativamente àqueles que viviam em um ambiente pobre de estímulos. Além disso, apresentam amplificação da transmissão sináptica e conseqüente aumento da função cognitiva, o que consiste em um fator protetor para a memória (Ferrari et al., 2001; Loukavenko et al., 2007; Nunes et al., 2003; Oliver, 2007; Schloesser et al., 2010; Segovia et al., 2009). Esse fato vem sendo observado, inclusive, quando o estímulo é aplicado durante o processo de envelhecimento ou mesmo quando é aplicado em animais velhos (Baraldi et al., submetido).

Quando há interação do organismo com o meio externo ocorrem modificações morfológicas e moleculares dos neurônios (Arteni, Netto, 2004; Ferrari et al., 2001). Uma dessas modificações é o aumento da produção de neurotrofinas, como o BDNF (brain-derived neurotrophic fator), no hipocampo, área cerebral implicada na consolidação da memória (Kobilo et al., 2011; Lent, 2008). As modificações de determinadas sinapses em áreas como córtex, hipocampo, amígdala e suas principais conexões após diferentes estimulações cognitivas, como treino de atenção e estímulo em ambiente enriquecido, são significativas para a formação e armazenamento das memórias (Izquierdo, 2002; Viel et al., 2012).

Diante da possibilidade da formação de reserva cognitiva e dos inúmeros benefícios fornecidos pelo enriquecimento ambiental, nesse trabalho avaliamos os efeitos da estimulação cognitiva em ambiente enriquecido para a memória e para os marcadores neuropatológicos de um modelo animal transgênico que superexpressa a PPA humana.

\subsection{Modelo experimental para a DA}

Os modelos animais foram criados para mimetizar características de doenças humanas, mas não existe um modelo animal perfeito, pois mesmo sendo feitas várias modificações genéticas, não temos a certeza de que este modelo está representando o que realmente acontece no humano.

Os modelos transgênicos para a DA apresentam características da doença, como déficit cognitivo, disfunção e perda sináptica, placas amilóides e aglomerados neurofibrilares, além de atrofia e morte neuronal (Balducci, Forloni, 2011). 
Os animais transgênicos, que manifestam principalmente a formação de placas senis, são gerados da mutação de três isoformas do gene da PPA humana (695, 751 e 770). A mutação no gene da PPA é nomeada de acordo com o lugar da descoberta, por exemplo, o sueco (K670N e M671L), o inglês (Londres) (V717l) o ártico (E693G), sendo que o número corresponde à isoforma da PPA (Balducci, Forloni; 2011). Em todas as mutações, as placas de $\beta$-amilóides são compostas pelos fragmentos 1-40 e 1-42 e ocupam áreas corticais e hipocampais (Howlett et al., 2004; McGowan et al., 1999).

Atualmente, os modelos utilizados não apresentam apenas uma mutação, mas várias, numa tentativa de se aproximar do que aconteceria no paciente com DA. O modelo duplo transgênico apresenta a mutação Sueca da PPA e do gene da presenilina 1 (PS1). A deposição de placas amilóides inicia-se aos nove meses de idade (Borchelt et al., 1997). Esse modelo apresenta déficit cognitivo, observado em Labirinto de Morris e teste de reconhecimento de objetos (Dinamarca et al., 2008; Howlett et al., 2004; Trinchese et al., 2008).

O mais completo modelo transgênico para a DA, hoje, é o triplo transgênico (3xTg) que apresenta, além da mutação do gene da PPA e PS1, o gene da proteína tau modificado e inserido neste animal (Oddo et al., 2003). Assim o 3xTg apresenta grande deposição de $\beta$-amilóide intracelular, precedendo a formação extracelular de placas, sendo evidente aos doze meses de idade, mas a característica mais importante deste transgênico é a formação dos aglomerados neurofibrilares. Recentemente, um novo triplo transgênico foi desenvolvido que apresenta a mutação da PPA, PS2 e mutação no gene da proteína tau (Grueninger et al., 2010; Rhein et al., 2009).

No presente trabalho o modelo transgênico utilizado foi o Tg(PDGFBAPPSwInd)20Lms, também chamado de J20. Esse modelo expressa as mutações, sueca e indiana, apresentando a isoforma 770 da PPA. Entre cinco e sete meses de idade eles apresentam placas amiloides no hipocampo, em região como o giro denteado e, aos dez meses, essa deposição está presente em grande parte dos animais TG (Hsia et al., 1999). No Labirinto de Morris, esta linhagem apresenta, também, déficit cognitivo (Chen, Bear, 2007; Palop et al., 2003).

Essa evolução lenta das características da DA no modelo, com um aparecimento das placas senis na fase adulta traz o modelo mais perto da realidade dos pacientes da DA. 


\section{OBJETIVO}

\subsection{Objetivo geral}

Diante do exposto, o objetivo desse trabalho foi avaliar a memória e as características neuropatológicas da doença de Alzheimer, em um modelo experimental, após estimulação em ambiente enriquecido.

\subsection{Objetivos específicos}

$\checkmark$ Avaliar a atividade locomotora, a memória espacial e a memória relacionada ao estímulo aversivo de animais transgênicos, Tg(PDGFB - APPSwlnd), comparativamente a seus controles selvagens (C57BI/6), antes e após a estimulação cognitiva em ambiente enriquecido, em duas idades diferentes: antes do aparecimento das placas senis (entre 3 e 7 meses de idade) e após o aparecimento das mesmas (entre 8 e 12 meses de idade).

$\checkmark$ Determinar a densidade de terminais pré-sinápticos e a densidade de corpos neuronais em áreas cerebrais relacionadas à memória dos animais de 7 e 12 meses estimulados em ambiente enriquecido, comparativamente àqueles não estimulados.

$\checkmark$ Avaliar e quantificar a presença de placas senis e emaranhados neurofibrilares em amostras semelhantes. 


\section{MATERIAL E MÉTODOS}

\section{1 $\underline{\text { Animais }}$}

As matrizes dos animais transgênicos que superexpressam a PPA humana, Tg (PDGFB - APPSwInd), foram fornecidas pela companhia The Jackson Laboratory (Gladstone Institute, EUA) e foi estabelecida uma colônia no biotério do Departamento de Ciências Fisiológicas da Faculdade de Ciências Médicas da Santa Casa de São Paulo (FCMSCSP), sob responsabilidade do Prof. Dr. Hudson Buck (Protocolo ClBio no 2008/2). Esses animais, denominados TG, apresentam perda funcional e estrutural nos neurônios (a partir de 2 a 4 meses de idade), mesmo antes da formação das placas. Ao redor de 8 a 10 meses de idade, cerca de $45 \%$ dos animais apresentam placas amilóides (Hsia et al., 1999).

Um primeiro grupo de animais TG machos foi mantido em ambiente enriquecido (AE) dos 3 aos 7 meses de idade $(n=9)$ ao mesmo tempo em que um grupo controle foi mantido em caixas-padrão $(n=8)$. Um segundo grupo de animais TG foi mantido em AE $(n=6)$ dos 8 aos 12 meses de idade ao mesmo tempo em que um grupo controle, de mesma idade, foi mantido em caixas-padrão $(n=6)$.

Os controles genéticos dos animais TG pertencem à linhagem C57BI/6, denominados "wild type" (WT) no presente trabalho. Um grupo de WT foi mantido em $A E$ dos 3 aos 7 meses de idade ( $n=7)$, ao mesmo tempo em que um grupo controle foi mantido em caixas-padrão $(n=10)$. Outro grupo, composto apenas por animais controles em caixas-padrão $(n=4)$, foi observado dos 8 aos 12 meses de idade.Todos os procedimentos experimentais foram realizados de acordo com os "princípios éticos para uso de animais de laboratório" descritos pela Sociedade Brasileira em Ciência de Animais de Laboratório (SBCAL, antigo Colégio Brasileiro de Experimentação Animal, COBEA) e de acordo com a Lei Arouca, aprovada em 2008. Esse projeto foi aprovado pelo Comitê de Ética em Uso de Animais (CEUA) do Instituto de Ciências Biomédicas da Universidade de São Paulo (ICB-USP). 


\subsection{Ambiente enriquecido}

Os animais transgênicos mais novos (3 meses) e os mais velhos (8 meses), assim como os WT de 3 meses, foram colocados em caixas contendo vários objetos incluindo escadas, rodas de exercício, bolas, objetos de plástico e madeira (Figura 4) (Rampon et al., 2000). Os objetos foram trocados a cada 2 ou 3 dias. Os animais foram mantidos nesse ambiente por quatro meses. Outro grupo de animais semelhantes e de mesma idade foi mantido em caixas regulares. Todos os animais receberam água e comida "ad libitum".

Figura 4 - Ambiente Enriquecido

A

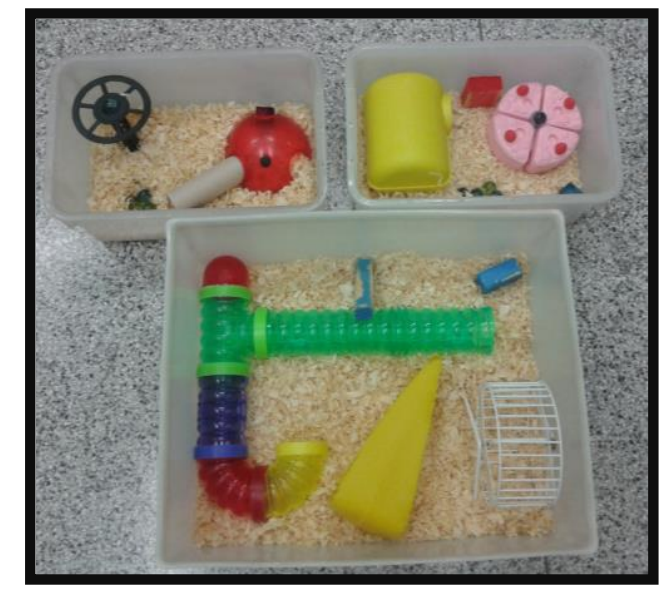

B

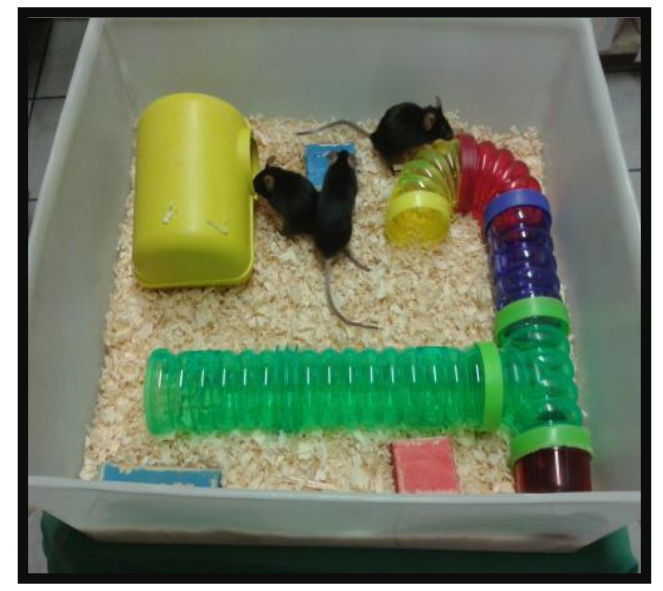

A: Exemplos de ambiente enriquecido. B: Animais na caixa após troca dos acessórios.

\subsection{Avaliacão comportamental}

Os testes comportamentais para avaliação da memória utilizados foram, o Labirinto de Barnes para a avaliação da memória espacial e a esquiva inibitória para avaliação da memória relacionada ao estímulo aversivo. Juntamente com estes testes foi também verificada a locomoção dos animais em caixa de atividade motora.

Na primeira fase, o grupo de animais adultos jovens, (3 a 7 meses de idade), foi avaliado com testes de memória realizados aos 5 meses com repetição aos 7 meses de idade. Na segunda fase outro grupo de animais adultos, de 8 a 12 meses 
de idade, foi avaliado com testes de memória apenas aos 12 meses de idade e repetição 7 dias após a primeira bateria de testes.

A diferença de protocolo entre os grupos foi estabelecida para que fosse possível avaliar a capacidade de aprendizado e memória do grupo de animais aos 12 meses de idade. Dessa forma, pretendíamos evitar que a repetição dos testes levasse a um reforço desse aprendizado nessa idade. Outro fato considerado é que nessa idade esse modelo experimental apresenta placas senis no hipocampo, como relatado anteriormente (Hsia et al., 1999), diferente do observado em animais mais jovens. O quadro abaixo (Figura 5) mostra o desenho experimental utilizado nesse trabalho.

Figura 5 - Desenho experimental

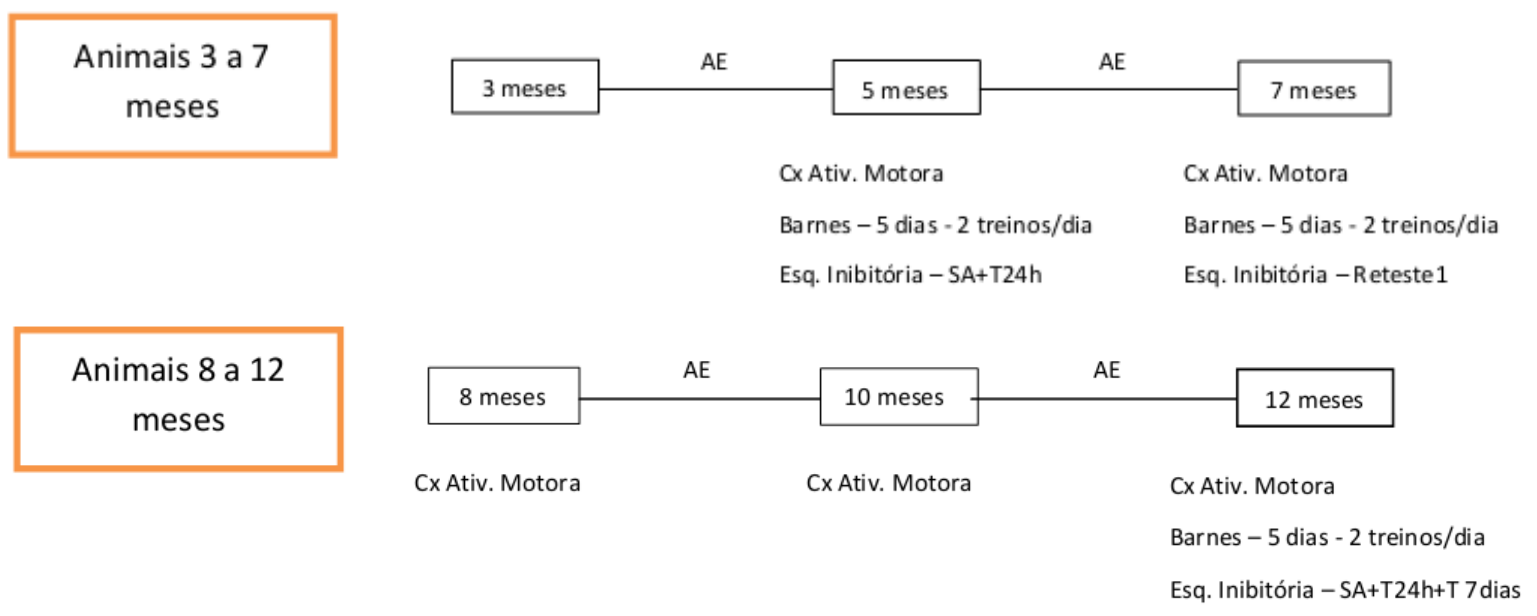

\subsubsection{Avaliação da atividade motora}

Todos os métodos utilizados para avaliação da memória em roedores dependem de boa deambulação dos animais (Holmes et al., 2002; Miyakawa et al., 2001; Reiserer et al., 2007; Wolfer et al., 1998). Dessa forma, a atividade motora dos animais foi avaliada a fim de eliminar qualquer possibilidade de que, se houvesse mau desempenho nas provas, este fosse devido a déficit motor. O equipamento utilizado é constituído por uma caixa acrílica com sensores infra-vermelhos nas laterais que medem a deambulação e exploração vertical dos animais. Os camundongos foram colocados individualmente no equipamento por cinco minutos, com registro de atividade a cada um minuto. 


\subsubsection{Avaliação da memória espacial}

A avaliação da memória espacial foi realizada utilizando-se o labirinto de Barnes, composto por uma prancha circular branca com 31 buracos distribuídos radialmente, circundada por uma parede escura onde quatro símbolos (cruz, quadrado, círculo e triângulo) amarelos foram dispostos em sequência. Uma caixinha preta com maravalha (caixa de escape) foi colocada em baixo de um dos buracos (sempre o mesmo para cada animal).

O animal foi colocado no centro da prancha, onde permaneceu por $1 \mathrm{~min}$ em uma caixa de acrílico para reconhecer o ambiente a sua volta. Sobre a prancha foi colocada uma luz (70 W) considerada como estímulo incômodo para o camundongo. Em seguida, ele foi solto e teve, no máximo, cinco minutos para encontrar a caixa de escape, onde ele foi deixado por mais um minuto, com as luzes da sala apagadas e a caixa fechada. A latência para encontrar a caixa de escape foi registrada.

Com o grupo de animais mais velhos, aos 12 meses de idade foi registrado, ainda, o número de erros, ou seja, a quantidade de vezes que o animal colocava a cabeça no buraco errado, até achar a caixa de escape, também como parâmetro de avaliação da memória. O teste é baseado na preferência inata de camundongos por lugares escuros e fechados. Os animais passaram por duas provas por dia, com intervalo de três horas entre cada uma, durante cinco dias consecutivos.

\subsubsection{Avaliação da memória relacionada a estímulo aversivo}

Para avaliar esse tipo de memória foi utilizado o equipamento de esquiva inibitória. Tal equipamento possui dois compartimentos, um escuro e outro claro (este com uma lâmpada fixada na porção superior), separados por uma portaguilhotina. $\mathrm{O}$ chão é formado por barras metálicas, que permitem a passagem de corrente elétrica com intensidade controlável.

Na sessão de aquisição, cada animal foi colocado no lado claro da caixa e teve o tempo máximo de 300 segundos para explorar o local. Ao passar para o lado escuro, a porta se fechava automaticamente e ele recebia um leve choque nas patas $(0,5 \mathrm{~mA})$ por dois segundos. A latência para o camundongo atravessar de um lado para o outro da caixa foi registrada. Após $24 \mathrm{~h}$, um teste para avaliar a retenção da memória de longa duração foi realizado, onde se verificou, novamente, a latência 
para entrada no lado escuro da caixa. Caso o animal passasse para aquele lado novamente, recebia um leve choque nas patas $(0,5 \mathrm{~mA})$. Quanto maior a latência, maior a lembrança do animal com relação àquele contexto (Izquierdo et al., 1992).

\subsection{Análise histológica}

Ao final dos protocolos comportamentais, os animais foram anestesiados com halotano e decapitados para a extração dos cérebros. As amostras foram imediatamente congeladas em dimetilbutano resfriado em gelo-seco $\left(-45 \mathrm{a}-55^{\circ} \mathrm{C}\right)$ e armazenadas a $-80^{\circ} \mathrm{C}$ até a data de preparo dos cortes histológicos. A preservação das amostras por congelamento e não por fixação química permite a utilização em diversos tipos de análises (radioautografia, western-blot, imunohistoquímica).

Os cortes histológicos congelados $(20 \mu \mathrm{m})$ de um dos hemisférios cerebrais foram obtidos utilizando-se um criostato (Micron-Zeiss, Alemanha) e coletados diretamente em lâminas de vidro, previamente gelatinadas, para evitar-se o desprendimento dos cortes. Os conjuntos de cortes histológicos foram mantidos a $80^{\circ} \mathrm{C}$ até o momento de utilização.

\subsubsection{Análise das densidades de terminais pré-sinápticos}

O número de sinapses foi avaliado utilizando-se imunohistoquímica para detecção da glicoproteína sinaptofisina (Syn - Abcam, USA, ab68851-100) que se localiza na membrana da vesícula pré-sináptica no cérebro e medula espinhal e é considerada um marcador pré-sináptico.

Para isso, os cortes foram aquecidos à temperatura ambiente e mantidos dessa forma até que a condensação que se forma nessa temperatura, desaparecesse (5 min). Após secarem, os cortes foram fixados por imersão em acetona gelada $\left(-20^{\circ} \mathrm{C}\right)$ por 5 min em temperatura ambiente. Após a fixação, os cortes foram rapidamente lavados em tampão fosfato-salina (PBS) por 3 vezes. 0 excesso de tampão foi retirado e os cortes foram incubados por $20 \mathrm{~min}$ com soro de cabra (Normal Serum) para bloquear ligações inespecíficas. O excesso de soro bloqueador foi retirado e os cortes foram incubados por 6h com o anticorpo primário anti-Syn (1:2000). 
Ao término do período de incubação, os cortes foram imersos por $5 \mathrm{~min}$ em PBS e incubados por 30 min com a solução contendo o anticorpo secundário biotinilado. Após a incubação, os cortes foram processados pelo método do Complexo Avidina Biotina-Peroxidase (Vectastain elite ABC Kit - Vector laboratories, USA), de acordo com instruções do fabricante. Para revelação das imunomarcações utilizou-se o DAB (3,3'-Diaminobenzidine - Sigma-Aldrich, D800-1) por $4 \min$ e 30 segundos. Em seguida procedeu-se com as lavagens em água destilada, álcool $75 \%, 95 \%$ e $100 \%$ e duas passagens em xilol por 5 min cada etapa.

Os cortes histológicos foram quantificados por densidade óptica relativa (ROD) utilizando-se o sistema MCID de análise densitométrica digital (InterFocus Imaging Ltd., Linton, England). Para cada núcleo analisado, em cada animal, foram obtidas, pelo menos, quatro leituras. A análise foi feita de acordo com a divisão dorso-ventral do hipocampo.

\subsubsection{Quantificação de placas $\beta$-amilóide e análise das densidades de corpos neuronais}

O cresil-violeta é um corante básico utilizado para evidenciar o citoplasma de neurônios. No citoplasma encontramos algumas estruturas conhecidas como corpúsculos de Nissl. Esses corpúsculos são compostos, basicamente, por RNA, o que faz com que tenham grande afinidade por corantes básicos. Assim, a coloração cresil-violeta serve como indicador da viabilidade neuronal, pois, quando da ocorrência de lesão ou morte neuronal, esses corpúsculos podem desaparecer (Carson, 1990; Pilati et al., 2008).

Nesta análise as amostras de tecido cerebral foram fixadas (10 min) em paraformaldeído 4,0\%, lavadas em água destilada e coloridas com vermelho Congo por $45 \mathrm{~min}$. Ao retirar as lâminas da coloração lavou-se com água destilada novamente e em seguida mergulhou-se as lâminas no álcool alcalino. As lâminas foram, então, coloridas com cresil-violeta por $10 \mathrm{~min}$. Em seguida, procederam-se as lavagens em álcool e xilol.

A aquisição das imagens e a análise histológica foram feitas usando o equipamento Nikon Eclipse E600 light microscope (Kanagawa, Japan) conectado a um sistema digital de aquisição de imagens (IP Lab, Scanalytics, MD, USA). Foram analisadas a densidade total de placas dos animais e a distribuição das mesmas, 
assim como a densidade de corpos neuronais, na região do hipocampo, de acordo com a divisão dorso-ventral.

\subsubsection{Identificação e análise de emaranhados neurofibrilares}

A presença de emaranhados neurofibrilares nas amostras estudadas foi avaliada utilizando-se imunohistoquímica e imunofluorescência para tau hiperfosforilada com anticorpo anti-tau (Neurofibrillary Tangles Marker, Clone TAU-5 - Biosource, AHB0042Z). Para tal análise foi necessário padronização e elaboração de protocolo.

Para início de padronização, procedeu-se com protocolo já descrito para imunohistoquímica no item 3.4.1. Os cortes foram incubados overnight, por $14 \mathrm{~h}$, com o anticorpo primário anti-tau, nas concentrações 1:500, 1:1000 e 1:2000. Para revelação das imunomarcações utilizou-se o DAB (3,3'-Diaminobenzidine - SigmaAldrich, D800-1).

Após esse primeiro teste foi observado que não houve diferença entre as lâminas com anticorpo anti-tau e a lâmina para controle negativo. Mediante esse fato, procedeu-se um novo teste onde se substituiu o tampão fosfato-salina (PBS), por um PBS com Tween 20 para minimizar as ligações não-específicas (Pace, 2009; Buchwalow et al., 2011) e utilizou-se- o anticorpo anti-tau na concentração 1:500, por $2 \mathrm{~h}$, conforme instruções do fabricante. Novamente não foi observada diferença para o controle negativo.

Mediante este fato, foi testado, então, outro revelador, o $\operatorname{TMB}(3,3$ ', 5, 5'Tetramethylbenzidine - TMB Substrate Kit For Peroxidase - Vector Laboratories, USA). A incubação com anticorpo anti-tau foi feita na concentração de 1:500, agora por 4 h. O TMB foi preparado e utilizado após 5 min. Observou-se então, novamente, ausência de diferença para o controle negativo.

Para finalizar a padronização da imunohistoquímica foi realizado uma contracoloração. Dois processos foram realizados para marcação de estruturas do corpo celular, no primeiro foi utilizado a coloração com hematoxilina de Gill e no segundo a coloração cresil-violeta juntamente com a coloração vermelho Congo para a marcação das placas $\beta$-amilóide. Em ambos processos foi realizado o protocolo padrão para imunohistoquímica, com PBS acrescido de Tween 20, anticorpo anti-tau na concentração de 1:500 e incubação por 4 h. Revelou-se, então, com um novo 
DAB (Liquid DAB + Substrate Chromogen System - DAKO, EUA) e em seguida procedeu-se com a coloração como descrito no item 3.4.2 para a coloração cresilvioleta com vermelho Congo. Para a coloração com hematoxilina de Gill, a amostra foi mergulhada por $30 \mathrm{~s}$ no marcador. Em seguida foi feito a lavagem em água destilada por 2 min, as lavagens em álcool e xilol e a montagem das lâminas.

Para o mesmo anticorpo, ainda com a finalidade de analisar a densidade dos emaranhados neurofibrilares, foi realizado um protocolo de imunofluorescência. Os cortes foram aquecidos à temperatura ambiente e fixados por imersão em acetona gelada $\left(-20^{\circ} \mathrm{C}\right)$ por 5 min. Após a fixação, os cortes foram lavados em PBS + Tween 20 por 2 min, 2 vezes. O excesso de tampão foi retirado e os cortes foram incubados por 30 min com Normal Serum acrescido de Tween 20 e Triton para bloquear ligações inespecíficas. O excesso de soro bloqueador foi retirado e os cortes foram incubados por $4 \mathrm{~h}$ com o anticorpo primário anti-proteína tau (1:500).

Ao término do período de incubação, os cortes foram lavados brevemente em PBS com Tween 20 e incubados por 30 min com a solução contendo o anticorpo secundário conjugado com fluoresceína iso-til-cianato (Anti-rabbit IgG Fitc Conjugate - Sigma-Aldrich, F6005 ). Após incubação, os cortes foram lavados três vezes em PBS com Tween 20, por 2 min cada. Para revelação das imunomarcações e preparação das lâminas utilizou-se o DAPI (Diamidino-2-phenylindole Fluoroshield with DAPI - Sigma-Aldrich, F6057), no escuro.

A aquisição das imagens e a análise histológica foram feitas usando o equipamento Nikon Eclipse E600 light microscope (Kanagawa, Japan) conectado a um sistema digital de aquisição de imagens (IP Lab, Scanalytics, MD, USA).

$A$ análise por imunohistoquímica e imunofluorescência da densidade dos emaranhados neurofibrilares foi feita somente para o grupo de animais de 8 a 12 meses de idade.

\subsection{Análise estatística}

Os resultados foram expressos como médias \pm erro-padrão ou medianas com intervalos interquartis e analisados utilizando-se o programa GraphPad Prism (GraphPad Software, San Diego, CA, versão 5) e Statistica (StatSoft. Inc., USA, versão 7). Somente valores para $\mathrm{P}<0,05$ foram considerados estatisticamente significativos. 
A atividade locomotora dos grupos de 3 a 7 e 8 a 12 meses de idade foi analisada utilizando-se ANOVA de medidas repetidas seguida de Bonferroni. Os fatores analisados foram linhagem, tratamento e idade.

A análise dos dados referentes à avaliação da memória espacial foi realizada utilizando-se ANOVA de uma via seguida de Dunnet, para comparação do desempenho entre o primeiro e o quinto dia de teste, em cada grupo experimental. A comparação entre grupos foi feita utilizando-se ANOVA de medidas repetidas seguida de Bonferroni. Os fatores analisados foram linhagem, tratamento e o desempenho durante os 5 dias de teste.

Para análise dos resultados adquiridos em equipamento de esquiva inibitória foi utilizada a ANOVA de uma via seguida de Dunn para dados não paramétricos (método de Kruskal-Wallis).

Os dados obtidos nas análises teciduais foram comparados por ANOVA de medidas repetidas seguida pelo teste de Bonferroni para cada região estudada. Os fatores analisados foram linhagem, tratamento e localização (dorsal e ventral). 


\section{RESULTADOS}

\subsection{Estudo comportamental e histológico dos animais de 3 a 7 meses}

\subsubsection{Avaliação da atividade motora}

$\mathrm{Na}$ avaliação da atividade locomotora, foi observado que todos os grupos apresentaram deambulação semelhante, a não ser pelo grupo TG-AE. Dessa forma, houve interação significativa entre os fatores analisados $(F(3,30)=8,30 ; P=0,01)$, uma vez que os animais TG-AE, aos sete meses de idade, apresentaram redução significativa de $44 \%$ da atividade motora em relação aos cinco meses de idade $(808,40 \pm 71,33$ unidades) (Figura 6).

Figura 6 - Avaliação da deambulação dos animais WT e TG, aos 5 e 7 meses de idade, em caixa de atividade motora

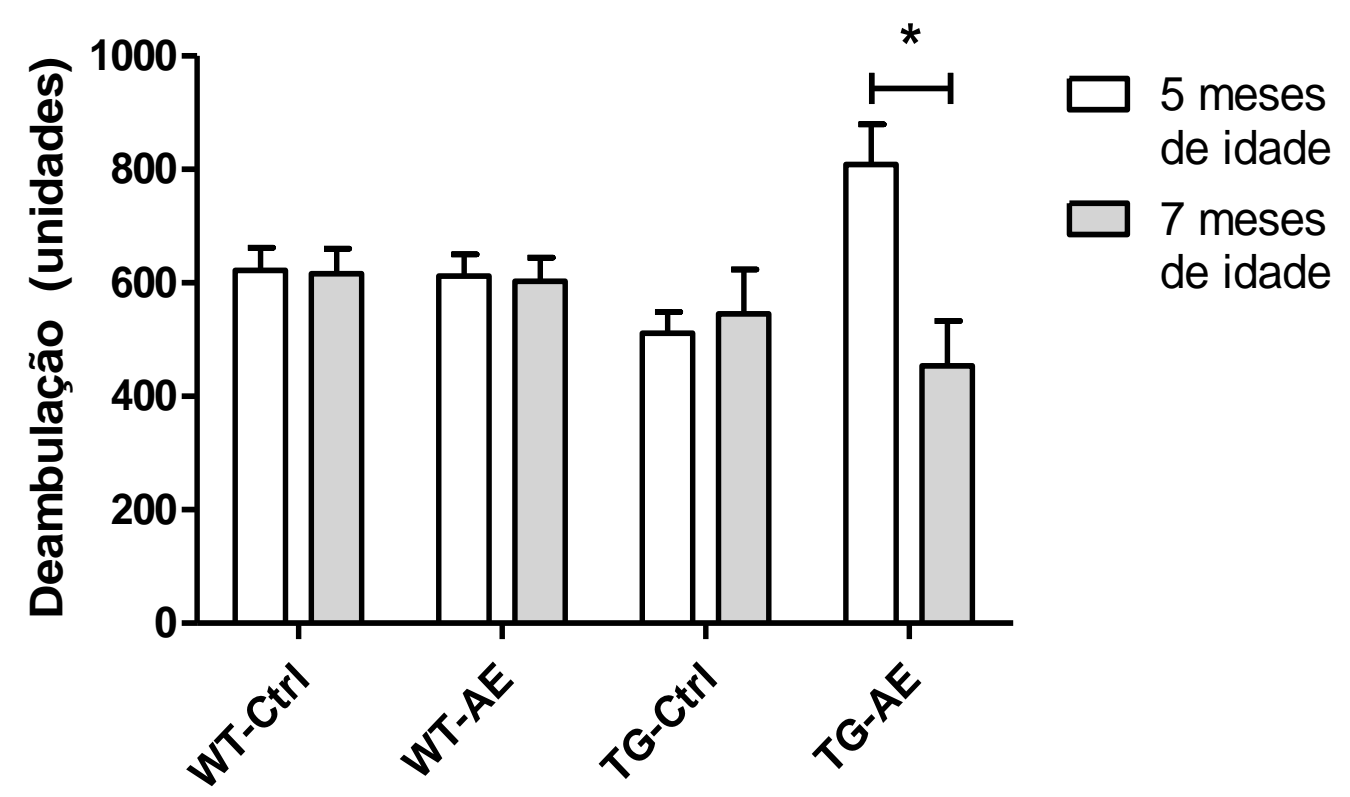

Avaliação da deambulação de camundongos C57BI/6 (WT-Ctrl e WT-AE) e transgênicos que superexpressam a PPA humana (TG-Ctrl e TG-AE) em caixa de atividade motora, aos cinco e sete meses de idade. Os histogramas e barras verticais são as médias \pm erro-padrão das médias. *: $\mathrm{P}<$ 0,05 . 
$\mathrm{Na}$ avaliação da exploração vertical, foi verificado que todos os grupos apresentaram redução do comportamento, embora na maioria dos grupos essa redução não tenha sido significativa. Houve interação significativa dos mesmos fatores analisados anteriormente $\left(F_{(3,30)}=6,28 ; P=0,02\right)$, pois foi observado que 0 grupo TG-AE, aos sete meses de idade, apresentou redução significativa de $58 \%$ na exploração vertical em relação aos cinco meses de idade $(51,22 \pm 4,19)$ (Figura 7 ).

Figura 7 - Avaliação da exploração vertical dos animais WT e TG, aos 5 e 7 meses de idade, em caixa de atividade motora

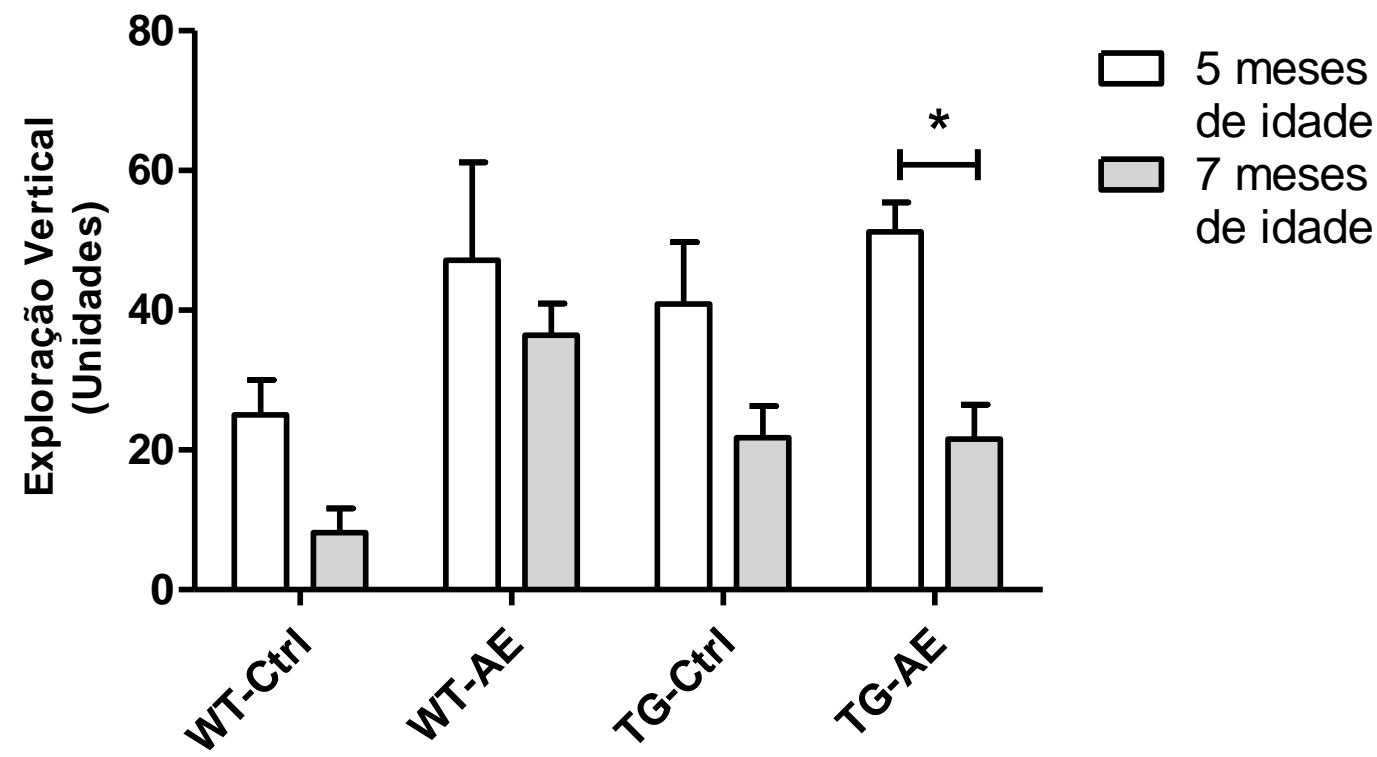

Avaliação da exploração vertical de camundongos C57BI/6 (WT-Ctrl e WT-AE) e transgênicos que superexpressam a PPA humana (TG-Ctrl e TG-AE) em caixa de atividade motora, aos cinco e sete meses de idade. Os histogramas e barras verticais são as médias \pm erro-padrão das médias. *: $\mathrm{P}<$ 0,001 . 


\subsubsection{Avaliação da memória espacial}

$\mathrm{Na}$ avaliação geral da memória espacial, aos cinco meses de idade, não foi verificada diferença do comportamento, independente da linhagem, tratamento ou tempo de observação $\left(F_{(3,120)}=1,91, P=0,11\right)$. Entretanto, dentro de cada grupo, foi verificado que os animais WT-Ctrl, WT-AE e TG-Ctrl apresentaram uma diminuição significativa da latência para achar a caixa de escape ao longo dos cinco dias de observação, respectivamente, de 82,67\%, 61,09\% e 82,82\% (Latências no primeiro dia de observação: $120,00 \pm 15,57 \mathrm{~s} ; 82,43 \pm 38,48 \mathrm{~s} ; 124,50 \pm 26,45 \mathrm{~s}$, respectivamente) (Figura 8). Com relação a esse parâmetro, o grupo TG-AE não mostrou diferença, pois já iniciou o teste com baixa latência para achar a caixa de escape. Esse tempo inicial reduzido foi significativamente diferente do grupo TG-Ctrl $(124,50 \pm 26,45 \mathrm{~s}, \mathrm{P}<0,05)$.

Figura 8 - Avaliação da latência para achar a caixa de escape dos animais WT e $\mathrm{TG}$, aos 5 meses de idade, no labirinto de Barnes

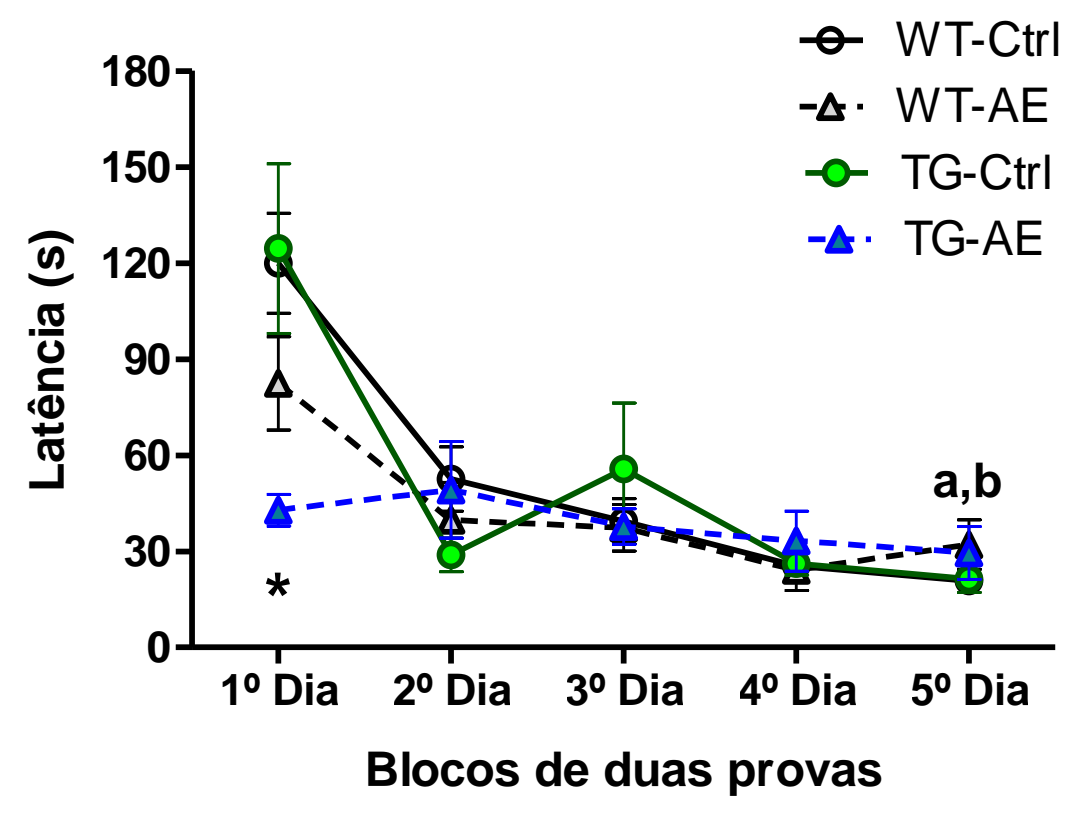

Os símbolos e barras verticais são as médias \pm erro-padrão das médias. *: $\mathrm{P}<0,05$ entre TG-Ctrl e TG-AE; a: P < 0,0001 entre dias 1 e 5 do grupo WT-Ctrl e TG-Ctrl; ; b: P $<0,05$ entre dias 1 e 5 do grupo WT-AE. 
Ao passarem pelo mesmo teste aos 7 meses de idade, todos os grupos mostraram que retiveram a memória da avaliação inicial, novamente independente da linhagem, tratamento ou tempo de observação $\left(F_{(3,120)}=1,84, P=0,13\right)$. No grupo TG-AE foi observada uma latência maior que nos outros grupos, porém os valores registrados não apresentaram diferença estatística (Figura 9).

Figura 9 - Avaliação da latência para achar a caixa de escape dos animais WT e TG, aos 7 meses de idade, no labirinto de Barnes

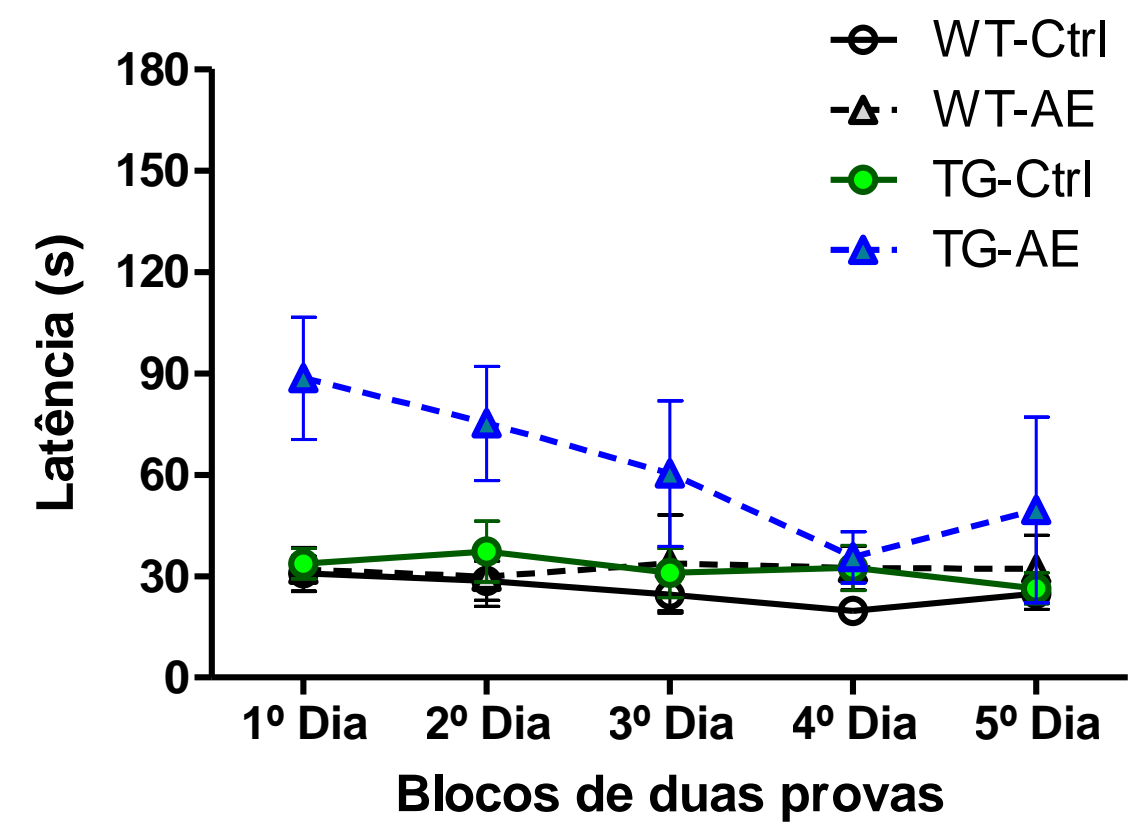

Os símbolos e barras verticais são as médias \pm erro-padrão das médias. 


\subsection{3 $\underline{\text { Avaliação da memória relacionada ao estímulo aversivo }}$}

Na sessão de aquisição (SA), aos cinco meses de idade, os animais WT e TG apresentaram latências semelhantes, independente da estimulação em ambiente enriquecido. A mediana geral das latências (com intervalos interquartis) na SA foi 20,00 s (7,97/33,25 s) (n=34).

$\mathrm{Na}$ sessão de teste, realizada $24 \mathrm{~h}$ após a SA, foi observado que todos os animais retiveram a informação adquirida, não havendo diferença entre os grupos [300,00 s (300,00/300,00 s)] (Figura 10).

Figura 10 - Avaliação da memória relacionada ao estímulo aversivo dos animais WT e TG, aos 5 meses de idade, em esquiva inibitória - Sessão de Aquisição (SA) e Teste $24 \mathrm{~h}$

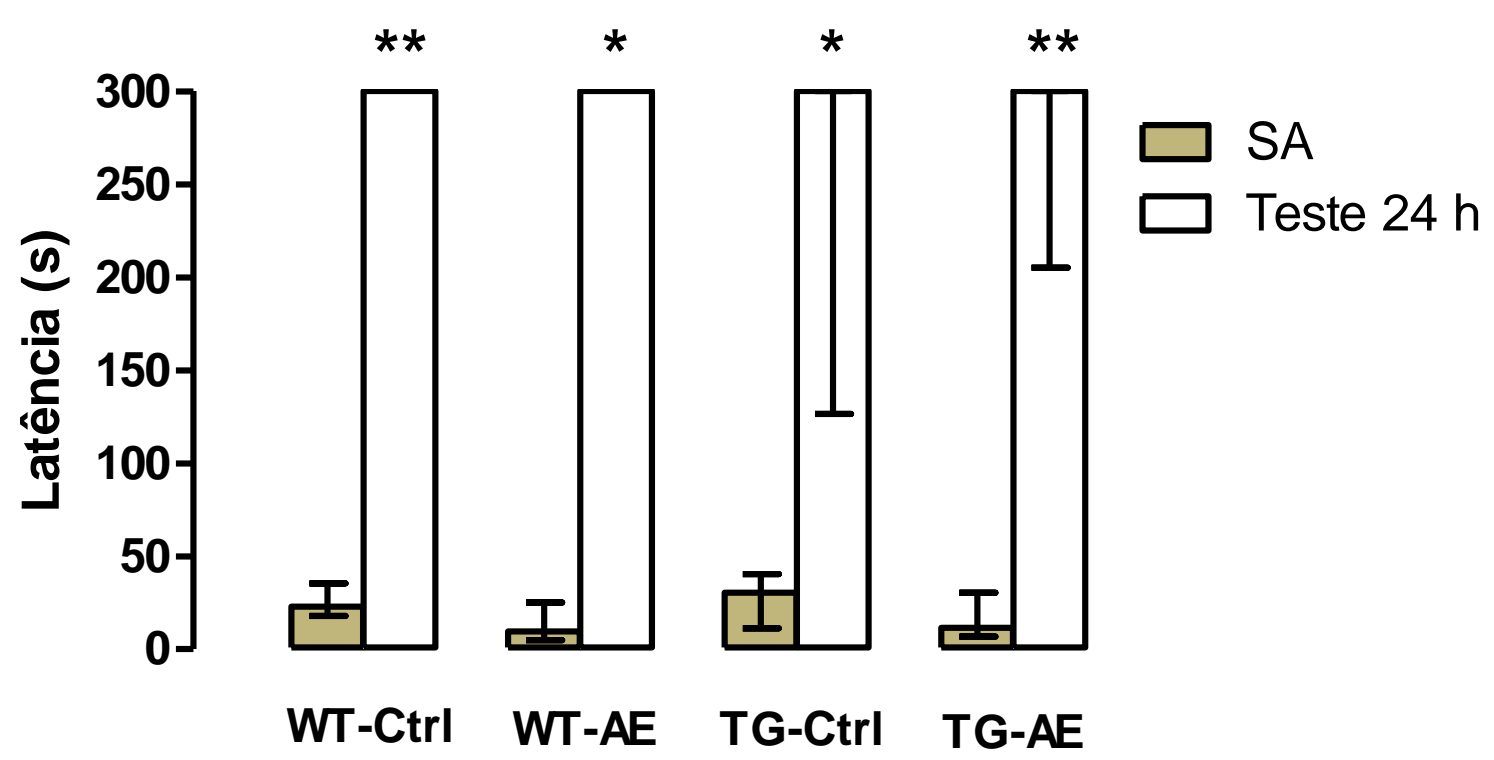

Os histogramas e barras verticais são as medianas e intervalos interquartis. ${ }^{*}: \mathrm{P}<0,05 ;{ }^{* *}: \mathrm{P}<0,01$. 
Aos sete meses de idade foi observado que os animais WT não estimulados em ambiente enriquecido apresentaram redução significativa da latência $[44,20 \mathrm{~s}$ $(32,63 / 56,20 \mathrm{~s})]$, o que significa que não se lembraram da informação adquirida aos cinco meses de idade (Figura 11). Por outro lado, o grupo WT estimulado não apresentou diferença aos sete meses, o que indica, apesar da grande dispersão dos dados, que os animais mantiveram a memória relacionada ao estímulo [74,90 s (62,80/256,90 s)] (Figura 11).

Com relação aos animais TG-Ctrl, foi observado que aos sete meses houve uma diminuição significativa na latência de passagem para o compartimento escuro do equipamento $[29,60 \mathrm{~s}(15,63 / 51,38 \mathrm{~s})]$, mostrando que os animais não se lembraram da tarefa adquirida anteriormente (Figura 11). Este resultado, no entanto, não se repetiu no grupo TG-AE $[199,20$ s (30,15/300 s)], pois não há diferença significativa entre o teste realizado aos 5 meses e aos 7 meses, indicando que, apesar da dispersão dos dados, o grupo de animais TG estimulados lembraram da tarefa (Figura 11).

Figura 11 - Avaliação da memória relacionada ao estímulo aversivo dos animais WT e TG, aos 7 meses de idade, em esquiva inibitória - Teste $24 \mathrm{~h}$ e Reteste1

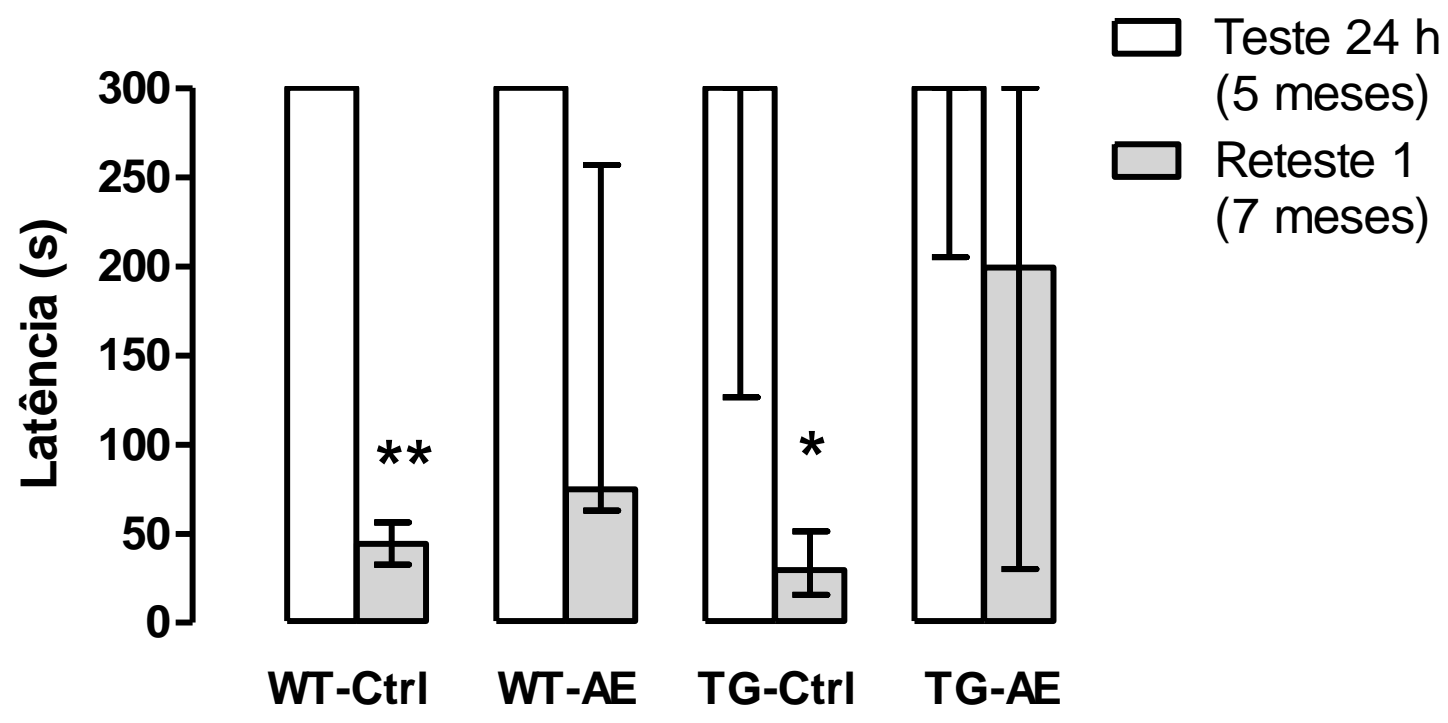

Os histogramas e barras verticais são as medianas e intervalos interquartis. ${ }^{*}$ : $\mathrm{P}<0,05 ;{ }^{*}$ : $\mathrm{P}<$ 0,0001 . 


\subsubsection{Quantificação das imunomarcações para Sinaptofisina}

$\mathrm{Na}$ avaliação da densidade de terminais pré-sinápticos por imunohistoquímica, foi verificado que todos os grupos, aos sete meses de idade, apresentaram densidade semelhante desse marcador nas regiões hipocampais observadas (Figura 12).

Figura 12 - Quantificação de terminais pré-sinápticos em regiões do hipocampo de animais WT e TG, aos 7 meses de idade, utilizando anticorpo anti-sinaptofisina

PyCA1

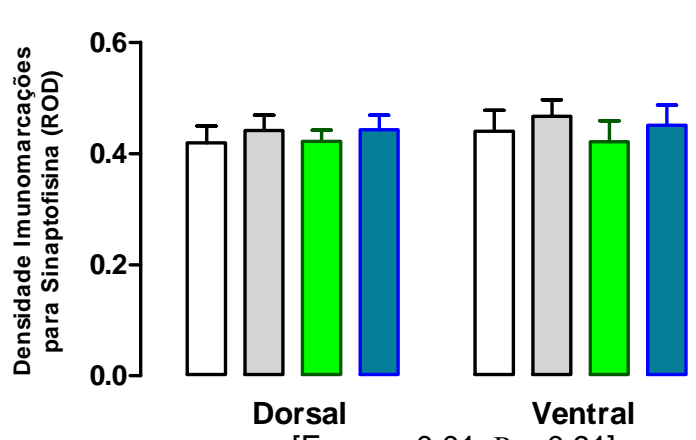

$\left[F_{(3,12)}=0,01, P=0,91\right]$

GrDG

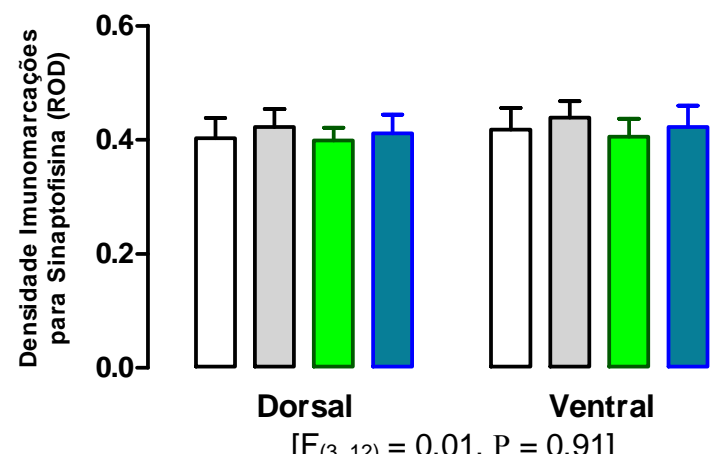

CA1

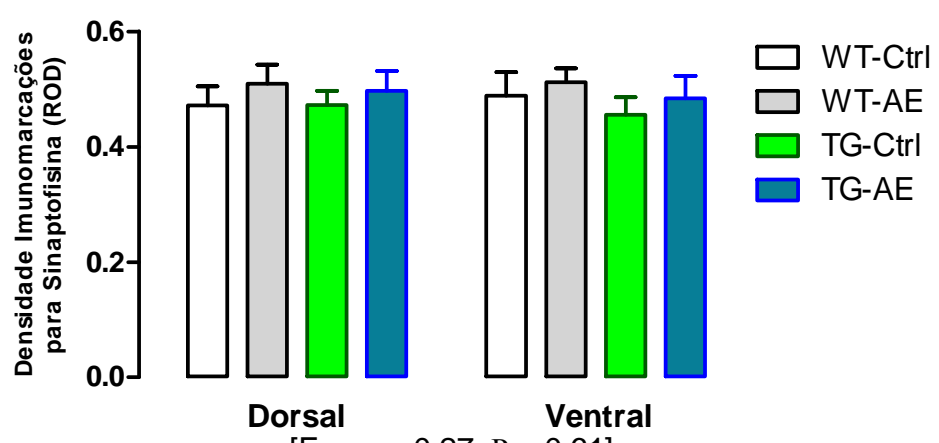

$\left[\mathrm{F}_{(3,12)}=0,27, \mathrm{P}=0,61\right]$

MoDG

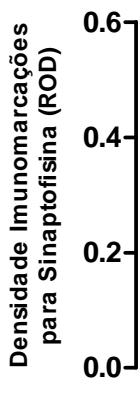

0.0

$F_{(3,12)}=0,01, P=0,91$

PoDG

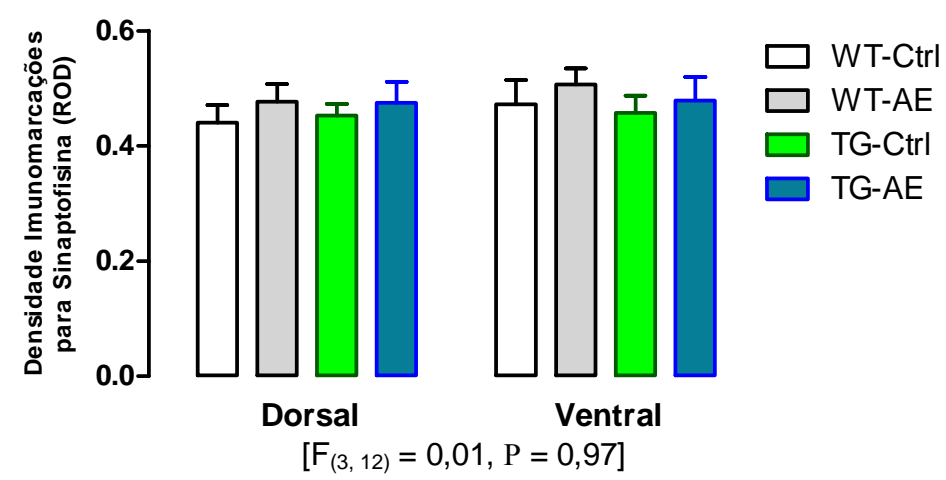

As barras verticais são as médias \pm erro-padrão das médias. 
$\mathrm{Na}$ região do córtex (Figura 13A), importante para o armazenamento da memória, e na amígdala (Figura 13B), região envolvida com a resposta ao estímulo aversivo, foi verificado que todos os grupos, aos sete meses de idade, também apresentaram densidade semelhante desse marcador.

Figura 13 - Quantificação de terminais pré-sinápticos no Córtex (A) e Amígdala (B) de animais WT e TG, aos 7 meses de idade, utilizando anticorpo anti-sinaptofisina
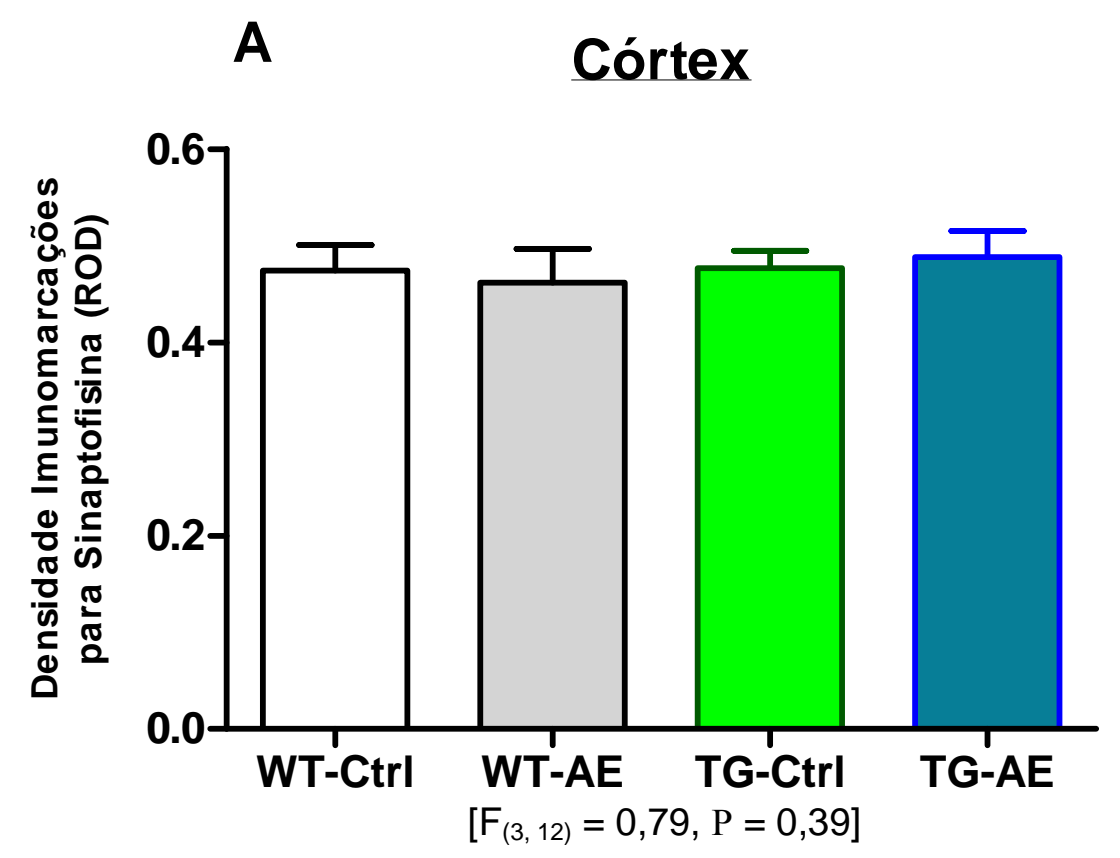

B Amígdala

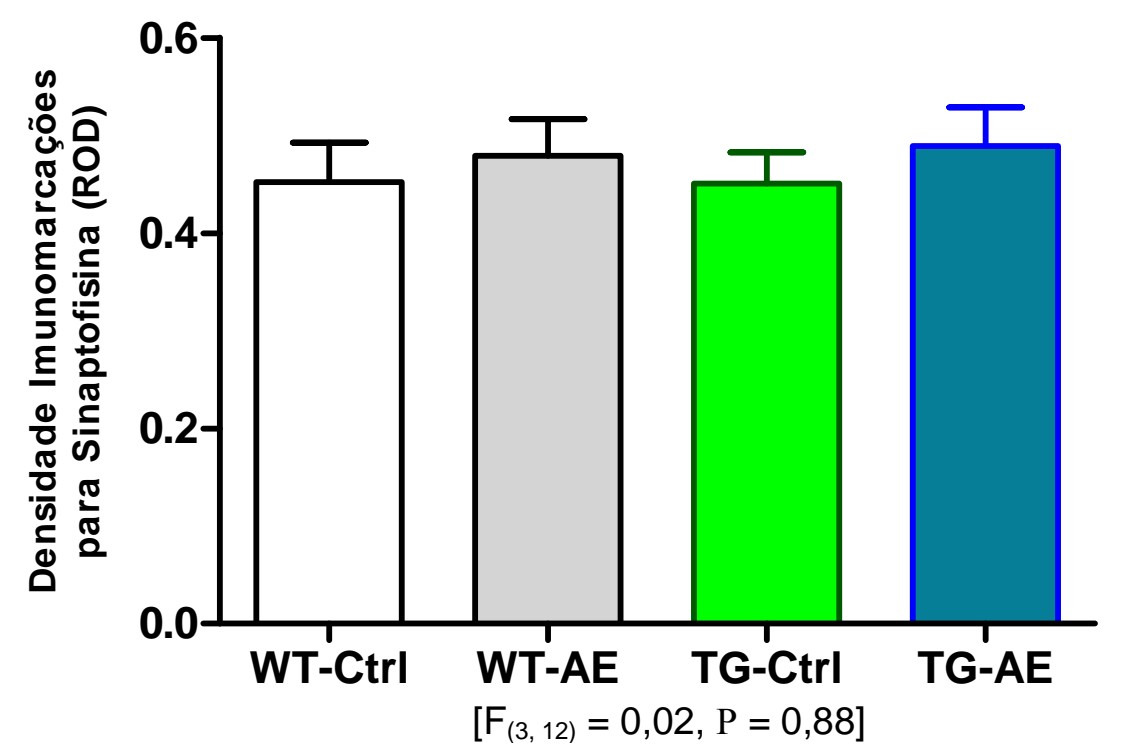

Os histogramas e barras verticais são as médias \pm erro-padrão das médias. 


\subsubsection{Análise da densidade de corpos neuronais}

$\mathrm{Na}$ avaliação da densidade de corpos neuronais no hipocampo foi verificado que na região de células piramidais do CA1(PyCA1) todos os grupos, aos sete meses de idade, apresentaram densidade semelhante desse marcador $\left(F_{(3,12)}=\right.$ 2,83, $P=0,12$ ) (Figura 14A). Por outro lado, na região de células granulares do giro denteado $(\mathrm{GrDG})$, foi verificado interação significativa nos parâmetros avaliados $\left(\mathrm{F}_{(3 \text {, }}\right.$ 12) $=11,75, \mathrm{P}=0,01)$, uma vez que o grupo TG-AE, apresentou uma redução de $21,7 \%$ na densidade dos corpos neuronais quando as regiões ventral e dorsal foram comparadas $(0,60 \pm 0,03 \mathrm{ROD})$ (Figura 14B).

Figura 14 - Quantificação de corpos neuronais nas regiões PyCA1 (A) e GrDG (B) do hipocampo de animais WT e TG, aos 7 meses de idade, utilizando a coloração Cresil-violeta

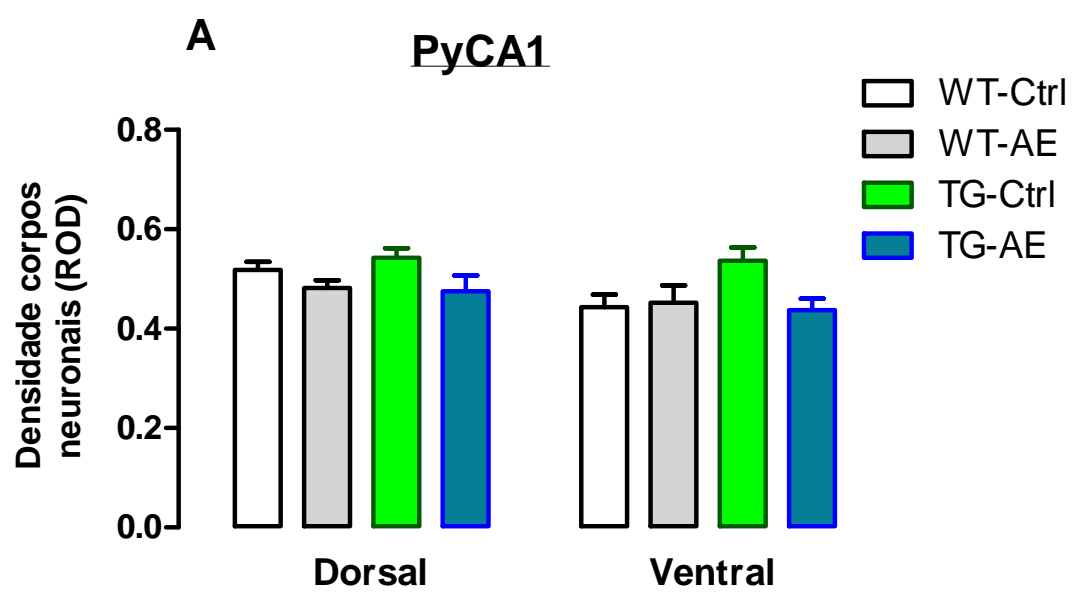

$\left[\mathrm{F}_{(3,12)}=2,83, \mathrm{P}=0,12\right]$

B

GrDG

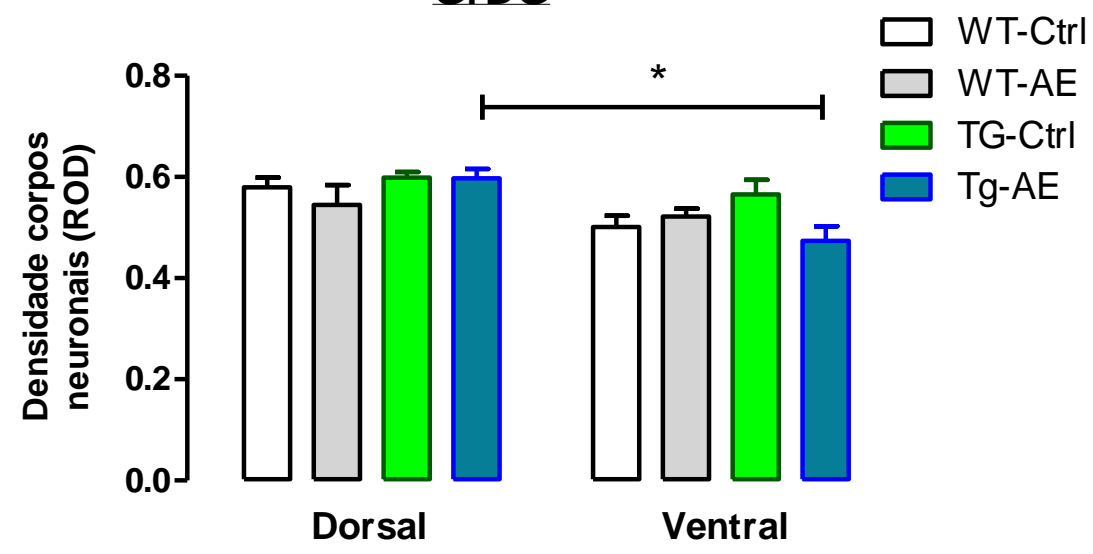

$\left[\mathrm{F}_{(3,12)}=11,75, \mathrm{P}=0,005\right]$

Os histogramas e barras verticais são as médias \pm erro-padrão das médias. * $: \mathrm{P}<0,05$. 


\subsubsection{Quantificação das placas $\beta$-amilóide}

Na quantificação das placas $\beta$-amilóide dos animais com 7 meses de idade foi observado que os animais WT, estimulados ou não, apresentaram placas senis (WTCtrl: 0,96 \pm 0,34 placas/corte; WT-AE: 0,75 $\pm 0,25$ placas/corte). Mas este número é significativamente menor que o encontrado nos animais TG (TG-Ctrl: 2,22 \pm 0,26 placas/corte; TG-AE: 1,99 \pm 0,34 placas/corte) (Figura 15A). A submissão dos animais ao ambiente enriquecido não alterou o valor proporcional das placas entre os grupos (Figura 15A).

Na análise da distribuição das mesmas, ao longo da localização dorso-ventral, foi verificado que as placas $\beta$-amilóide dos animais transgênicos se concentraram na região dorsal do hipocampo (TG-Ctrl: 23,25 \pm 5,17 placas; TG-AE: 21,50 \pm 6,61 placas), sendo um número significativamente maior do que aquele encontrado na porção ventral (TG-Ctrl: 1,00 \pm 0,71 placas; TG-AE: 2,75 $\pm 0,75$ placas). A estimulação em ambiente enriquecido não alterou a densidade de placas no hipocampo de animais WT ou TG de 7 meses de idade (Figura 15B).

Análises do córtex e da amígdala foram realizadas, mas não houve a presença de placas nessas regiões. 
Figura 15 - Contagem de placas senis no hipocampo de animais WT e TG, aos 7 meses de idade, após coloração com Vermelho Congo
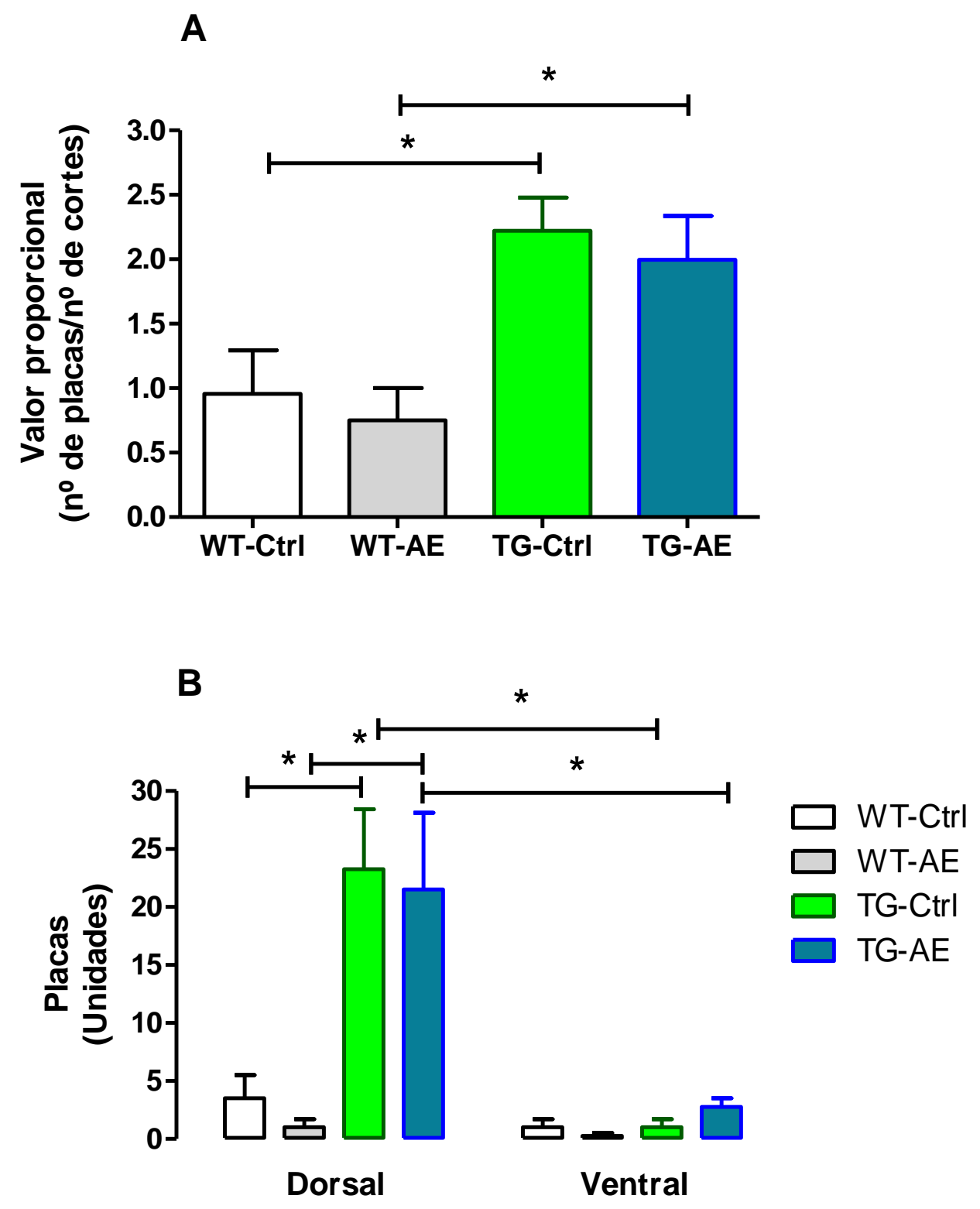

Os histogramas e barras verticais são as médias \pm erro-padrão das médias. $\mathbf{A}:{ }^{*}: \mathrm{P}<0,05 . \mathbf{B}:{ }^{*}: \mathrm{P}<$ 0,05 . 
$\mathrm{Na}$ figura 16 podemos observar imagens representativas das placas $\beta$ amilóide nos grupos analisados, WT-Ctrl, TG-Ctrl e TG-AE. Não foi possível obter imagem da placa em animais WT-AE, pois o tamanho da mesma não resultou em imagem nítida no momento da aquisição.

Figura 16 - Imagens representativas de cortes de cérebro de camundongos WT e TG, aos 7 meses de idade, corados com Cresil-violeta e Vermelho Congo

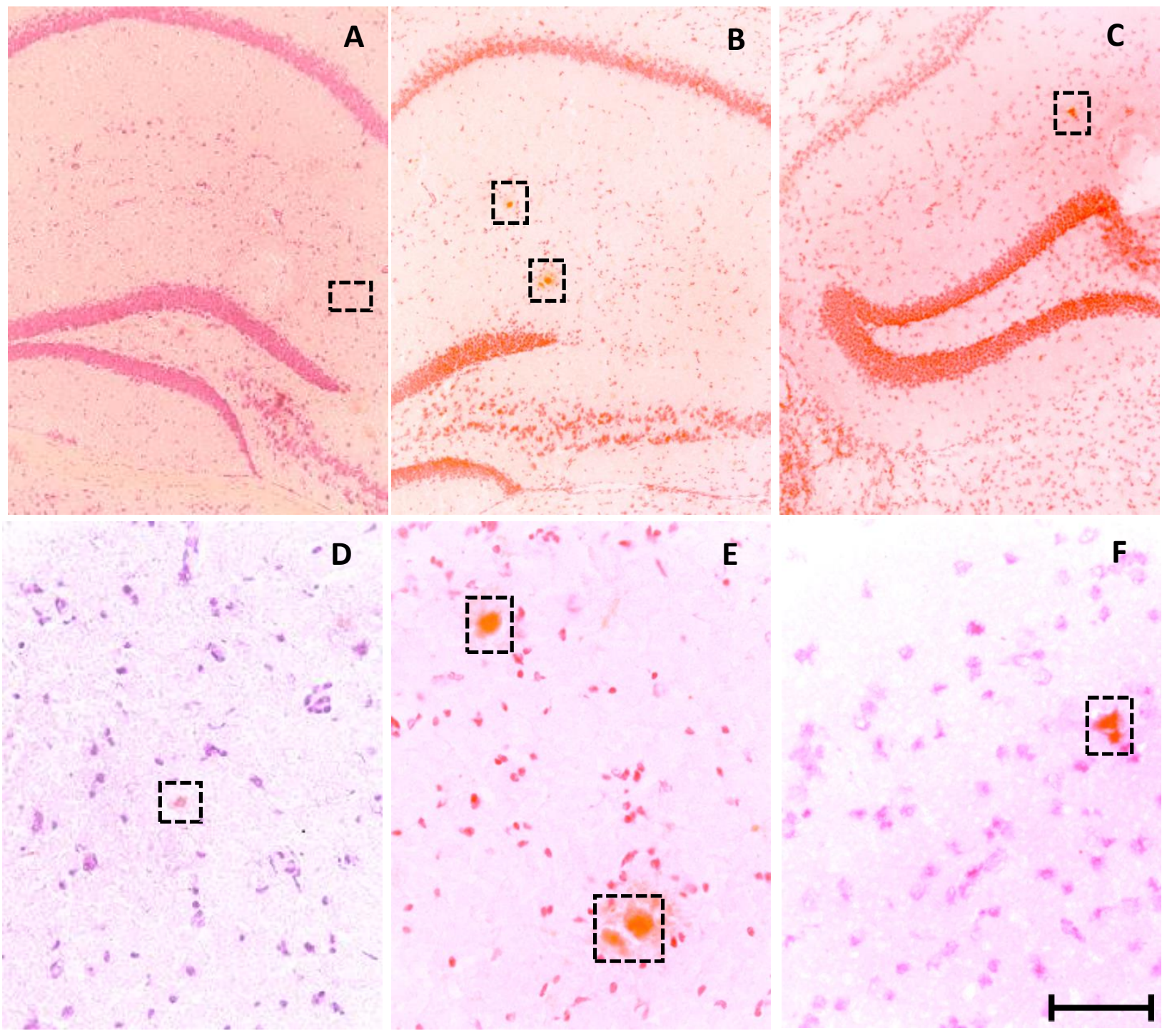

As figuras mostram cortes de hipocampo de animais WT controle ("A" e "D"), animais TG controle ("B" e "E") e animais TG que foram mantidos em AE ("C" e "F"). Os painéis apresentam um quadrado tracejado em torno da placa de $\beta A$. A barra de escala representa: $50 \mu \mathrm{m}$ para "A", "B" e "C"; $12,5 \mu \mathrm{m}$ para "D", "E" e "F". 


\subsection{Estudo comportamental e histológico dos animais de 8 a 12 meses}

\subsubsection{Avaliação da atividade motora}

Os grupos de animais WT-Ctrl, TG-Ctrl e TG-AE, de 8 a 12 meses de idade, não apresentaram alteração na deambulação ao longo do período avaliado e, também, não houve diferença significativa entre os grupos quando avaliados dentro de cada idade $\left(F_{(2,26)}=0,62, P=0,65\right)$ (Figura 17).

Figura 17 - Avaliação da deambulação dos animais WT e TG, aos 8, 10 e 12 meses de idade, em caixa de atividade motora

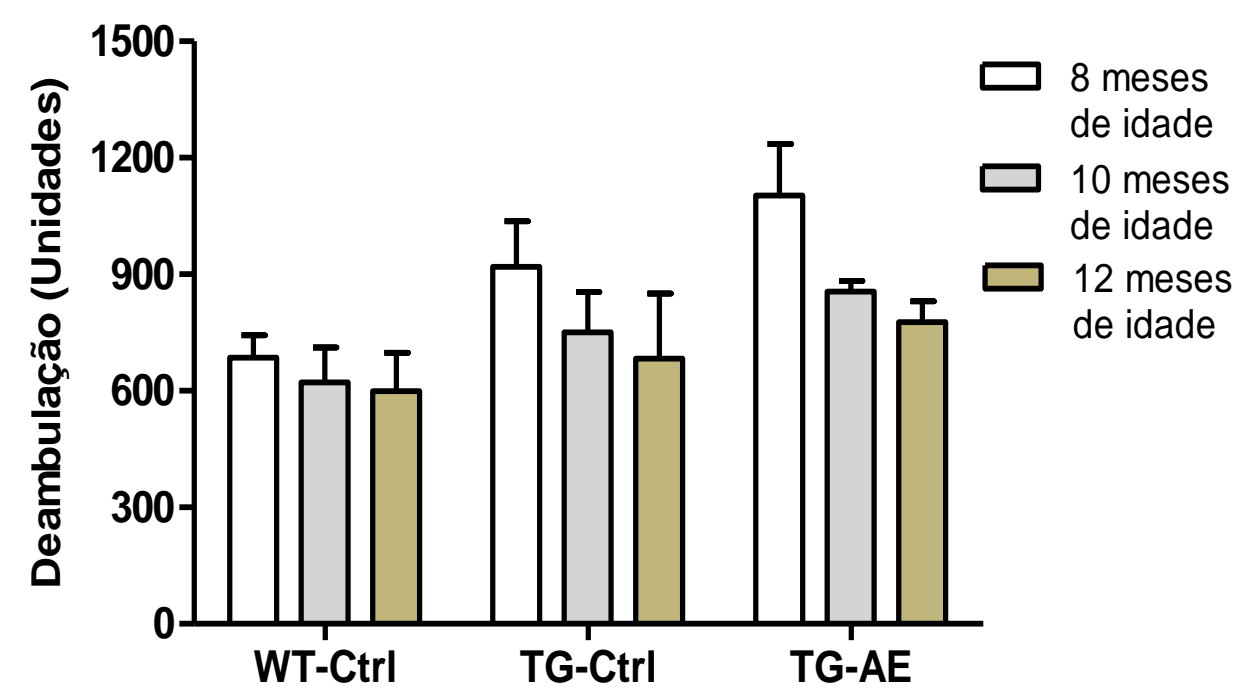

Os histogramas e barras verticais são as médias \pm erro-padrão das médias. 
Quando avaliada a exploração vertical desses animais, não houve alteração ao longo do período avaliado e assim como na deambulação, também não houve diferença significativa entre os grupos quando avaliados dentro de cada idade $\left(F_{(3,26)}\right.$ $=0,83, \mathrm{P}=0,52)$ (Figura 18).

Figura 18 - Avaliação da exploração vertical dos animais WT e TG, aos 8, 10 e 12 meses de idade, em caixa de atividade motora

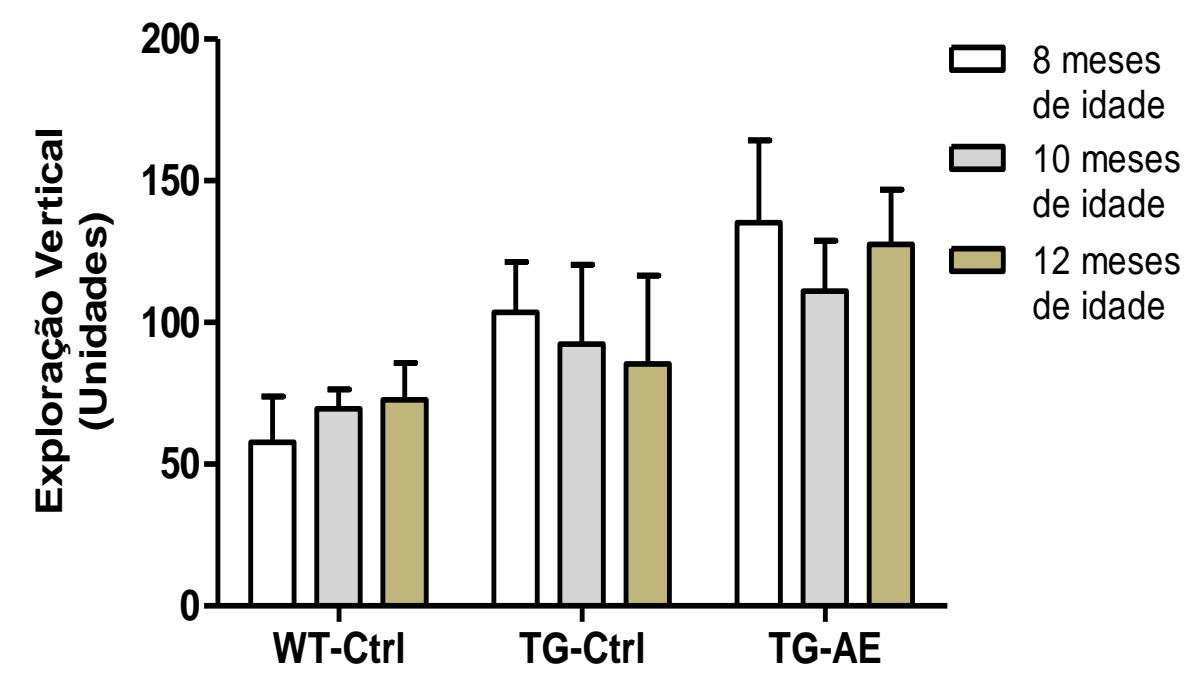

Os histogramas e barras verticais são as médias \pm erro-padrão das médias. 


\subsubsection{Avaliação da memória espacial}

A avaliação da memória espacial em labirinto de Barnes para esse grupo de animais, ao contrário dos animais de 3 a 7 meses de idade, foi realizada apenas aos 12 meses de idade, com um teste de memória de longa duração uma semana após o quinto dia de teste.

$\mathrm{Na}$ avaliação geral da memória espacial, aos cinco meses de idade, não foi verificada diferença do comportamento, independente da linhagem, tratamento ou tempo de observação $\left(F_{(2,120)}=1,91, P=0,11\right)$. Entretanto, dentro de cada grupo, foi verificado que os animais WT-Ctrl, WT-AE e TG-Ctrl apresentaram uma diminuição significativa da latência para achar a caixa de escape ao longo dos cinco dias de observação.

Na primeira semana de teste os grupos WT-Ctrl e TG-AE apresentaram uma redução não significativa do tempo para achar a caixa de escape ao longo dos cinco dias de observação $\left(F_{(2,65)}=1,05, P=0,42\right)$. Por outro lado, foi verificado que 0 grupo TG-Ctrl, no 5을 dia de teste, apresentou uma diminuição significativa de 70,71\% do tempo que levava para achar a caixa de escape em relação ao $1^{\circ}$ dia de observação (103,30 \pm 25,66 s) (Figura 19A).

Quando avaliado o tempo que os animais levaram para achar a caixa de escape uma semana após o quinto dia de teste, não houve diferença significativa dentro de cada grupo e entre os grupos, mostrando que todos os grupos mantiveram a memória em relação à última vez que passaram pelo labirinto (Figura 19B). 
Figura 19 - Avaliação da latência para achar a caixa de escape dos animais WT e TG, aos 12 meses de idade, no labirinto de Barnes

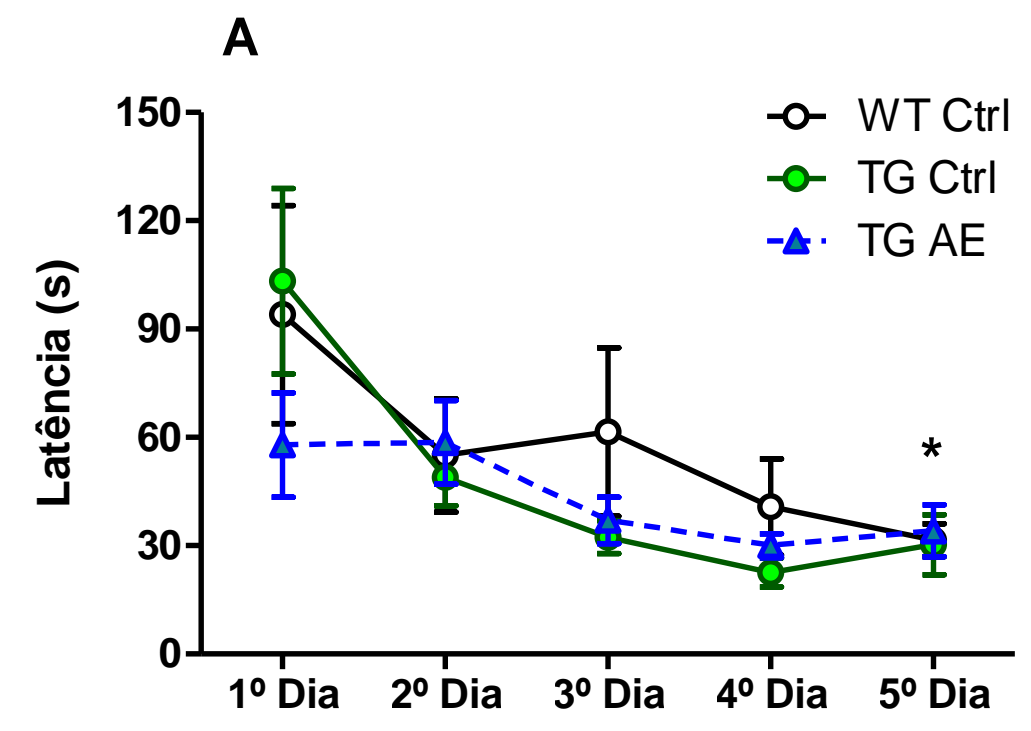

Blocos de duas provas

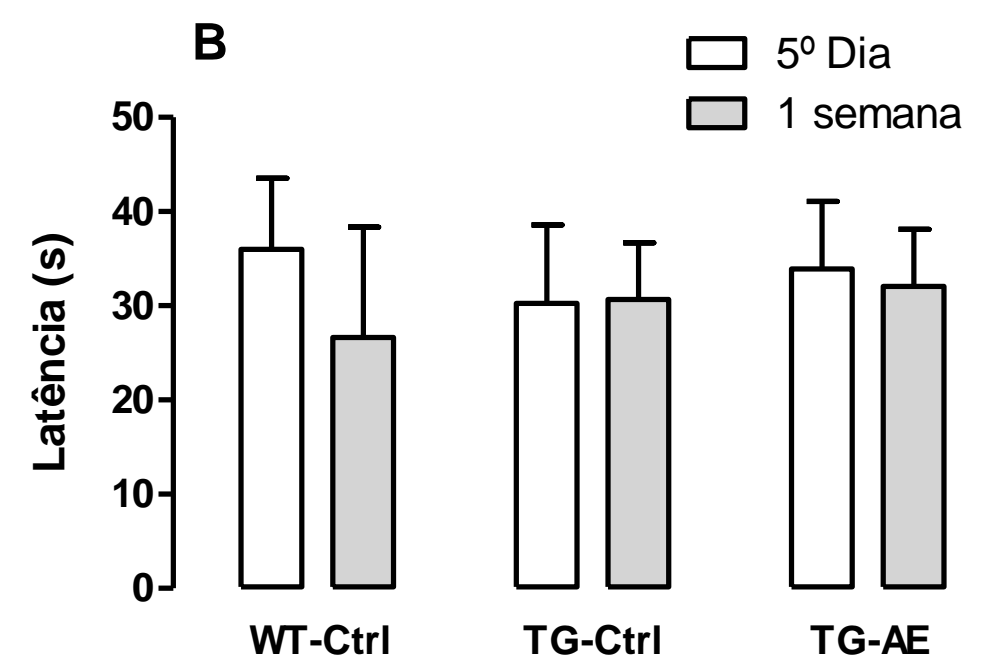

Os histogramas e barras verticais são as médias \pm erro-padrão das médias. A: *: P<0,05 entre dias 1 e 5 do grupo TG-Ctrl. 
Quando avaliado o número de erros para achar a caixa de escape, novamente os grupos WT-Ctrl e TG-AE não apresentaram diferença estatística entre o $5^{\circ}$ e $01^{\circ}$ dias de observação. Porém, no $5^{\circ}$ dia de avaliação, o grupo TG-Ctrl apresentou diminuição significativa de $76,50 \%$ do número de erros em relação ao $1^{\circ}$ dia de observação [8,17 $\pm 2,01$ erros, $\left.\left(F_{(2,65)}=3,09, P=0,003\right)\right]$ (Figura 20A).

Quando o número de erros foi avaliado uma semana após o quinto dia de teste, não houve diferença significativa dentro de cada grupo e entre os grupos, mostrando que todos os grupos mantiveram a memória em relação à última vez que passaram pelo labirinto (Figura 20B).

Figura 20 - Avaliação do número de erros cometidos pelos animais WT e TG para achar a caixa de escape, aos 12 meses de idade, no labirinto de Barnes

A

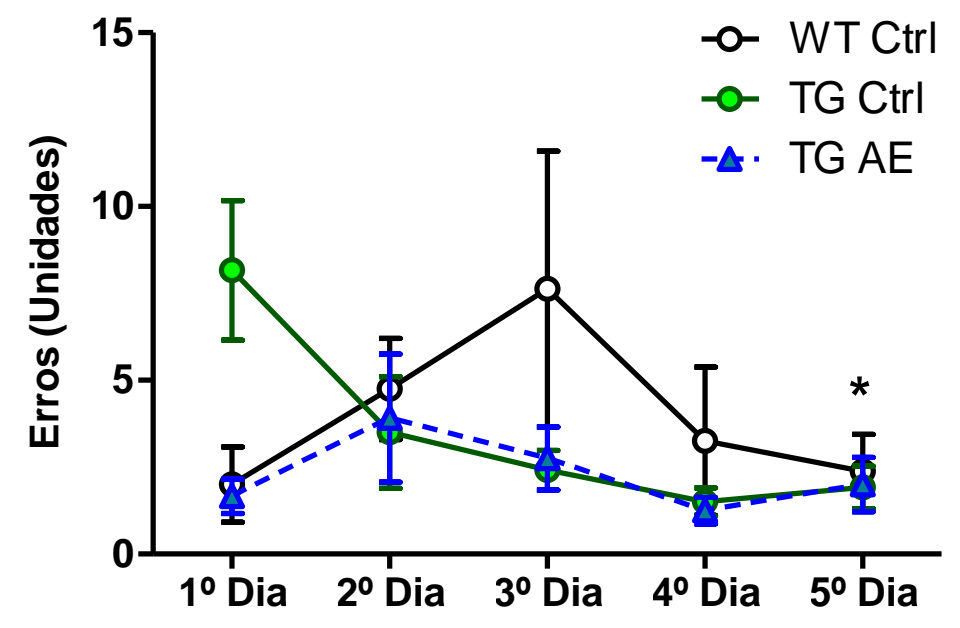

Blocos de duas provas

B

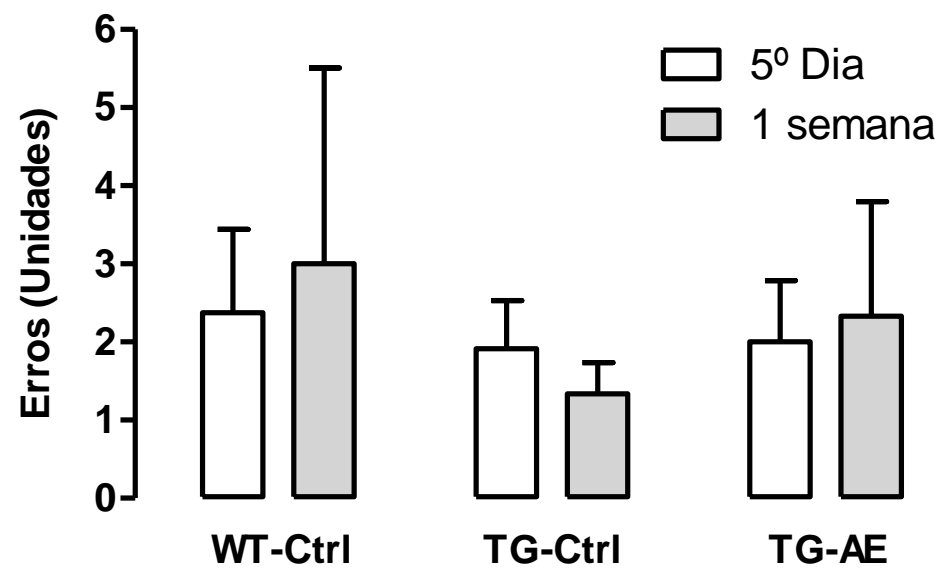

Os histogramas e barras verticais são as médias \pm erro-padrão das médias. $\mathbf{A}:{ }^{*}: \mathrm{P}<0,05$ entre dias 1 e 5 do grupo TG-Ctrl. 


\subsubsection{Avaliação da memória relacionada ao estímulo aversivo}

Na sessão de aquisição (SA), aos doze meses de idade, os animais WT-Ctrl, TG-Ctrl e TG-AE apresentaram latências semelhantes. A mediana geral das latências (com intervalos interquartis) na SA foi 21,30s $(14,13 / 32,90 \mathrm{~s})(\mathrm{n}=16)$.

$\mathrm{Na}$ avaliação da memória realizada $24 \mathrm{~h}$ após a SA, foi observado que todos os animais retiveram a informação adquirida [WT-Ctrl 300 s (300/300 s), TG-Ctrl 300 s (231,5/300 s) e TG-AE 296,1 s (273,5/300 s)], não havendo diferença entre os grupos (Figura 21).

Figura 21 - Avaliação da memória relacionada ao estímulo aversivo dos animais WT e TG, aos 12 meses de idade, em esquiva inibitória - Sessão de Aquisição (SA) e Teste $24 \mathrm{~h}$

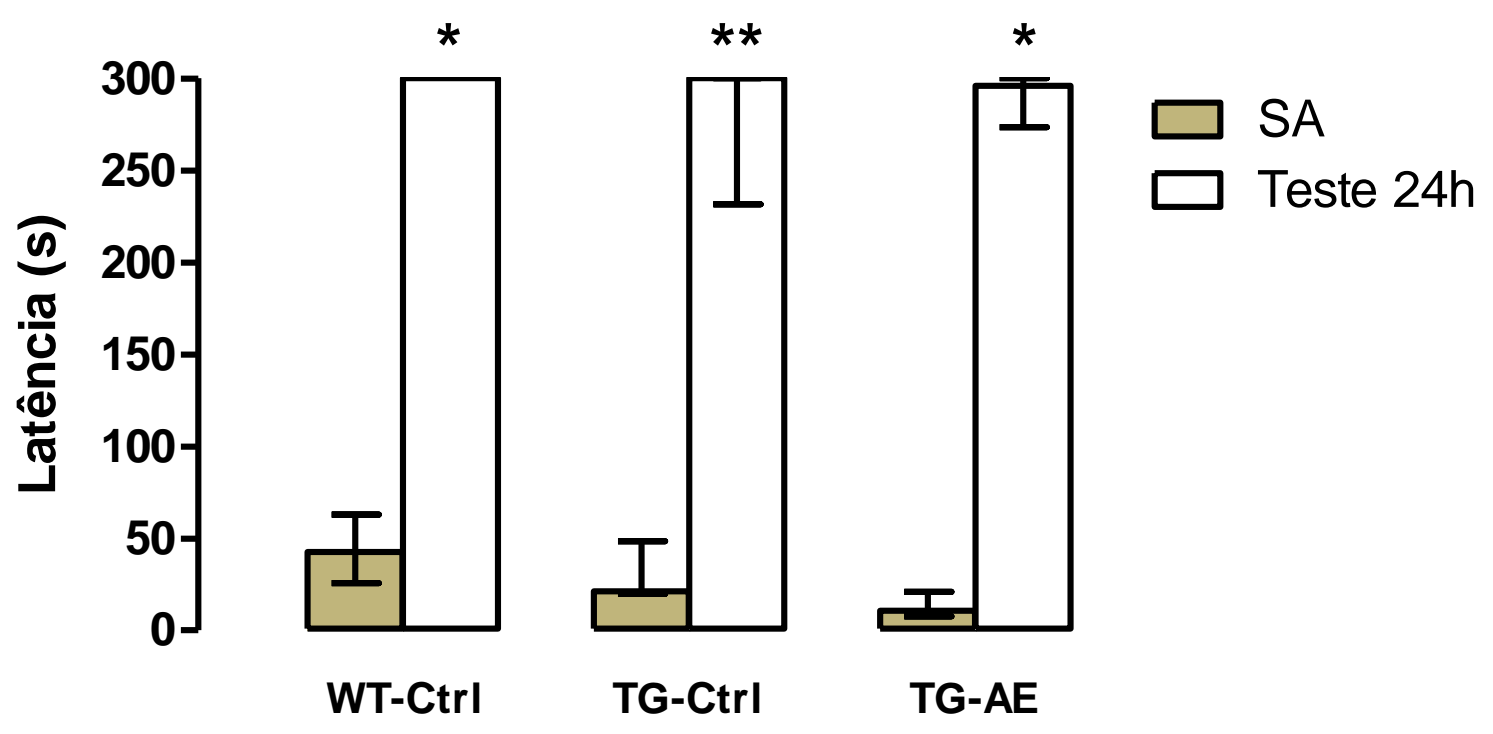

Os histogramas e barras verticais são as medianas e intervalos interquartis. ${ }^{*}: \mathrm{P}<0,05 ;{ }^{* *}$ : $\mathrm{P}<0,01$. 
Ao realizar um novo teste 7 dias após o teste de $24 \mathrm{~h}$, foi observado que a maioria dos animais se lembrou do choque [300 s (271,8/300 s)] $(n=16)$, permanecendo do lado claro do equipamento, não havendo diferença significante em relação ao teste de 24 h (Figura 22).

Figura 22 - Avaliação da memória relacionada ao estímulo aversivo dos animais WT e TG, aos 12 meses de idade em esquiva inibitória - Teste $24 \mathrm{~h}$ e Teste 7 dias

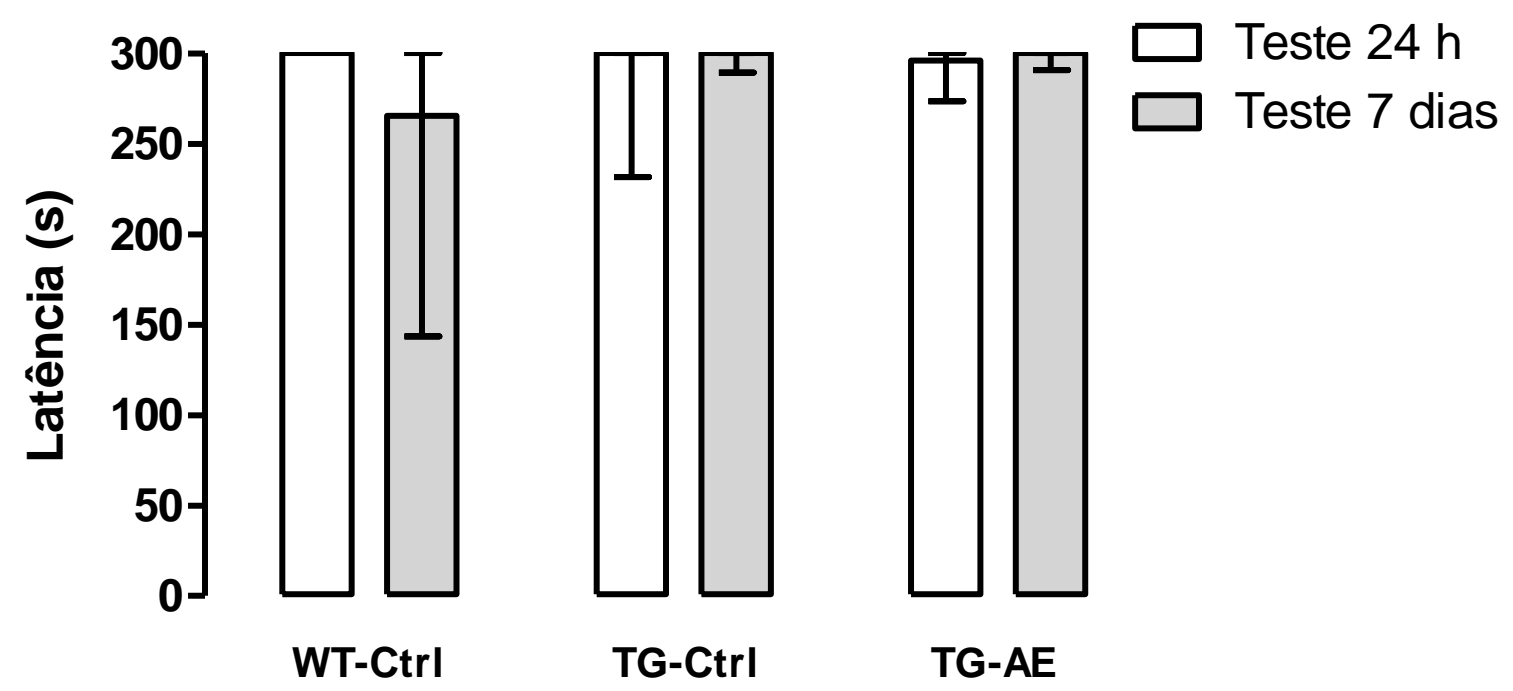

Os histogramas e barras verticais são as medianas e intervalos interquartis. 


\subsubsection{Quantificação das imunomarcações para Sinaptofisina}

$\mathrm{Na}$ avaliação da densidade de terminais pré-sinápticos por imunohistoquímica, foi verificado que todos os grupos, aos 12 meses de idade, apresentaram densidade semelhante desse marcador nas regiões hipocampais observadas (Figura 23).

Figura 23 - Quantificação de terminais pré-sinápticos em regiões do hipocampo, de animais WT e TG, aos 12 meses de idade, utilizando anticorpo antisinaptofisina

PyCA1
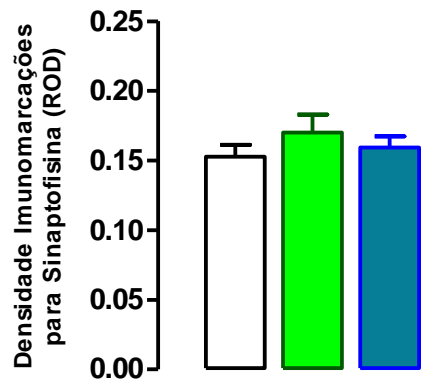

Dorsal

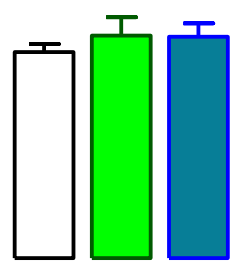

Ventral

$\left[F_{(2,16)}=0,45, P=0,76\right]$

GrDG

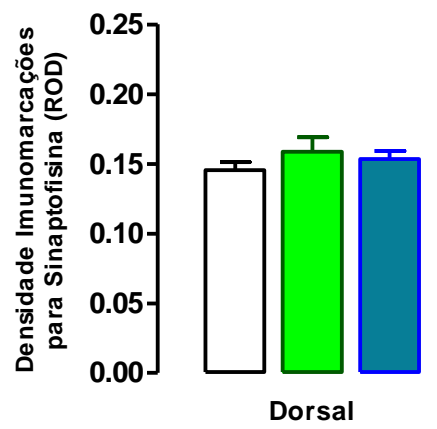

$\left[F_{(2,16)}=0,66, P=0,63\right]$

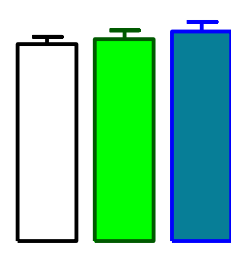

Ventral

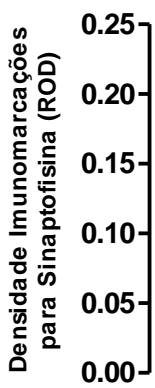

0.00

Dorsal

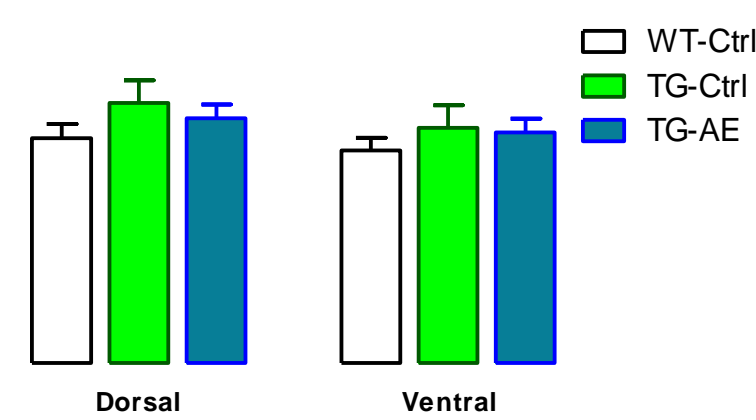

CA1

$\left[F_{(2,16)}=0,54, P=0,71\right]$

MoDG

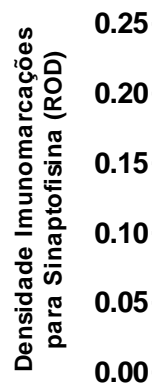

PoDG

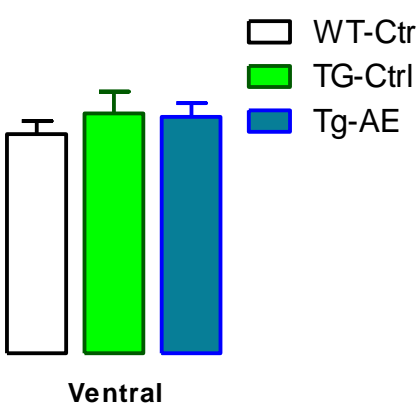

$\left[F_{(2,16)}=0,28, P=0,89\right]$

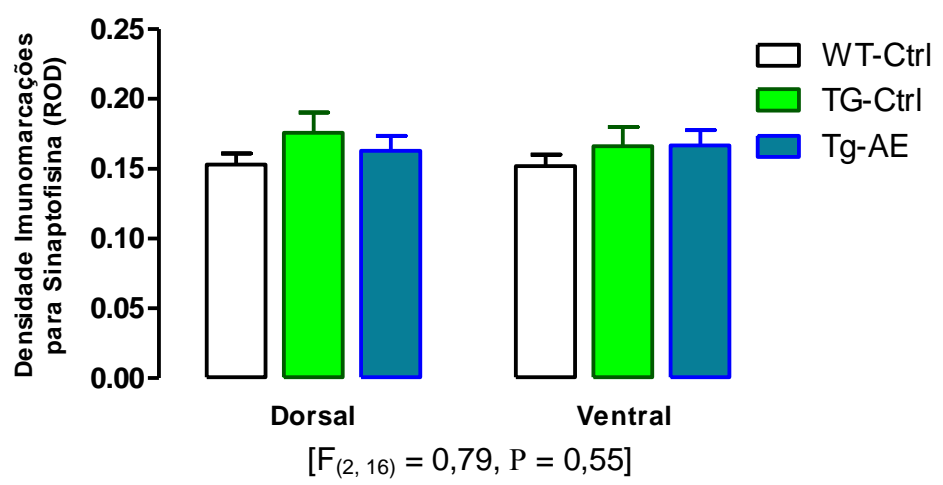

Os histogramas e barras verticais são as médias \pm erro-padrão das médias. 
Na região do córtex (Figura 24A) e da amígdala (Figura 24B), também foi verificado que todos os grupos, aos doze meses de idade, apresentaram densidade semelhante desse marcador.

Figura 24 - Quantificação de terminais pré-sinápticos no Córtex (A) e Amígdala (B) de animais WT e TG, aos 12 meses de idade, utilizando anticorpo antisinaptofisina

A

Córtex

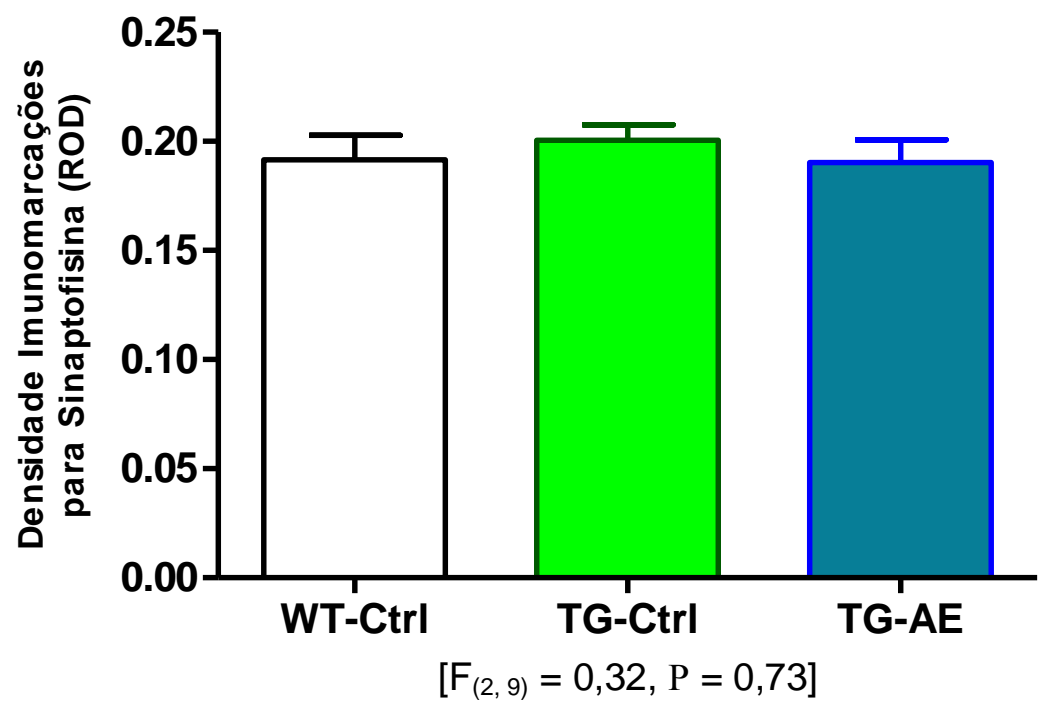

B

Amígdala

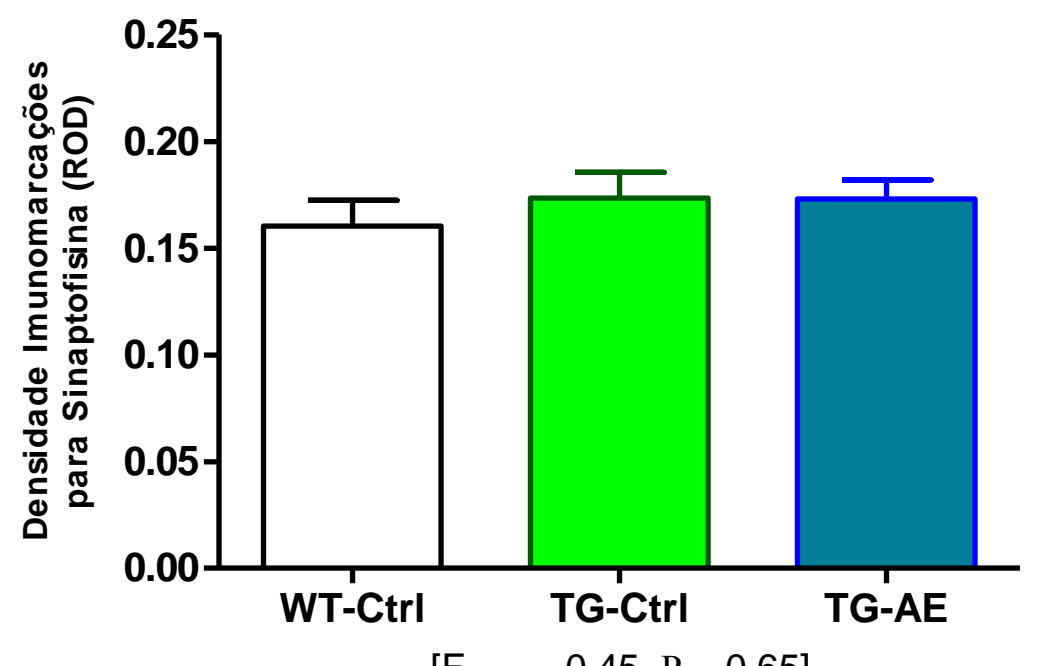

$\left[F_{(2,9)}=0,45, P=0,65\right]$

As barras verticais são as médias \pm erro-padrão das médias. 


\subsubsection{Análise da densidade de corpos neuronais}

$\mathrm{Na}$ avaliação da densidade de corpos neuronais foi verificado que na região de células piramidais do CA1 (PyCA1) todos os grupos, aos doze meses de idade, apresentaram densidade semelhante desse marcador $\left(F_{(4,16)}=0,90, P=0,48\right)$ (Figura 25A). O mesmo foi verificado na região de células granulares do giro denteado, $\operatorname{GrDG},\left(\mathrm{F}_{(4,16)}=0,63, \mathrm{P}=0,65\right)$ (Figura 25B).

Figura 25 - Quantificação de corpos neuronais nas regiões PyCA1 (A) e GrDG (B) do hipocampo de animais WT e TG, aos 12 meses de idade, utilizando a coloração Cresil-violeta

A

PyCA1

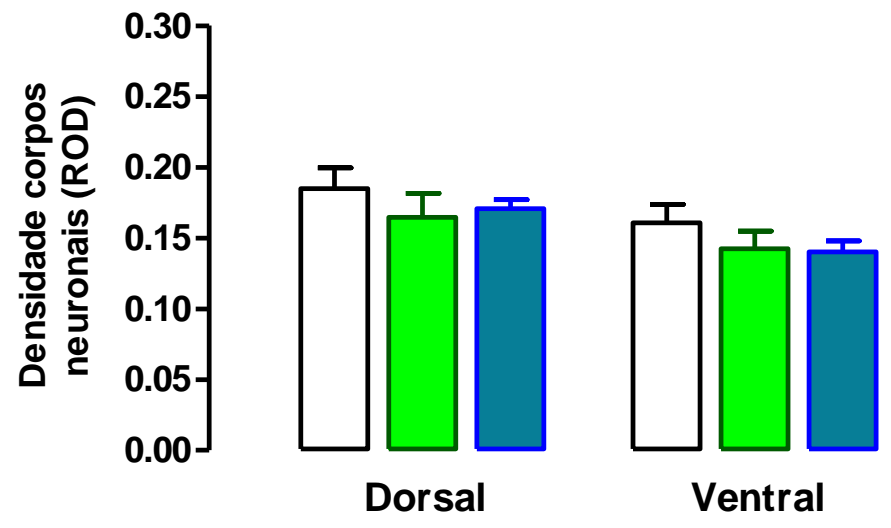

$\left[\mathrm{F}_{(2,16)}=0,90, \mathrm{P}=0,48\right]$

B

GrDG

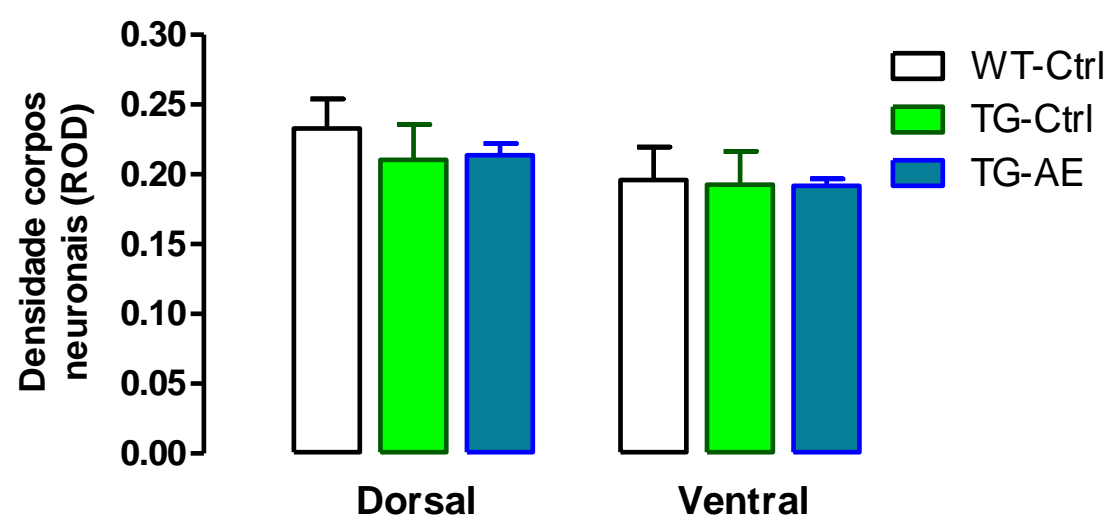

$\left[F_{(2,16)}=0,63, P=0,65\right]$

As barras verticais são as médias \pm erro-padrão das médias. 


\subsubsection{Quantificação das placas $\beta$-amilóide}

Assim como ocorreu nos animais de 7 meses, também foram encontradas placas de $\beta$-amilóide nos animais WT de 12 meses de idade (WT-CTrl: 1,33 $\pm 0,13$ placas/corte). Apesar de no grupo TG-Ctrl o número de placas ser evidentemente maior, não houve diferença significativa no valor proporcional de placas entre os grupos analisados $\left(F_{(2,9)}=3,18, P=0,09\right)$. A submissão dos animais $T G$ ao ambiente enriquecido reduziu em três vezes o número proporcional de placas (TGCtrl: 5,42 $\pm 2,17$ placas/corte; TG-AE: $1,79 \pm 0,15$ placas/corte). Porém, essa redução não foi estatisticamente significativa (Figura 6A).

$\mathrm{Na}$ comparação entre a distribuição de placas nas regiões dorsal e ventral do hipocampo foi observada redução de $85,18 \%$ na densidade de placas dos animais TG-AE, quando comparados aos animais TG-Ctrl, mostrando que a submissão de animais mais velhos ao ambiente enriquecido promoveu redução da densidade de placas a valores semelhantes aos dos animais WT-Ctrl. Porém, devido à grande dispersão dos valores no grupo TG-Ctrl, não houve diferença estatística. Por outro lado, ainda com relação ao grupo TG-Ctrl, foi verificada densidade significativamente maior das placas senis na região dorsal do hipocampo $(60,75 \pm 24,50$ placas $)$ comparativamente à região ventral $\left[9,00 \pm 3,76\right.$ placas, $\left.\left(\mathrm{F}_{(2,9)}=4,50, \mathrm{P}=0,04\right)\right]$. Nos outros grupos, a distribuição de placas nas duas regiões hipocampais foi semelhante.

Análises na região do córtex e da amígdala foram realizadas, mas não houve a presença de placas senis nessas regiões. 
Figura 26 - Contagem de placas senis no hipocampo de animais WT e TG, aos 12 meses de idade, após coloração com Vermelho Congo

A

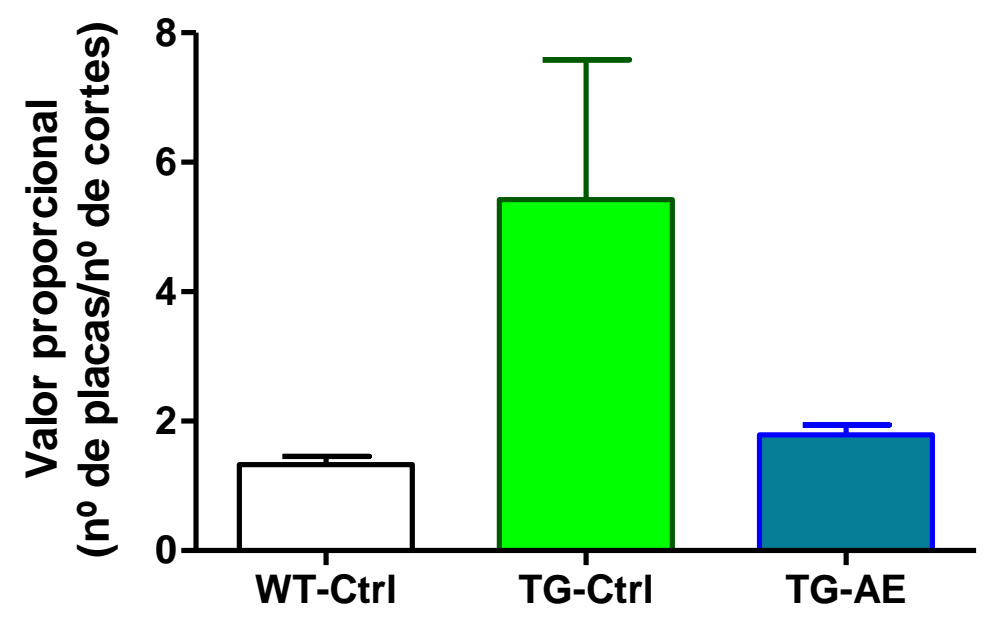

B

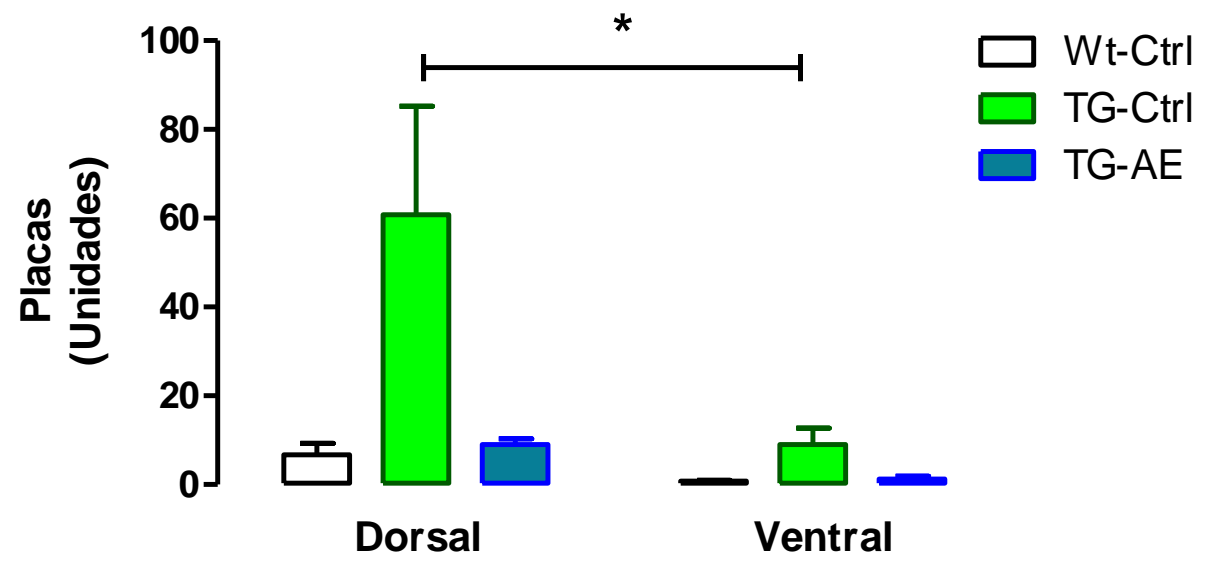

Os histogramas e barras verticais são as médias \pm erro-padrão das médias. *: $\mathrm{P}<0,05$.

$\mathrm{Na}$ figura 27 podemos observar imagens representativas das placas $\beta$ amilóide nos grupos analisados, WT-Ctrl, TG-Ctrl e TG-AE. Nas imagens 27-G e 27$\mathrm{H}$ podemos observar a degradação do giro denteado pelas placas $\beta$-amilóide. 
Figura 27 - Imagens representativas de cortes de cérebro de camundongos WT e TG, aos 12 meses de idade, corados com Cresil-violeta e Vermelho Congo

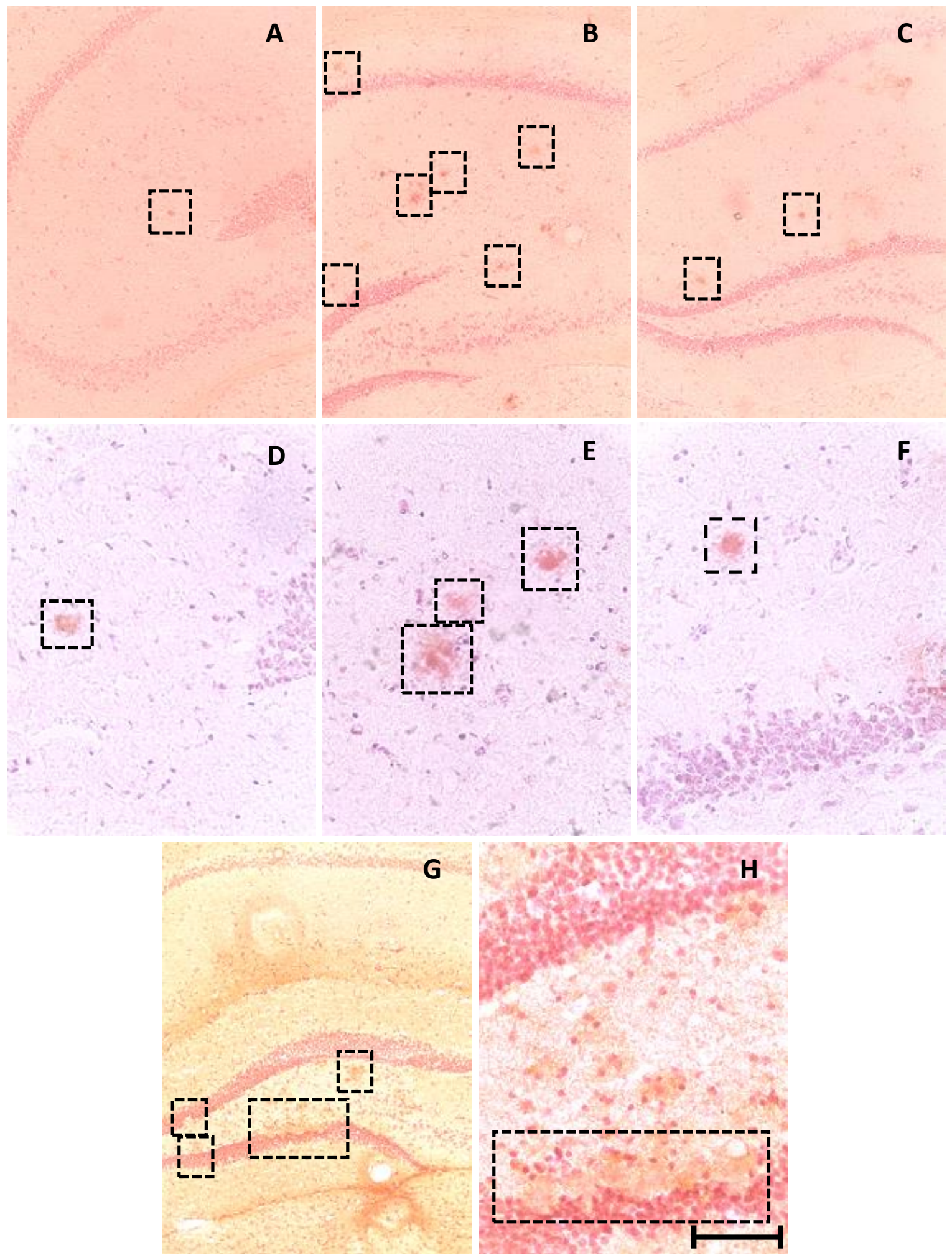

Imagens representativas de cortes de hipocampo de camundongos, corados com Cresil-violeta e Vermelho Congo. As figuras mostram cortes de hipocampo de animais WT controle ("A" e "D"), TG controle ("B", "E", "G" e "H") e animais TG que foram mantidos em AE ("C" e "F"). Os painéis apresentam um quadrado tracejado em torno da placa de $\beta A$. A barra de escala representa: $50 \mu \mathrm{m}$ para "A", "B", "C" e "G"; 12,5 um para "D", "E", "F" e "H". 


\subsubsection{Identificação e análise de emaranhados neurofibrilares}

$\mathrm{Na}$ análise por imunohistoquímica (Figura 28) e imunofluorescência (Figura 29) para a proteína tau hiperfosforilada, não foi possível identificar a presença de emaranhados neurofibrilares nas regiões do córtex e hipocampo dos animais em estudo.

Figura 28-A - Imagens representativas de cortes do córtex de camundongos WT e TG, aos 12 meses de idade. Imunohistoquímica revelada com DAB para TAU-5

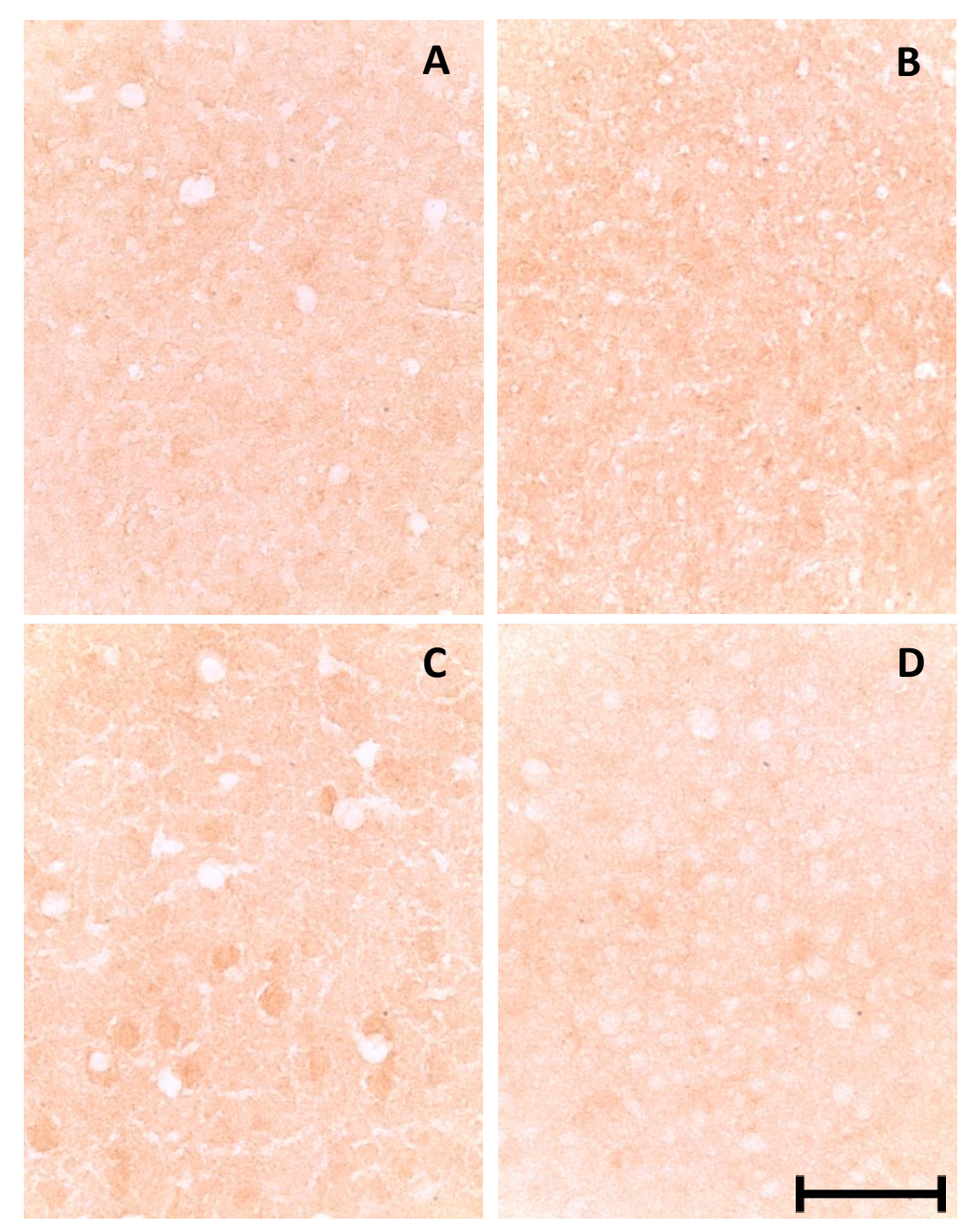

As figuras mostram cortes de córtex de animais WT-Ctrl ("A"), TG-Ctrl ("B") e animais TG-AE ("C"). No painel " $D$ " está representado o background do anticorpo testado. A barra de escala representa 12,5 $\mu \mathrm{m}$. 
Figura 28-B - Imagens representativas de cortes do hipocampo de camundongos WT e TG, aos 12 meses de idade. Imunohistoquímica revelada com DAB para TAU-5

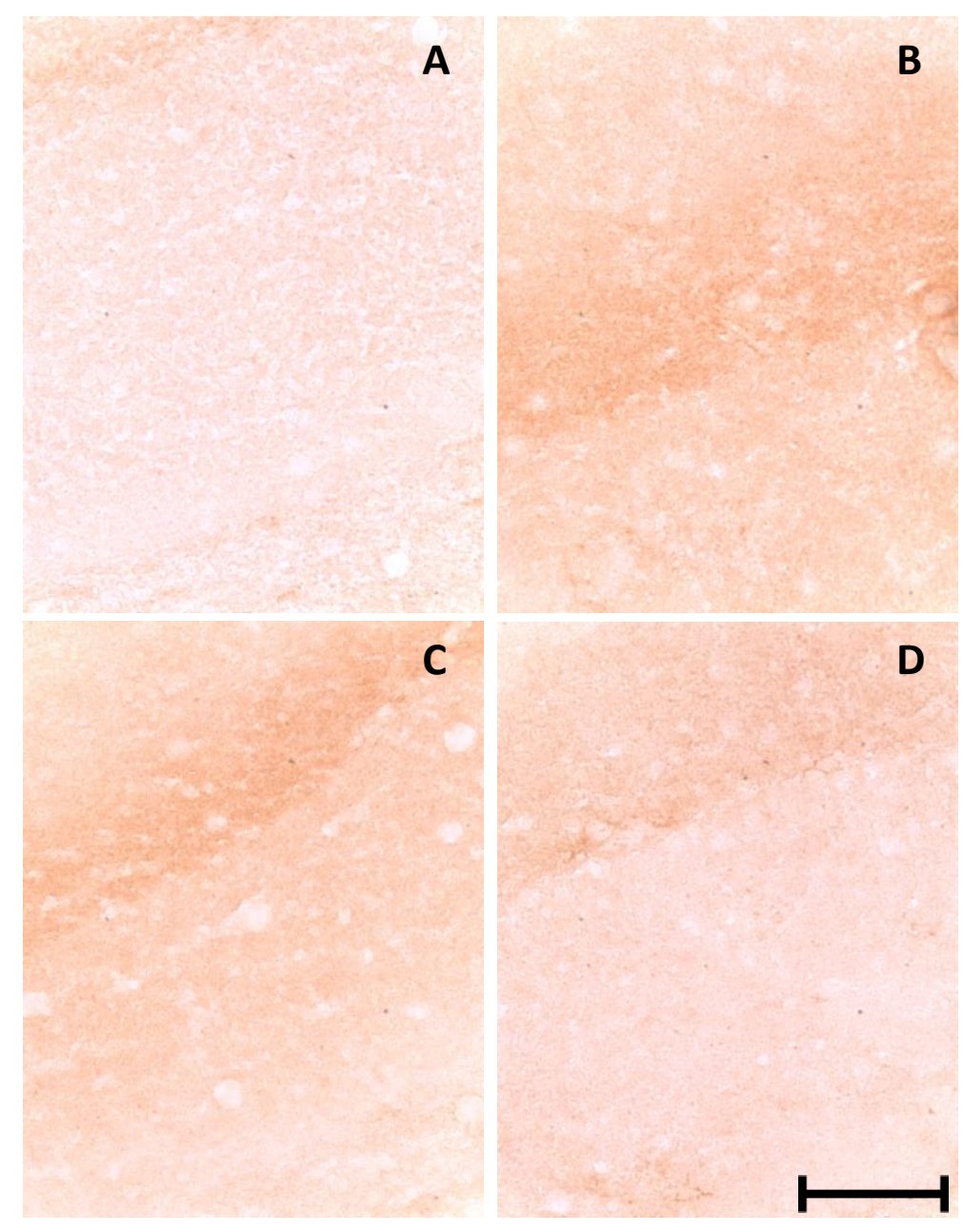

As figuras mostram cortes de hipocampo de animais WT-Ctrl ("A"), TG-Ctrl ("B") e animais TG-AE ("C"). No painel "D" está representado o background do anticorpo testado. A barra de escala representa $12,5 \mu \mathrm{m}$. 
Figura 29 - Imagens representativas de cortes do córtex e do hipocampo de camundongos WT e TG, aos 12 meses de idade. Imunofluorescência revelada com DAPI para TAU-5
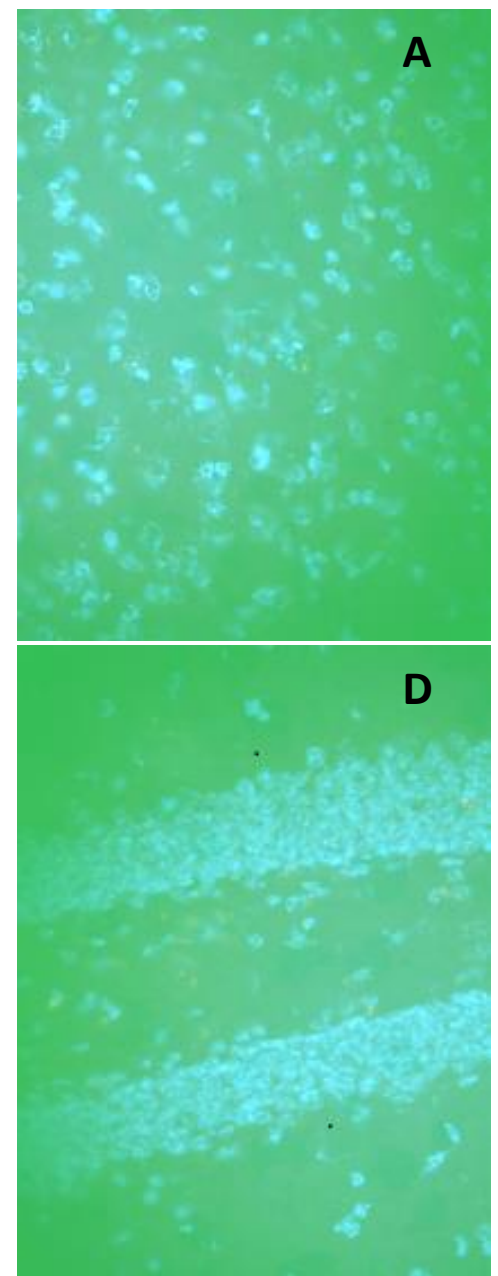

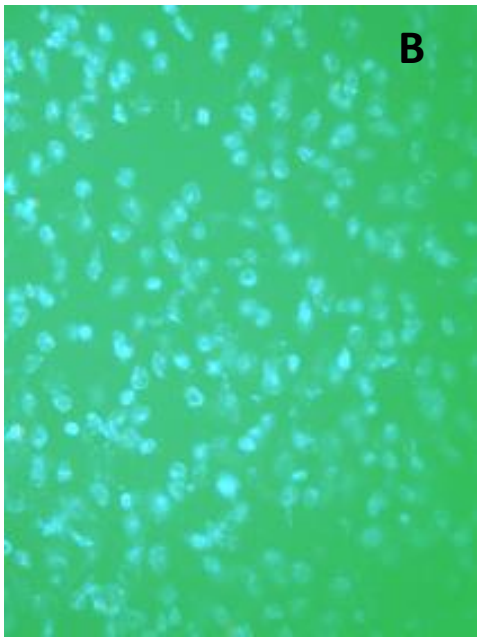

E

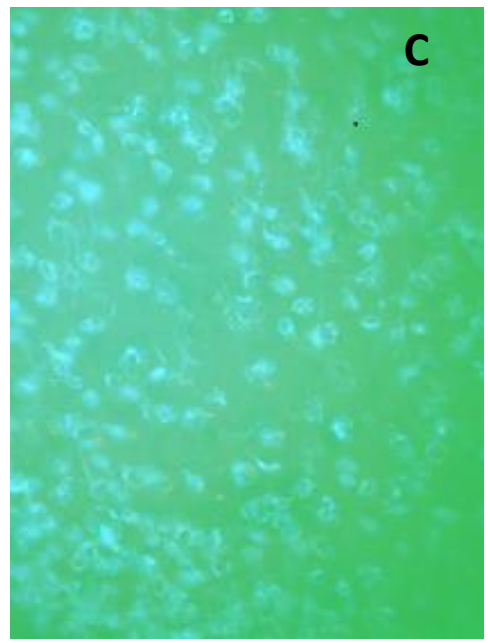

$\mathbf{F}$
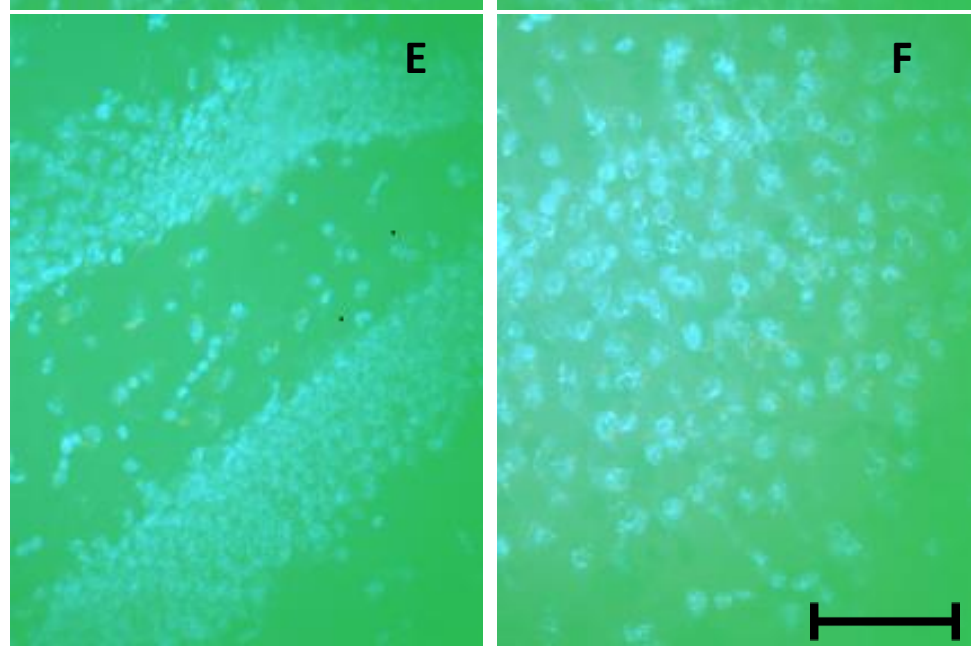

As figuras mostram cortes de córtex de animais WT-Ctrl ("A") e animais TG-Ctrl ("B") e cortes de hipocampo de animais WT-Ctrl ("D") e animais TG-Ctrl (“E”). Nos painéis "C" e "F" estão representados o background de córtex e hipocampo, respectivamente, para o anticorpo testado. Nos painéis " $D$ " e "E" as imagens correspondem à localização ântero-posterior $-2,18 \mathrm{~mm}$ em relação ao Bregma e no painel "F" a imagem corresponde à localização ântero-posterior -3,08 mm em relação ao Bregma, de acordo com Paxinos G e Franklin KBJ (2007). A barra de escala representa 12,5 $\mu \mathrm{m}$. 


\section{DISCUSSÃO}

Nos dias de hoje, com o avanço da tecnologia e da ciência, a expectativa de vida da população aumentou. Muitos países europeus têm grande parte de sua população composta por idosos. Ao analisar dados epidemiológicos de 1990 a 2005, é possível observar que a população europeia acima dos 60 anos aumentou de 19,2\% para 21,9\%, ou seja, de 84 milhões para 101 milhões (Eurostat, 2006). No Brasil, esta população é estimada em 13.632 .350 idosos entre 65 e 89 anos (Instituto Brasileiro de Geografia e Estatística - IBGE, 2010).

A velhice é uma fase do processo de envelhecimento que vem acompanhada, inevitavelmente, de declínio nos planos biológico e cognitivo. As células do sistema nervoso são afetadas e respondem a essa fase tanto quanto as células dos outros sistemas e passam a conviver com o aumento do estresse oxidativo, perturbação da homeostase energética, acúmulo de proteínas que causam dano celular e lesões nos seus ácidos nucléicos (Mattson, Magnus, 2006). Com essas mudanças no sistema nervoso central, uma das funções que podem ser afetadas é a memória.

A perda da memória na velhice não significa, necessariamente, em prejuízo na realização das atividades diárias, o que é, em contrapartida, observado nos casos de demência. Um dos tipos de demência que hoje tem como seu principal sintoma clínico a perda da memória é a doença de Alzheimer (DA), que se caracteriza pela deposição de placas do peptídeo beta-amilóide e emaranhados neurofibrilares em todo o cérebro, sobretudo no córtex e hipocampo, regiões importantes para a formação e consolidação de memórias.

Estudos epidemiológicos mostram que pessoas com alto nível de escolaridade apresentam menos risco de desenvolver a DA e, quando desenvolvem, sua evolução é mais lenta (Nitrini, 1999). Também está bem estabelecido na literatura que a estimulação cognitiva altera estruturalmente o sistema nervoso central de humanos e animais, isto é, ocorrem mudanças bioquímicas, alterações morfológicas das sinapses e da função neuronal, quando comparados a pessoas ou animais que não passam por estimulação (Jankowsky et al., 2005; Riley et al., 2005).

Compartilhando dessa ideia, nesse trabalho foi utilizado o ambiente enriquecido como estimulação cognitiva e física, em um período de 16 semanas, para animais transgênicos que superexpressam a PPA humana (PDGFB-APPSwInd, 
aqui denominados TG) e seus controles genéticos selvagens (C57BI/6, aqui denominados de WT) como uma estratégia não farmacológica para alterar a evolução do processo neurodegenerativo. Em termos experimentais, o ambiente é enriquecido em comparação às condições padrão de vida dos animais no laboratório, assim, a presença de objetos na caixa é o fator diferencial que causa alterações nos processos cerebrais dos animais (van Praag et al., 2000).

Em nossos experimentos, foram utilizados dois grupos de animais de idades diferentes, o primeiro de 3 a 7 meses, onde se testou o enriquecimento ambiental como uma forma de interferir no aparecimento das placas senis e o segundo de 8 a 12 meses de idade como tentativa de estabilizar a perda das funções cognitivas promovidas pelo quadro causado pelas placas. Os grupos foram compostos por animas WT e TG, controles (Ctrl) e estimulados em ambiente enriquecido (AE). No grupo de 8 a 12 meses de idade, o grupo WT-AE (que passaria pelo AE) não foi incluído, pois em ensaios preliminares, com animais de mesma idade (dados não apresentados), a estimulação em AE não promoveu alteração comportamental em relação aos animais WT-Ctrl.

Quando avaliada a memória espacial no labirinto de Barnes, os grupos WT de 5 meses de idade, estimulados (WT-AE) ou não (WT-Ctrl), apresentaram redução do tempo para achar a caixa de escape entre o primeiro e quinto dias que passaram pelo equipamento, mostrando que aprenderam a tarefa (Figura 8). Quando testados novamente, aos sete meses de idade, mostraram a manutenção desta memória (Figura 9). Portanto, o ambiente enriquecido não influenciou a memória espacial desses animais. De fato, em trabalho realizado por nosso grupo (Baraldi et al., submetido), bem como no estudo realizado por Harburger et al. (2007), a melhora da memória espacial devida ao estímulo cognitivo crônico, em animais C57BI/6, foi verificada somente quando os animais estavam mais velhos (11 meses e 21 meses, respectivamente).

O grupo WT-Ctrl que passou pelo labirinto de Barnes aos 12 meses, também apresentou diminuição do tempo para achar a caixa de escape, entre o primeiro e quinto dia de teste, mas devido à dispersão dos dados, esta redução não foi significativa (Figura 19A). Quando testado novamente uma semana após o quinto dia de treino, o grupo manteve a média de tempo, mostrando ter lembrado a tarefa (Figura 19B). Ao analisar o número de erros cometidos por este grupo antes de achar a caixa de escape, foi possível observar que os animais mantiveram-se dentro 
de uma média sem alterações significativas (Figura 20A), mostrando que mantiveram a memória da tarefa. Com esses dados, é possível inferir que, aos 12 meses de idade, os processos relacionados à memória espacial ainda estão preservados. Utilizando o mesmo equipamento, Barreto et al. (2010) verificaram uma perda significativa da memória espacial, em camundongos C57BL/6, quando estes estavam com 18 meses. Por outro lado, Calhoun et al. (1998), utilizando outro teste para avaliar memória espacial, o labirinto aquático de Morris, não observaram alteração da memória espacial, de animais semelhantes, aos 14 e aos 28 a 31 meses de idade. Esse fato deve-se, provavelmente, ao fato do maior estresse imposto pela natação nesta tarefa, comparativamente ao labirinto terrestre de Barnes (Patil et al., 2009).

Com relação aos animais transgênicos, foi observado que, aos 5 meses de idade, aqueles que viveram em ambiente enriquecido tiveram melhor desempenho do que seus controles na avaliação da memória espacial no labirinto de Barnes (Figura 8). Este fato pode estar relacionado à maior deambulação e exploração vertical apresentada por este grupo na caixa de atividade motora (Figuras 6 e 7). Aos 12 meses de idade, os animais TG, que também viveram em $A E$, levaram um menor tempo para achar a caixa de escape, entre os grupos avaliados, no primeiro dia de teste, mas sem diferença significativa de seu grupo controle (Figura 19A), a quantidade de erros também foi menor que a do grupo TG-Ctrl neste primeiro dia (Figura 20A), mostrando uma melhor performance do grupo estimulado. Na caixa de atividade motora esses animais, TG-AE, não apresentaram diferença significativa de seu grupo controle (Figuras 17 e 18). Essas observações vão ao encontro das publicadas por Jankowsky et al. (2005) que também observaram melhor desempenho em teste de memória espacial de camundongos transgênicos para DA (APPSwe e APPSwe/PS1dE9) e ratos não transgênicos que ficaram em ambientes enriquecidos.

Quando os animais TG do grupo adulto jovem completaram 7 meses de idade e passaram pelo teste do labirinto de Barnes novamente, não houve diferença entre os grupos TG-Ctrl e TG-AE no primeiro dia de observação, mas os animais do grupo TG-AE iniciaram a tarefa com latência maior para achar a caixa de escape (Figura 9), provavelmente porque não aprenderam a tarefa na última exposição. Da mesma forma, foi verificada uma diminuição na deambulação e exploração vertical deste grupo com relação aos cinco meses de idade (Figuras 6 e7), fato que também 
justificaria o maior tempo gasto no labirinto. Esta diminuição na deambulação, no entanto, não se tornou preocupante mediante o fato de que após o segundo dia de teste o desempenho do grupo TG-AE tornou-se semelhante aos demais grupos (Figura 9). Esse aumento da atividade locomotora em animais transgênicos para a PPA, jovens, com subsequente normalização com o envelhecimento, também foi observado por Rodgers et al. (2012). Quando os quatro grupos foram comparados (estimulados e não estimulados, transgênicos e não transgênicos) observou-se que o desempenho no labirinto no último dia de teste foi similar (Figura 9), assim como o grupo TG-Ctrl de 12 meses de idade, quando comparado ao seu controle genético de mesma idade, também apresentou desempenho semelhante no labirinto de Barnes (Figuras 19 e 20).

Quando avaliada a memória relacionada a estímulo aversivo, considera-se que o animal aprendeu a tarefa quando ele permanece maior tempo no lado claro do aparelho, apesar de sua preferência natural por lugares escuros. Nesse ensaio, foi observado que, aos 5 e aos 12 meses de idade, todos os grupos aprenderam a tarefa, isto é, no teste realizado $24 \mathrm{~h}$ após a sessão de aquisição, os animais permaneceram por mais tempo no compartimento claro da caixa (Figuras 10 e 21). Quando os animais adultos jovens completaram 7 meses de idade, o teste foi repetido, a memória dos animais dos dois grupos estimulados em ambiente enriquecido se manteve, diferente dos grupos que permaneceram em caixas-padrão (Figura 11). Já aos 12 meses de idade, todos os grupos mantiveram a memória com relação ao teste, quando testados 7 dias após o teste de 24h (Figura 22).

Vale lembrar que os animais adultos jovens foram estimulados por dois meses antes de serem submetidos ao teste e continuaram nesse ambiente por mais dois meses até o reteste 1 , enquanto os animais de 8 a 12 meses de idade foram estimulados por 4 meses e então submetidos ao teste. Sabe-se que 0 condicionamento de medo gera um comportamento que dura por muito tempo, uma vez que envolve um forte componente emocional (LeDoux, 2000). Mesmo assim, os animais adultos jovens, mantidos em caixas-padrão, não conseguiram reter a informação por dois meses, diferente do que foi observado com os dois grupos estimulados (WT-AE e TG-AE). Dessa forma, é possível sugerir que a manutenção de animais adultos jovens em $A E$ foi efetivo em manter o alerta e a atenção, bem como a memória relacionada a estímulo aversivo nos animais transgênicos, de forma semelhante aos animais WT, por 2 meses. Já nos animais mais velhos, todos 
os grupos foram capazes de lembrar por até uma semana da tarefa aprendida, mediante a intensidade do estímulo.

Com relação às análises teciduais dos animais, a quantificação dos terminais pré-sinápticos e dos corpos neuronais foi realizada na região do hipocampo, que se localiza no lobo temporal e está diretamente envolvido com a memória e orientação espacial, sendo o responsável pela transformação da memória de curto prazo em memória de longo prazo (Kandel, 2009; Izquierdo et al., 2008; Rossato et al., 2006). As áreas do hipocampo analisadas foram as do CA1 e do Giro Denteado que estão envolvidas no processo de aquisição, consolidação e evocação da memória (Cammarota et al., 2008; Clarke et al., 2010; Izquierdo et al., 2008). Sabe-se também que o hipocampo é uma das regiões cerebrais afetadas na DA acompanhado do córtex cerebral, sendo a área $\mathrm{CA} 1$, uma das primeiras a apresentar perda neuronal (Mattson, Magnus, 2006). No presente estudo foi verificado que a estimulação cognitiva em $A E$ por um tempo prolongado (16 semanas) na idade de 3 a 7 e 8 a 12 meses, em animais TG e WT não causou alteração estrutural significativa dessa área tanto na região dorsal, quanto na região ventral do hipocampo.

Da mesma forma, a análise dos terminais pré-sinápticos foi feita em outras duas áreas cerebrais: o córtex frontal que também é afetado na DA e está relacionado com atenção e armazenamento de memórias e a amígdala, estrutura envolvida no processamento da memória relacionada ao estímulo aversivo. Em ambas as regiões também não foram observadas alterações nessas estruturas (Figuras 13 e 24). Segundo Eckert et al. (2010), a falta de mudanças estruturais no cérebro após estimulação em longo prazo em ambiente enriquecido acontece e é devida à ação de mecanismos homeostáticos que mantêm a massa neuronal em limites restritos.

Os dados quanto a alterações na sinaptofisina para marcação de terminais pré-sinápticos ainda são muito variados. No envelhecimento natural em humanos foi verificado que a expressão dessa glicoproteína é reduzida em áreas como o hipocampo e córtex (Eastwood et al., 1994; Masliah et al., 1993) . Em roedores, estudos têm mostrado semelhante diminuição da sinaptofisina com 0 envelhecimento natural (Saito et al., 1994). Vários estudos têm mostrado a relação desta glicoproteína com memória espacial no labirinto aquático de Morris, mostrando que a sinaptofisina pode estar envolvida no processo de aprendizado e melhora da 
memória espacial (Benice et al., 2006; Calhoun et al., 1998; Smith et al., 2000). King e Arendash (2002) mostraram aumento de sinaptofisina em um modelo animal para a DA, sugerindo um mecanismo compensatório da perda de plasticidade sináptica que ocorre na doença. Assim como Nakamura et al. (1999) e Saito et al. (1994) mostraram também um aumento nas marcações para esta glicoproteína após enriquecimento ambiental. Em contrapartida, Frick et al. (2003) não observaram alterações para sinaptofisina em animais C57BI/6, de sete meses de idade, que passaram pelo labirinto de Morris.

$\mathrm{Na}$ análise da quantidade de placas senis, na região do hipocampo, foi observada a presença em hipocampo de animais WT de 7 e 12 meses de idade (Figuras 15 e 26). Poucos estudos na literatura relatam o aparecimento dessas placas ou o acúmulo da forma solúvel do peptídeo $\beta$-amilóide em cérebro de ratos ou camundongos selvagens, sendo as razões do aparecimento desses achados ainda desconhecidas (Madhusudan et al., 2009; Rosario et al., 2009; Yoon et al., 2013).

O modelo TG utilizado nesse trabalho, Tg(PDGFB - APPSwlnd), expressa uma forma mutante da proteína precursora do amilóide humana (hPPA). Em nossas análises, esse modelo apresentou placas senis já aos 7 meses, em quantidade significativamente maior que em seu controle genético .

Entre os animais TG, não foi observada diferença no valor proporcional de no de placas $/ \mathrm{n}^{0}$ de cortes analisados entre os grupos controle e $A E$ aos 7 meses de idade (Figura 15A). Nos hipocampos de animais com 12 meses de idade houve uma redução de três vezes no valor proporcional de placas em animais mantidos em ambiente enriquecido, porém essa diferença não foi estatisticamente significativa provavelmente por causa do pequeno número de animais em cada grupo, o que determinou um aumento na dispersão dos dados (Figura 26A).

Quando analisado o valor total das placas, nas regiões dorsal e ventral do hipocampo, os animais TG-Ctrl e TG-AE, aos 7 meses, apresentaram uma maior densidade de placas na região dorsal do hipocampo, mas sem diferença entre eles dentro de cada porção (Figura 15B). Do mesmo modo, os animais TG-Ctrl de 12 meses, também apresentaram maior concentração de placas na região dorsal do hipocampo (Figura 26B). Há que se observar, ainda, que no grupo de animais de 12 meses de idade, os animais estimulados, apresentaram uma redução de $85,18 \%$ no valor total de placas na região dorsal do hipocampo, quando comparados ao seu 
grupo controle. Entretanto, novamente essa diferença não foi estatisticamente significativa provavelmente por causa da grande dispersão dos dados no grupo TGCtrl (Figura 26B).

Tentando estabelecer uma relação entre o desempenho comportamental dos animais TG-AE entre 3 e 7 meses de idade e a presença de placas senis na região dorsal do hipocampo, é possível inferir que a quantidade presente de placas $\beta$ amilóide nessa região dorsal do hipocampo não afetou o desempenho deste grupo no teste de memória relacionada ao estímulo aversivo, fazendo com que o grupo lembrasse o teste até dois meses após o teste de 24h. A região dorsal do hipocampo, local da presença das placas, está envolvida com o processamento do condicionamento de medo, sendo uma área importante para a aquisição e processamento desta memória (Wang et al., 2012; Zelikowsky et al., 2012). É sabido, também que essa região está envolvida com o processamento da memória espacial (Fanselow, Dong, 2010; Lee, Kesner, 2003). É possível, então, sugerir que o AE promoveu uma proteção das funções cognitivas e uma possível formação de reserva cognitiva que preveniu a perda dessa memória, como observado anteriormente por Petrosini et al. (2009) e Riley et al. (2005). Nesse contexto, o enriquecimento ambiental aparentemente promoveu um melhor funcionamento dos circuitos neuronais, sem aumento na quantidade de suas estruturas (como verificado no presente trabalho, com relação à densidade dos terminais pré-sinápticos e dos corpos neuronais), levando à manutenção da memória.

Estudos realizados em animais TG para a proteína precursora do amilóide (PPA) vão ao encontro das informações encontradas neste trabalho e têm sugerido que mesmo mediante a presença de placas senis não se observam alterações como perda de neurônios ou diminuição da sinaptofisina, mas o que se tem observado é a perda da efetividade da comunicação entre eles, principalmente nas regiões CA1 e giro denteado do hipocampo. A redução na eficácia funcional dos neurônios seria a causa do declínio cognitivo nesses animais, juntamente com o processo inflamatório causado pelas placas amilóides (Bero et al., 2012; Irizarry et al., 1997; Phinney et al., 1999; Takeuchi et al., 2000). Esse fato reforça a idéia de que o enriquecimento ambiental pode estar promovendo um melhor funcionamento dos circuitos neuronais, sem aumento na quantidade de suas estruturas em nossos animas TG de 7 meses de idade. 
Com relação aos animais de 12 meses, pudemos verificar um número de placas senis cerca de 3 vezes maior em relação aos animais de 7 meses $(60,75 \pm$ 24,50 placas e $23,25 \pm 5,17$ placas, respectivamente) e que o ambiente enriquecido levou a uma diminuição na quantidade dessas placas na região dorsal do hipocampo, mantendo os valores comparáveis aos do grupo WT-Ctrl. O grupo TGCtrl também apresentou maior concentração dessas placas na região dorsal do hipocampo. Ao analisar o comportamento dos animais TG aos 12 meses de idade, não houve diferença significativa entre eles no aprendizado e na memória de longa duração, avaliada sete dias após a primeira bateria de teste. A falta de diferença entre os grupos transgênicos, estimulados ou não, na memória relacionada ao estímulo aversivo, contrário ao que se observou nos animais jovens, pode ser devido ao curto tempo do reteste mediante a um estímulo tão intenso, dado que, quando observamos a diferença no grupo mais jovem, os animais tiveram um espaço de 2 meses entre as duas baterias de testes, o que é um tempo relativamente grande para o camundongo.

Seguindo essa linha de raciocínio, outros estudos tem mostrado que existem casos onde a presença das placas senis não está relacionada com quadro de demência ou déficit cognitivo (Grabowski, Damasio, 2004; Katzman et al., 1988; Price, Morris, 1999; Tomlinson et al., 1968). Estudos recentes mostraram que a forma oligomérica do $\beta$-amilóide, que seria a solúvel, apresenta grande potencial neurotóxico e pode afetar de forma significativa diferentes vias de sinalização celular (Haass, Selkoe, 2007; Pimplikar, 2009). Dessa forma, a presença dos oligômeros de $\beta$-amilóide e não somente das placas senis seria determinante para o aparecimento do déficit cognitivo nos animais transgênicos. Segundo Lesné et al. (2008), aos 12 meses de idade a quantidade de oligômeros tóxicos foi reduzida mediante o aumento das placas já formadas, indo ao encontro dos achados de Brunden et al. (2008), onde a formação das placas senis também coincidiu com a diminuição da quantidade dos oligômeros solúveis do local, de modo que seus efeitos nocivos também diminuem e a placa por si só não leva ao déficit cognitivo.

A falta de alterações na densidade de corpos neuronais em animais transgênicos para a PPA, como já citado anteriormente, vai ao encontro de dados relatados por outros grupos (Irizarry et al., 1997; Phinney et al., 1999; Takeuchi et al., 2000). Em animais C57BI/6, também foi observado que não há perda neuronal na região do hipocampo com o envelhecimento natural e que uma possível perda 
cognitiva dependeria de mecanismos mais complexos, como alterações no número e na morfologia das espinhas dendríticas, do que somente a perda neuronal (von Bohlen und Halbach, Unsicker, 2002; von Bohlen und Halbach et al., 2006).

$\mathrm{Na}$ avaliação da hiperfosforilação da tau por imunohistoquímica e imunofluorescência não foi possível verificar a presença dos novelos neurofibrilares, nos animais TG de 12 meses de idade (Figuras 28 e 29). Os dados literários quanto à indução da hiperfosforilação da tau pelo peptídeo $\beta$-amilóide são bastante variados. Alguns estudos demonstraram que as placas senis são primárias ao aparecimento dos novelos neurofibrilares e que oligômeros do peptídeo elevam a atividade da enzima GSK-3 $\beta$, levando a hiperfosforilação da tau (Chabrier et al., 2012; Hoshi et al., 2003; King et al., 2006; Stein et al., 2004). Outros mostraram que a toxicidade do $\beta$-amilóde é diretamente proporcional ao aparecimento da hiperfosforilação, sendo esta a responsável pelo efeito tóxico do peptídeo (Oddo et al., 2006; Roberson et al., 2007; Roberson et al., 2011).

No presente trabalho não foi possível estabelecer uma relação segura entre a presença de placas senis e formação de enovelamento neurofibrilares. De fato, somente a presença das placas senis parece não ser suficiente para a caracterização do déficit cognitivo, mas é necessária, também, a presença dos oligômeros do $\beta$-amilóide (que não foi quantificada no presente estudo) e formação de novelos neurofibrilares, para formar o quadro neurodegenerativo completo da DA (Giliberto et al., 2010).

A utilização do $A E$ como estimulação cognitiva em animais também tem suas limitações. A diversidade de resultados obtidos é gerada principalmente pela variabilidade dos animais. Não há como controlar a quantidade explorada por cada animal e o tempo de atividade física praticada por cada um (Redolat, Mesa-Gresa, 2012; Toth et al., 2011). Vale lembrar, também, que o ambiente enriquecido pode alterar funções fisiológicas e emocionais como ingestão de comida e água, níveis de corticosterona, ansiedade e agressividade (Benaroya-Milshtein et al, 2004; Toth et al., 2011; van Loo et al., 2002), que podem estar envolvidas e alterar o processo de cognição, o que tornaria necessário uma análise mais aprofundada dos efeitos do AE nesse modelo transgênico.

Mediante essas informações, podemos dizer que a manutenção de animais em ambiente enriquecido, de alguma forma, gera alterações fisiológicas e cognitivas. Porém, os resultados podem variar com o protocolo adotado e o modelo animal. 
Outro fato a ser considerado é que, de acordo com os resultados obtidos neste trabalho, o AE parece exercer um papel maior quando o organismo se encontra em um estado fisiológico anormal do que quando está em seu funcionamento normal, como foi mostrado que, mesmo diante da presença das placas senis, o desempenho do grupo TG-AE foi diferenciado nos testes comportamentais tanto aos 5 meses quanto aos 7 meses e 12 meses de idade. Outro exemplo desse efeito do AE em uma condição adversa foi que a estimulação não interferiu no aparecimento das placas quando nos referimos aos animais de 3 a 7 meses de idade, mas verificamos que quando os animais já possuíam essas placas, entre 8 e 12 meses de idade, o $A E$ foi efetivo em manter o número das mesmas de forma semelhante ao grupo WT-Ctrl. 


\section{CONCLUSÃO}

Após a estimulação em AE de animais transgênicos para a PPA humana, $\mathrm{Tg}$ (PDGFB - APPSwInd), comparativamente a seus controles selvagens (C57BI/6), por um período de 16 semanas e em duas idades diferentes (entre 3 e 7 meses e 8 e 12 meses de idade), podemos concluir que:

$\checkmark$ A manutenção de animais em AE por 4 meses foi efetiva em manter a memória relacionada a estímulo aversivo nos animais TG, de 3 a 7 meses de idade, de forma semelhante aos animais WT de mesma idade.

$\checkmark$ Nos animais TG mais velhos estimulados de 8 a 12 meses de idade, houve uma redução na densidade de placas senis na área dorsal do hipocampo, a níveis semelhantes aos do grupo WT-Ctrl de mesma idade (apesar dessa diferença não ser estatisticamente significativa).

$\checkmark$ Com 16 semanas de AE, as alterações antes visíveis e mensuráveis (4 a 6 semanas de estimulação), passam a não ser mais, devido a mecanismos homeostáticos que mantem a massa neuronal em volume restrito. O que se pode observar, de acordo com a literatura, é um melhor funcionamento das redes neuronais com prováveis alterações funcionais protetoras, que formam as reservas cognitivas verificadas tanto em humanos quanto em animais. 


\section{REFERÊNCIAS*}

Alzheimer's Association. Alzheimer's disease facts and figures, Alzheimer's \& Dementia. 2011;7(2):1-63.

American Psychiatry Association. Diagnostic and statistical manual of mental disorders. 4th ed. Washington, DC, 1994.

Arteni NS, Netto CA. Neuroplasticidade. In: Bases biológicas dos transtornos psiquiátricos. Kapazinski J, Quevedo J, Izquierdo I, editors. 2. ed. Porto Alegre: Artmed; 2004. Cap. 4. p. 71-82

Associação Médica Brasileira, Agência Nacional de Saúde Suplementar. Diretrizes Clínicas na saúde suplementar: doença de Alzheimer - diagnóstico. 2011.

Avila J, Lucas JJ, Perez M, Hernandez F. Role of tau protein in both physiological and pathological conditions. Physiol Rev. 2004;84(2):361-84.

Baker LD, Frank LL, Foster-Schubert K, Green PS, Wilkinson CW, McTiernan A, Plymate SR, Fishel MA, Watson GS, Cholerton BA, Duncan GE, Mehta PD, Craft S. Effects of aerobic exercise on mild cognitive impairment: a controlled trial. Arch Neurol. 2010;67(1):71-9.

Balducci C, Forloni G. APP transgenic mice: their use and limitations. Neuromolecular Med. 2011:13(2):117-37.

Baraldi T, Schöwe NM, Balthazar J, Monteiro-Silva KC, Albuquerque MS, Buck HS, Viel TA. Cognitive stimulation during lifetime and in the aged phase improved spatial memory, and altered neuroplasticity and cholinergic markers of mice. Submetido à revista: Journal of Experimental Gerontology em fevereiro 2013.

Barreto G, Huang TT, Giffard RG. Age-related defects in sensorimotor activity, spatial learning, and memory in C57BL/6 mice. J Neurosurg Anesthesiol. 2010; 22(3):214-9.

Benaroya-Milshtein N, Hollander N, Apter A, Kukulansky T, Raz N, Wilf A, Yaniv I, Pick CG. Environmental enrichment in mice decreases anxiety, attenuates stress responses and enhances natural killer cell activity. Eur J Neurosci. 2004; 20(5):13417.

Benice TS, Rizk A, Kohama S, Pfankuch T, Raber J. Sex-differences in age-related cognitive decline in C57BL/6J mice as-sociated with increased brain microtubuleassociated protein 2 and synaptophysin immunoreactivity. Neuroscience.2006;137(2):413-23.

\footnotetext{
* De acordo com: International Committee of Medical Journal Editors. [Internet]. Uniform requeriments for Manuscripts submitted to Biomedical Journal: sample references. [updated 2011 Jul 15]. Available from: http://www.icmje.org.
} 
Bero AW, Bauer AQ, Stewart FR, White BR, Cirrito JR, Raichle ME, Culver JP, Holtzman DM. Bidirectional relationship between functional connectivity and amyloid- $\beta$ deposition in mouse brain. J Neurosci. 2012;32(13):4334-40.

Bond M, Rogers G, Peters J, Anderson R, Hoyle M, Miners A, Moxham T, Davis S, Thokala $P$, Wailoo A, Jeffreys M, Hyde C. The effectiveness and cost-effectiveness of donepezil, galantamine, rivastigmine and memantine for the treatment of Alzheimer's disease (review of Technology Appraisal No. 111): a systematic review and economic model. Health Technol Assess. 2012;16(21):1-470.

Borchelt DR, Ratovitski T, van Lare J, Lee MK, Gonzales V, Jenkins NA, Copeland NG, Price DL, Sisodia SS. Accelerated amyloid deposition in the brains of transgenic mice coexpressing mutant presenilin 1 and amyloid precursor proteins. Neuron. 1997;19(4):939-45.

Bossy-Wetzel E, Schwarzenbacher R, Lipton SA. Molecular pathways to neurodegeneration. Nat Med. 2004;10(suppl):S2-S9.

Brandt $R$, Hundelt $M$, Shahani N. Tau alteration and neuronal degeneration in tauopathies: mechanisms and models. Biochim Biophys Acta. 2005;1739(2-3):33154.

Brasil. Ministério da Saúde. Secretaria de Atenção a Saúde (SAS). Portaria № 491, 23 de setembro de 2010.

Brun VH, Otnass MK, Molden S, Steffenach HA, Witter MP, Moser MB, Moser El. Place cells and place recognition maintained by direct entorhinal hippocampal circuitry. Science. 2002;296(5576):2243-6.

Brunden KR, Trojanowski JQ, Lee VM. Evidence that non-fibrillar tau causes pathology linked to neurodegeneration and behavioral impairments. J Alzheimers Dis. 2008;14(4):393-9.

Buchwalow I, Samoilova V, Boecker W, Tiemann M. Non-specific binding of antibodies in immunohistochemistry: fallacies and facts. Sci Rep. 2011;1: 28.

Calhoun ME, Kurth D, Phinney AL, Long JM, Hengemihle J, Mouton PR, Ingram DK, Jucker M. Hippocampal neuron and synaptophysin-positive bouton number in aging C57BL/6 mice. Neurobiol Aging. 1998;19(6):599-606.

Cammarota M, Bevilaqua LR, Rossato JI, Lima RH, Medina JH, Izquierdo I. Parallel memory processing by the CA1 region of the dorsal hippocampus and the basolateral amygdala. Proc Natl Acad Sci USA. 2008;105(30):10279-84.

Carson F. Histotechnology: A Self-Instructional Text. American Society for Clinical Pathology Press. 1990; p. 170-171.

Chabrier MA, Blurton-Jones M, Agazaryan AA, Nerhus JL, Martinez-Coria H, LaFerla FM. Soluble $a \beta$ promotes wild-type tau pathology in vivo. J Neurosci. 2012;32(48):17345-50. 
Chalmers DT, Dewar D, Graham DI, Brooks DN, McCulloch J. Differential alterations of cortical glutamatergic binding sites in senile dementia of the Alzheimer type. Proc Natl Acad Sci USA. 1990;87(4):1352-56.

Chaves ML, Camozzato AL, Godinho C, Piazenski I, Kaye J. Incidence of Mild Cognitive Impairment and Alzheimer Disease in Southern Brazil. J Geriatr Psychiatry Neurol. 2009;22(3):181-7.

Chen WS, Bear MF. Activity-dependent regulation of NR2B translation contributes to metaplasticity in mouse visual cortex. Neuropharmacology. 2007;52(1):200-14.

Chen KH, Reese EA, Kim HW, Rapoport SI, Rao JS. Disturbed Neurotransmitter Transporter Expression in Alzheimer Disease Brain. $J$ Alzheimers Dis. $2011 ; 26(4): 755-66$.

Clarke JR, Cammarota M, Gruart A, Izquierdo I, Delgado-García JM. Plastic modifications induced by object recognition memory processing. Proc Natl Acad Sci USA. 2010;107(6):2652-7.

Cleveland DW and Hoffman PN. Slow axonal transport models come full circle: evidence that microtubule sliding mediates axon elongation and tubulin transport. Cell. $1991 ; 67(3): 453-6$.

Dinamarca MC, Arrázola M, Toledo E, Cerpa WF, Hancke J, Inestrosa NC. Release of acetylcholinesterase (AChE) from beta-amyloid plaques assemblies improves the spatial memory impairments in APP-transgenic mice. Chem Biol Interact. 2008;175(1-3):142-9.

Duara R, Barker W, Loewenstein D, Bain L. The basis for disease-modifying treatments for Alzheimer's disease: the Sixth Annual Mild Cognitive Impairment Symposium. Alzheimers Dement. 2009;5(1):66-74.

Eastwood SL, Burnet PWJ, McDonald B, Clinton J, Harrison PJ. Synaptophysin gene expressio in human brain: a quantitative in situ hybridization and immunocytochemical study. Neuroscience. 1994;59(4):881-92.

Eckert MJ, Bilkey DK, Abraham WC. Altered Plasticity in Hippocampal CA1, But Not Dentate Gyrus, Following Long-Term Environmental Enrichment. J Neurophysiol. 2010;103(6):3320-9.

Eurostat - Populations Statistics. Luxembourg: Office for Official Publications of the European Communities; 2006.

Fanselow MS, Dong HW. Are the dorsal and ventral hippocampus functionally distinct structures? Neuron. 2010;65(1):7-19.

Farlow MR, Miller ML, Pejovic V. Treatment options in Alzheimer's disease: maximizing benefit, managing expectations. Dement Geriatr Cogn Disord. 2008;25(5):408-22. 
Faria LOM, Bella GP. Atualizações no tratamento não-farmacológico da doença de Alzheimer. Fisioter Bras. 2009;10(6):436-41.

Ferrari EAM, Toyoda MSS, Faleiros L. Plasticidade neural: relações com o comportamento e abordagens experimentais. Psic Teor Pesq. 2001;17(2):187-94.

Fendt M, Fanselow MS. The neuroanatomical and neurochemical basis of conditioned fear. Neurosci Biobehav Rev. 1999;23(5):743-60.

Frick KM, Stearns NA, Pan JY, Berger-Sweeney J. Effects of environmental enrichment on spatial memory and neurochemistry in middle-aged mice. Learn Mem. 2003;10(3):187-98.

Geldmacher DS. Treatment guidelines for Alzheimer's disease: redefining perceptions in primary care. Prim Care Companion J Clin Psychiatry. 2007;9(2): 113-21.

Giliberto L, D'Abramo C, Acker CM, Davies P, D'Adamio L. Transgenic expression of the amyloid-beta precursor protein-intracellular domain does not induceAlzheimer's Disease-like traits in vivo. PLoS One. 2010;5(7):e11609.

Glatt SL, Hubble JP, Lyons K, Paolo A, Tröster Al, Hassanein RE, Koller WC. Risk factors for dementia in Parkinson's disease: effect of education. Neuroepidemiology. 1996;15(1):20-5.

Goedert M. Tau protein and neurodegeneration. Semin Cell Dev Biol. 2004;15(1):459.

Goddard GV. Functions of the amygdala. Psychol. Bull. 1964;62:89-109.

Goodrich-Hunsaker NJ. Hunsaker MR, Kesner RP. The interactions and dissociations of the dorsal hippocampus subregions: how the dentate gyrus, CA3, and CA1 process spatial information. Behav Neurosci. 2008; 122(1):16-26.

Grobowski TJ, Damasio AR. Definition, clinical features and neuroanatomical basis of dementia. In: The neuropathology of dementia. 2nd ed. Cambridge University Press; 2004.

Grueninger F, Bohrmann B, Czech C, Ballard TM, Frey JR, Weidensteiner C, von Kienlin M, Ozmen L. Phosphorylation of Tau at S422 is enhanced by 73 Abeta in TauPS2APP triple transgenic mice. Neurobiol Dis. 2010; 37(2):294-306.

Guerriero Austrom M, Damush TM, Hartwell CW, Perkins T, Unverzagt F, Boustani M, Hendrie HC, Callahan CM. Development and implementation of nonpharmacologic protocols for the management of patients with Alzheimer's disease and their families in a multiracial primary care setting. Gerontologist. 2004;44(4):548-53.

Haass C, Selkoe DJ. Soluble protein oligomers in neurodegeneration: lessons from the Alzheimer's amyloid $\beta$-peptide. Nature Reviews/ Mol Cell Biol. 2007;8(2):101-12. 
Hansen RA, Gartlehner G, Webb AP. Efficacy and safety of donepezil, galantamine, and rivastigmine for the treatment of Alzheimer's disease: a systematic review and meta-analysis. Clin Interv Aging. 2008;3(2):211-25.

Harburger LL, Lambert TJ, Frick KM. Age-Dependent Effects of Environmental Enrichment on Spatial Reference Memory in Male Mice. Behav Brain Res. 2007;185(1):43-8.

Harlow H, McGaugh JL, Thompson RF. Psychology. San Francisco: albion, 1971.

Herrera E Jr, Caramelli P, Silveira AS, Nitrini R. Epidemiologic survey of dementia in a community-dwelling Brazilian population. Alzheimer Dis Assoc Disord. 2002;16(2):103-8.

Hogan DB, Bailey P, Black S, Carswell A, Chertkow H, Clarke B, Cohen C, Fisk JD, Forbes D, Man-Son-Hing M, Lanctôt K, Morgan D, Thorpe L. Diagnosis and treatment of dementia: 5. Nonpharmacologic and pharmacologic therapy for mild to moderate dementia. CMAJ. 2008;179(10):1019-26.

Howlett DR, Richardson JC, Austin A, Parsons AA, Bate ST, Davies DC, Gonzalez MI. Cognitive correlates of Abeta deposition in male and female mice bearing amyloid precursor protein and presenilin-1 mutant transgenes. Brain Res. 2004;1017(1-2):130-6.

Holmes A, Wrenn CC, Harris AP, Thayer KE, Crawley JN. Behavioral profiles of inbred strains on novel olfactory, spatial and emotional tests for reference memory in mice. Genes Brain Behav. 2002;1(1):55-69.

Hoshi M, Sato M, Matsumoto S, Noguchi A, Yasutake K, Yoshida N, Sato K. Spherical aggregates of beta-amyloid (amylospheroid) show high neurotoxicity and activate tau protein kinase l/glycogen synthase kinase-3beta. Proc Natl Acad Sci U S A. 2003;100(11):6370-5.

Hsia AY, Masliah E, McConlogue L, Yu GQ, Tatsuno G, Hu K, Kholodenko D, Malenka RC, Nicoll RA, Mucke L. Plaque-independent disruption of neural circuits in Alzheimer's Disease mouse models. Neurobiology. 1999;96(6):3228-33.

Instituto Brasileiro de Geografia e Estatística (IBGE). Censo IBGE. Distribuição da população por sexo, segundo os grupos de idade. 2010. [2012 dez. 10]. Disponível em: http://www.censo2010.ibge.gov.br/sinopse/webservice/.

Irizarry MC, McNamara M, Fedorchak K, Hsiao K, Hyman BT. APPSw transgenic mice develop age-related $A$ beta deposits and neuropil abnormalities, but no neuronal loss in CA1. J Neuropathol Exp Neurol. 1997; 56(9):965-73.

Izquierdo I, Da Cunha C, Rosat R, Jerusalin-Sky D, Ferreira MBC, Medina JH. Neurotransmitter receptors involved in post-training memory processing by the amygdala, medial septum and hippocampus of the rat. Behav Neural Biol. 1992;58(1):16-26. 
Izquierdo I. Pharmacological evidence for a role of long-term potentiation in memory. FASEB J. 1994;8(14):1139-45.

Izquierdo I. Memória. Porto Alegre, RS: Artmed; 2002.

Izquierdo I. A arte de esquecer: cérebro e memória. 2. ed. Rio de Janeiro: Vieira \& Lent; 2010.

Izquierdo I, Cammarota M, Da Silva WC, Bevilaqua LR, Rossato JI, Bonini JS, Mello P, Benetti F, Costa JC, Medina JH. The evidence for hippocampal long-term potentiation as a basis of memory for simple tasks. An Acad Bras Cienc. 2008;80(1):115-27.

Jankowsky JL, Melnikova T, Fadale DJ, Xu GM, Slunt HH, Gonzales V, Younkin LH, Younkin SG, Borchelt DR, Savonenko AV. Environmental enrichment mitigates cognitive déficits in a mouse model of Alzheimer's Disease. The Journal of Neuroscience. 2005;25(21):5217-24.

Kandel ER. The biology of memory: a forty-year perspective. J Neurosci. 2009; 29(41):12748-56.

Kang J, Lemaire HG, Unterbeck A, Salbaum JM, Masters CL, Grzeschik $\mathrm{KH}$, Multhaup G, Beyreuther K, Müller-Hill B. The precursor of Alzheimer's disease amyloid A4 protein resembles a cell-surface receptor. Nature. 1987;325(6106):73336.

Katzman R, Terry R, DeTeresa R, Brown T, Davies P, Fuld P, Renbing X, Peck A. Clinical, pathological, and neurochemical changes in dementia: a subgroup with preserved mental status and numerous neocortical plaques. Ann Neurol. 1988;23(2):138-44.

Kikkawa M, Ishikawa T, Nakata T, Wakabayashi T, Hirokawa N. Direct visualization of the microtubule lattice seam both in vitro and in vivo. J Cell Biol. 1994;127(6 Pt 2):1965-71.

Kim JJ, Fanselow MS. Modality-specific retrograde amnesia of fear. Science. 1992;256(5057):675-7.

King DL, Arendash GW. Maintained synaptophysin immunore-activity in Tg2576 transgenic mice during aging: correlations with cognitive impairment. Brain Res. 2002;926(1-2):58-68.

King ME, Kan HM, Baas PW, Erisir A, Glabe CG, Bloom GS. Tau-dependent microtubule disassembly initiated by prefibrillar beta-amyloid. $\mathrm{J}$ Cell Biol. 2006;175(4):541-6.

Kobilo T, Liu QR, Gandhi K, et al. Running is the neurogenic and neurotrophic stimulus in environmental enrichment. Learn Mem. 2011;18(9):605-9. 
Kramer AF, Bherer L, Colcombe SJ, Dong W, Greenough WT. Environmental influences on cognitive and brain plasticity during aging. J Gerontol A Biol Sci Med Sci. 2004; 59(9):M940-M957.

LeDoux, JE. The amygdala. Current Biology. 2000; 17(20):868-74.

Lee I, Kesner RP. Time-dependent relationship between the dorsal hippocampus and the prefrontal cortex in spatial memory. J Neurosci. 2003; 23(4):1517-23.

Lee RKK, Wurtman RJ, Cox AJ, Nitsch NM. Amyloid precursor protein processing is stimulated by metabotropic glutamate receptors. Proc Natl Acad Sci USA. 1995;92(17):8083-7.

Lent R. Neurociência da Mente e do Comportamento. Rio de Janeiro: Guanabara Koogan; 2008.

Lesné S, Kotilinek L, Ashe KH. Plaque-bearing mice with reduced levels of oligomeric amyloid-beta assemblies have intact memory function. Neuroscience. 2008;151(3):745-9.

Lockhart IA, Mitchell SA, Kelly S. Safety and tolerability of donepezil, rivastigmine and galantamine for patients with Alzheimer's disease: systematic review of the 'real-world' evidence. Dement Geriatr Cogn Disord. 2009;28(5):389-403.

Loukavenko EA, Ottley MC, Moran JP, Wolff M, Dalrymple-Alford JC. Towards therapy to relieve memory impairment after anterior thalamic lesions: improved spatial working memory after immediate and delayed postoperative enrichment. Eur J Neurosci. 2007;26(11):3267-76.

Lovestone S, Graham N, Howard R. Guidelines on drug treatments for Alzheimer's disease. Lancet. 1997;350(9073):752-68.

Lynch DR, Guttmann RP. Excitotoxicity: Perspectives Based on N-Methyl-DAspartate Receptor Subtypes. J Pharmacol Exp Ther. 2002;300(3):717-23.

Madhusudan A, Sidler C, Knuesel I. Accumulation of reelin-positive plaques is accompanied by a decline in basal forebrain projection neurons during normal aging. Eur J Neurosci. 2009;30(6):1064-76.

Malenka RC, Bear MF. LTP and LTD: an embarrassment of riches. Neuron. 2004;44(1):5-21.

Maren S. Neurobiology of Pavlovian fear conditioning. Annu Rev Neurosci. $2001 ; 24: 897-931$. 
Martin SJ, Hoz L, Morris RG. Retrograde amnesia: neither partial nor complete hippocampal lesions in rats result in preferentialsparing 0 fremote spatial memory, even after reminding. Neuropsychologia. 2005; 43(4):60924.

Masliah E, Mallory M, Hansen L, DeTeresa R, Terry RD. Quantitative synaptic alterations in the human neocortex during normal aging. Neurology. 1993;43(1):1927.

Mattson MP. Pathways towards and away from Alzheimer's disease. Nature. 2004;430(7000):631-39.

Mattson MP, Magnus T. Ageing and neuronal vulnerability. Nat Rev Neurosci. 2006;7(4):278-94.

McEwen BS, de Leon MJ, Lupien SJ, Meaney MJ. Corticosteroids, the aging brain and cognition. Trends Endocrinol Metab. 1999;10(3):92-6.

McGowan E, Sanders S, Iwatsubo T, Takeuchi A, Saido T, Zehr C, Yu X, Uljon $S$, Wang R, Mann D, Dickson D, Duff K. Amyloid phenotype characterization of transgenic mice overexpressing both mutant amyloid precursor protein and mutant presenilin 1 transgenes. Neurobiology of Diseases. 1999;6(4): 231-44.

Meldrum BS. Glutamate as a neurotransmitter in the brain: review of physiology and pathology. J Nutr. 2000;130(4S Suppl):1007S-15S.

Meunier M, Bachevalier J, Murray EA, Málková L, Mishkin M. Effects of aspiration versus neurotoxic lesions of the amyg-dala on emotional responses in monkeys. Eur J Neurosci. 1999;11(12):4403-18.

Minger SL, Esiri MM, McDonald B, Keene J, Carter J, Hope T, Francis PT. Cholinergic deficits contribute to behavioral disturbance in patients with dementia. Neurology. 2000;55(10):1460-7.

Miyakawa T, Yared E, Pak JH, Huang FL, Huang KP, Crawley JN. Neurogranin null mutant mice display performance deficits on spatial learning tasks with anxiety related components. Hippocampus. 2001;11(6):763-75.

Morris RG, Garrud P, Rawlins JN, O'Keefe J. Place navigation impaired in rats with hippocampal lesions. Nature. 1982;297(5868):681-3.

Morris RG, Anderson E, Lynch GS, Baudry M. Selective impairment of learning and blockade of long-term potentiation by an N-methyl-D-aspartate receptor antagonist, AP5. Nature. 1986;319(6056):774-6.

Moser E, Moser MB, Andersen P. Spatial learning impairment parallels the magnitude of dorsal hippocampal lesions, but is hardly present following ventral lesions. J Neurosci. 1993:13(9):3916-25. 
Moser MB and Moser El. Distributed encoding and retrieval of spatial memory in the hippocampus. J Neurosci. 1998;18(18):7535-42.

Nakamura H, Kobayashi S, Ohashi Y, Ando S. Age-changes of brain synapses and synaptic plasticity in response to an enriched environment. J Neurosci Res. 1999;56(3):307-15.

Nitrini R. Epidemiologia da doença de Alzheimer no Brasil. Revista de Psiquiatria Clínica. 1999;26(5):1-10.

Nitrini R, Caramelli P, Herrera E Jr, Bahia VS, Caixeta LF, Radanovic M, Anghinah R, Charchat-Fichman H, Porto CS, Carthery MT, Hartmann AP, Huang N,Smid J, Lima EP, Takada LT, Takahashi DY. Incidence of dementia in a communitydwelling brazilian population. Alzheimer Dis Assoc Disord. 2004;18(4):241-46.

Nitrini R, Caramelli P, Bottino CM, Damasceno BP, Brucki SM, Anghinah R. Academia Brasileira de Neurologia. Diagnóstico de doença de Alzheimer no Brasil. Arq Neuropsiquiatr. 2005;63(3A):713-19.

Nunes CR, Bussab VSR, Guerra RF. Enriquecimento ambiente, privação social e manipulação neonatal. Revista de Ciências Humanas. 2003;34:365-94.

O'Keefe J, Nadel L. The hippocampus as a cognitive map. Oxford University Press; 1978.

Oddo S, Caccamo A, Shepherd JD, Murphy MP, Golde TE, Kayed R, Metherate R, Mattson MP, Akbari Y, LaFerla FM. Triple-transgenic model of Alzheimer's disease with plaques and tangles: intracellular Abeta and synaptic dysfunction. Neuron. 2003;39(3):409-21.

Oddo S, Vasilevko V, Caccamo A, Kitazawa M, Cribbs DH, LaFerla FM. Reduction of soluble Abeta and tau, but not soluble Abeta alone, ameliorates cognitive decline in transgenic mice with plaques and tangles. J Biol Chem. 2006;281(51):39413-23.

Oliver PY. El Enriquecimiento Ambiental en ratas: efectos diferenciales en función del sexo. Dissertação (Doutorado em Medicina). Bellaterra: Universitat Autônoma de Barcelona; 2007.

Pace GE. Optimization of immunohistochemical reactions. In: Immunohistochemical staining methods. 5th ed. Dako North America; 2009. Cap. 16. p. 109-114.

Palop JJ, Jones B, Kekonius L, Chin J, Yu GQ, Raber J, Masliah E, Mucke L. Neuronal depletion of calcium-dependent proteins in the dentate gyrus is tightly linked to Alzheimer's disease-related cognitive deficits. Proc Natl Acad Sci U S A. 2003;100(16):9572-7.

Pang TY, Hannan AJ. Enhancement of cognitive function in models of brain disease through environmental enrichment and physical activity. Neuropharmacology. 2013;64:515-28. 
Parra MA, Abrahams S, Fabi K, Logie R, Luzzi S, Della Sala S. Short-term memory binding deficits in Alzheimer's disease. Brain. 2009;132(Pt 4):1057-66.

Parsons CG, Stöffler A, Danysz W. Memantine: a NMDA receptor antagonist that improves memory by restoration of homeostasis in the glutamatergic system--too little activation is bad, too much is even worse. Neuropharmacology. 2007;53(6):699723.

Patil SS, Sunyer B, Höger H, Lubec G. Evaluation of spatial memory of C57BL/6J and CD1 mice in the Barnes maze, the Multiple T-maze and in the Morris water maze. Behav Brain Res. 2009;198(1):58-68.

Paxinos G, Franklin, KBJ. The mouse brain in stereotaxic coordinates. 3rd ed. San Diego: Academic Press; 2007.

Petrosini L, De Bartolo P, Foti F, Gelfo F, Cutuli D, Leggio MG, Mandolesi L. On whether the environmental enrichment may provide cognitive and brain reserves. Brain Res Rev. 2009;61(2):221-39.

Phillips RG, LeDoux JE. Differential contribution of amygdala and hippocampus to cued and contextual fear conditioning.Behav Neurosci. 1992;106(2):274-85.

Phinney AL, Calhoun ME, Wolfer DP, Lipp HP, Zheng H, Jucker M. No hippocampal neuron or synaptic bouton loss in learning-impaired aged beta-amyloid precursor protein-null mice. Neuroscience. 1999;90(4):1207-16.

Pilati N, Barker M, Panteleimonitis S, Donga R, Hamann M. A rapid method combining Golgi and Nissl staining to study neuronal morphology and cytoarchitecture. J Histochem Cytochem. 2008;56(6):539-50.

Pimplikar SW. Reassessing the amyloid cascade hypothesis of Alzheimer's Disease. Int J Biochem \& Cell Biol. 2009;41(6):1261-68.

Price JL, Morris JC. Tangles and plaques in nondemented aging and "preclinical" Alzheimer's disease. Ann Neurol. 1999;45(3):358-68.

Rampon C, Jiang CH, Dong H, Tang YP, Lockhart DJ, Schultz PG, Tsien JZ, Hu Y. Effects of environmental enrichment on gene expression in the brain. Proc Natl Acad Sci USA. 2000;97(23):12880-84.

Rebola N, Srikumar BN, Mulle C. Activity-dependent synaptic plasticity of NMDA receptors. J Physiol. 2010;588(Pt 1):93-9.

Redolat R, Mesa-Gresa P.Potential benefits and limitations of enriched environments and cognitive activity on age-related behaviouraldecline. Curr Top Behav Neurosci. 2012;10:293-316.

Reiserer RS, Harrison FE, Syverud DC, McDonald MP. Impaired spatial learning in the APPSwe + PSEN1DeltaE9 bigenic mouse model of Alzheimer's disease. Genes Brain Behav. 2007;6(1):54-65. 
Rhein V, Song X, Wiesner A, Ittner LM, Baysang G, Meier F, Ozmen L, Bluethmann H, Dröse S, Brandt U, Savaskan E, Czech C, Götz J, Eckert A. Amyloid-beta and tau synergistically impair the oxidative phosphorylation system in triple transgenic Alzheimer's disease mice. Proc Natl Acad Sci U S A. 2009;106(47):20057-62.

Riley KR, Snowdon DA, Desrosiers MF, Markesbery WR. Early life linguistic ability, late life cognitive function, and neuropathology: findings from the Nun Study. Neurobiol. Aging. 2005;26(3):341-47.

Roberson ED, Scearce-Levie K, Palop JJ, Yan F, Cheng IH, Wu T, Gerstein H, Yu GQ, Mucke L. Reducing endogenous tau ameliorates amyloid beta-induced deficits in an Alzheimer's disease mouse model. Science. 2007; 316(5825):750-4.

Roberson ED, Halabisky B, Yoo JW, Yao J, Chin J, Yan F, Wu T, Hamto P, Devidze N, Yu GQ, Palop JJ, Noebels JL, Mucke L. Amyloid-ß/Fyn-induced synaptic, network, and cognitive impairments depend on tau levels in multiple mouse models of Alzheimer's disease. J Neurosci. 2011;31(2):700-11.

Rodgers SP, Born HA, Das P, Jankowsky JL. Transgenic APP expression during postnatal development causes persistent locomotor hyperactivity in the adult. Mol Neurodegener. 2012;7:28.

Rosario ER, Chang L, Beckett TL, Carroll JC, Paul Murphy M, Stanczyk FZ, Pike CJ. Age-related changes in serum and brain levels of androgens in male Brown Norway rats. Neuroreport. 2009;20(17):1534-7.

Rossato JI, Bevilaqua LR, Medina JH, Izquierdo I, Cammarota M. Retrieval induces hippocampal-dependent reconsolidation of spatial memory. Learn Mem. 2006;13(4):431-40.

Saab BJ, Georgiou J, Nath A, Lee FJ, Wang M, Michalon A, Liu F, Mansuy IM, Roder JC. NCS-1 in the Dentate Gyrus Promotes Exploration, Synaptic Plasticity, and Rapid Acquisition of Spatial Memory. Neuron. 2009;63(5):643-56.

Saito S, Kobayashi S, Ohashi Y, Igarashi M, Komiya Y, Ando S. Decreased synaptic density in aged brains and its prevention by rearing under enriched environment as revealed by synaptophysin contents. J Neurosci Res. 1994;39(1):57-62.

Satler C, Tomaz C. Emotional working memory in Alzheimer's disease patients. Dement Geriatr Cogn Dis Extra. 2011;1(1):124-38.

Scarmeas N, Stern Y. Cognitive Reserve and Lifestyle. J Clin Exp Neuropsychol. 2003;25(5):625-33.

Scarmeas N, Zarahn E, Anderson KE, Habeck CG, Hilton J, Flynn J, Marder KS, Bell KL, Sackeim HA, Van Heertum RL, Moeller JR, Stern Y. Association of life activities with cerebral blood flow in Alzheimer disease: implications for the cognitive reservehypothesis. Arch Neurol. 2003;60(3):359-65. 
Schloesser RJ, Lehmann M, Martinowich K, Manji HK, Herkenham M. Environmental enrichment requires adult neurogenesis to facilitate the recovery from psychosocial stress. Molecular Psychiatry. 2010;15(12):1152-63.

Segovia G, Arco AD, Mora F. Environmental enrichment, prefrontal cortex, stress and aging of the brain. J. Neural Transm. 2009;116(8):1007-16.

Shankar GM, Bloodgood BL, Townsend M, Walsh DM, Selkoe DJ, Sabatini BL. Natural Oligomers of the Alzheimer Amyloid- $\beta \square$ Protein Induce Reversible Synapse Loss by Modulating an NMDA-Type Glutamate Receptor-Dependent Signaling Pathway. J Neurosci. 2007;27(11):2866-75.

Smith TD, Adams MM, Gallagher M, Morrison JH, Rapp PR. Circuit-specific alterations in hippocampal synaptophysin immunoreactivity predict spatial learning impairment in aged rats. J Neurosci. 2000;20(17):6587-93.

Snowdon DA, Kemper SJ, Mortimer JA, Greiner LH, Wekstein DR, Markesbery WR. Linguistic ability in early life and cognitive function and Alzheimer's disease in late life. Findings from the Nun Study. JAMA. 1996;275(7):528-32.

Stein TD, Anders NJ, DeCarli C, Chan SL, Mattson MP, Johnson JA. Neutralization of transthyretin reverses the neuroprotective effects of secreted amyloid precursor protein (APP) in APPSW mice resulting in tau phosphorylation and loss of hippocampal neurons: support for the amyloid hypothesis. J Neurosci. 2004;24(35):7707-17.

Stern Y, Habeck C, Moeller J, Scarmeas N, Anderson KE, Hilton HJ, Flynn $\mathrm{J}$, Sackeim H, van Heertum R. Brain Networks Associated with Cognitive Reserve in Healthy Young and Old Adults. Cereb Cortex. 2005;15(4):394-402.

Stern Y. Cognitive reserve and Alzheimer disease. Alzheimer Dis Assoc Disord. 2006;20(2):112-17.

Suh Y, Checler F. Amyloid Precursor Protein, Presenilins and $\alpha$-Synuclein: Molecular pathogenesis and pharmacological applications in Alzheimer's Disease. Pharmacol Rev. 2002;54(3):469-525.

Takeuchi A, Irizarry MC, Duff K, Saido TC, Hsiao Ashe K, Hasegawa M, Mann DM, Hyman BT, Iwatsubo T. Age-related amyloid beta deposition in transgenic mice overexpressing both Alzheimer mutant presenilin 1 and amyloid beta precursor protein Swedish mutant is not associated with global neuronal loss. Am J Pathol. 2000;157(1):331-9.

Terry AV Jr, Buccafusco JJ. The Cholinergic Hypothesis of Age and Alzheimer's DiseaseRelated Cognitive Deficits: Recent Challenges and Their Implications for Novel Drug Development. J Pharmacol Exp Ther. 2003;306(3):821-7.

Tomlinson BE, Blessed $G$, Roth $M$. Observations on the brains of nondemented old people. J Neurol Sci. 1968;7(2):331-56. 
Toth LA, Kregel K, Leon L, Musch TI. Environmental enrichment of laboratory rodents: the answer depends on the question. Comp Med. 2011;61(4):314-21.

Trinchese F, Fa' M, Liu S, Zhang H, Hidalgo A, Schmidt SD, Yamaguchi H, Yoshii $\mathrm{N}$, Mathews PM, Nixon RA, Arancio $O$. Inhibition of calpains improves memory and synaptic transmission in a mouse model of Alzheimer disease. J Clin Invest. 2008;118(8):2796-807.

van Loo PLP, Kruitwagen JM, Koolhaas JM, van de Weerd HA, van Zutphen LFM, Baumans V. Influence of cage enrichment on agressive behavior and physiological parameters in male mice. Appl Anim Behav Sci. 2002;76:65-81.

van Praag H, Kempermann G, Gage FH. Running increases cell proliferation and neurogenesis in the adult mouse dentate gyrus. Nature Neuroscience. 1999;2(3): 266-70.

van Praag H, Kempermann G, Cage FH. Neural consequences of environmental enrichment. Natures Review/Neuroscience. 2000;1(3):191-8.

Viel TA, Caetano AL, Albuquerque MS, Araujo MS, Buck HS.Chronic infusion of amyloid- $\beta$ peptide and sustained attention altered $\alpha 7$ nicotinic receptor density in the rat brain. Curr Alzheimer Res. 2012;9(10):1210-20.

von Bohlen und Halbach $\mathrm{O}$ and Unsicker $\mathrm{K}$. Morphological alterations in the amygdala and hippocampus of mice during ageing. Eur $\mathrm{J}$ Neurosci. 2002;16(12):2434-40.

von Bohlen und Halbach O, Zacher C, Gass P, Unsicker K. Age-related alterations in hippocampal spines and deficiencies in spatial memory in mice. $J$ Neurosci Res. 2006;83(4):525-31.

Wang JZ, Liu F. Microtubule-associated tau protein in development, degeneration and protection of neurons. Prog Neurobiol. 2008;10:1016-44.

Wang SH, Finnie PS, Hardt O, Nader K. Dorsal hippocampus is necessary for novel learning but sufficient for subsequent similar learning. Hippocampus. 2012;22(11):2157-70.

Wattmo C, Wallin AK, Minthon L. Functional response to cholinesterase inhibitor therapy in a naturalistic Alzheimer's disease cohort. BMC Neurol. 2012;12(1):134.

Weiskrantz L. Behavioral changes associated with ablation of the amygdaloid complex in monkeys. J Comp Physiol Psychol. 1956;49(4):381-91.

Whalley LJ, Deary IJ, Appleton CL, Starr JM. Cognitive reserve and the neurobiology of cognitive aging. Ageing Res Rev. 2004;3(4):369-82. 
Wolf SA, Kronenberg G, Lehmann K, Blankenship A, Overall R, Staufenbiel M, Kempermann G. Cognitive and Physical Activity Differently Modulate Disease

Progression in the Amyloid Precursor Protein (APP)-23 Model of Alzheimer's Disease. Biol Psychiatry. 2006;60:1314-23.

Wolfer DP, Stagljar-Bozicevic M, Errington ML, Lipp HP. Spatial Memory and Learning in Transgenic Mice: Fact or Artifact? News Physiol Sci. 1998;13:118-23.

Yoon SY, Choi JU, Cho MH, Yang KM, Ha H, Chung IJ, Cho GS, Kim DH. asecretase cleaved APP accumulates in cholinergic dystrophic neurites in normal, aged hippocampus. Neuropathol Appl Neurobiol. 2013 Feb 18. [Epub ahead of print].

Zelikowsky M, Bissiere S, Fanselow MS. Contextual fear memories formed in the absence of the dorsal hippocampus decay across time. J Neurosci. 2012; 32(10):3393-7.

Zola-Morgan S, Squire LR, Alvarez-Royo P, Clower RP. Independence of memory functions and emotional behavior: separate contributions of the hippocampal formation and the amygdala. Hippocampus. 1991;1(2):207-20. 